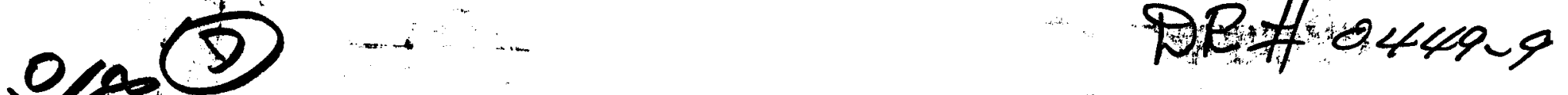

ORNL/CON-254

OAK RIDGE NATIONAL LABORATORY

MARTIN MARIETRA
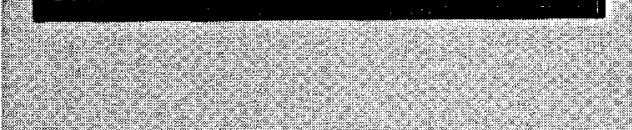

OPERATED BY

MARIIN MARIETTA ENERGY SYSTEMS, INC.

FOR THE UNITED STATES

DEPARTMENT OF ENERGY

\title{
Conservation and Renewable Energy Program Bibliography
}

\section{DO NOT MICROFILM COVER




\section{DISCLAIMER}

This report was prepared as an account of work sponsored by an agency of the United States Government. Neither the United States Government nor any agency Thereof, nor any of their employees, makes any warranty, express or implied, or assumes any legal liability or responsibility for the accuracy, completeness, or usefulness of any information, apparatus, product, or process disclosed, or represents that its use would not infringe privately owned rights. Reference herein to any specific commercial product, process, or service by trade name, trademark, manufacturer, or otherwise does not necessarily constitute or imply its endorsement, recommendation, or favoring by the United States Government or any agency thereof. The views and opinions of authors expressed herein do not necessarily state or reflect those of the United States Government or any agency thereof. 


\section{DISCLAIMER}

Portions of this document may be illegible in electronic image products. Images are produced from the best available original document. 
Printed in the United States of America. Available from
National Technical Information Service

U.S. Department of Commerce

5285 Port Royal Road, Springfield, Virginia 22161

NTIS price codes-Printed Copy: A05 Microfiche A01

This report was prepared as an account of work sponsored by an agency of the United States Government. Neither the United States Government nor any agency thereof, nor any of their employees, makes any warranty, express or implied, or assumes any legal liability or responsibility for the accuracy, completeness, or usefulness of any information, apparatus, product, or process disclosed, or represents that its use would not infringe privately owned rights. Reference herein to any specific commercial product, process, or service by trade name, trademark, manufacturer, or otherwise, does not necessarily constitute or imply its endorsement, recommendation, or favoring by the United States Government or any agency thereof. The views and opinions of authors expressed herein do not necessarily state or reflect those of the United States Government or any agency thereot.

\section{DO NOT MICROFILM

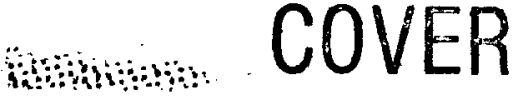


DE88 008992

CONSERVATION AND RENEWABLE ENERGY PROGRAM

\section{BIBLIOGRAPHY}

1988 Edition

Compiled by

Kathi H. Vaughan

for

Roger S. Carlsmith

Program Director

Date Published-April 1988

Prepared by the

Oak Ridge National Laboratory

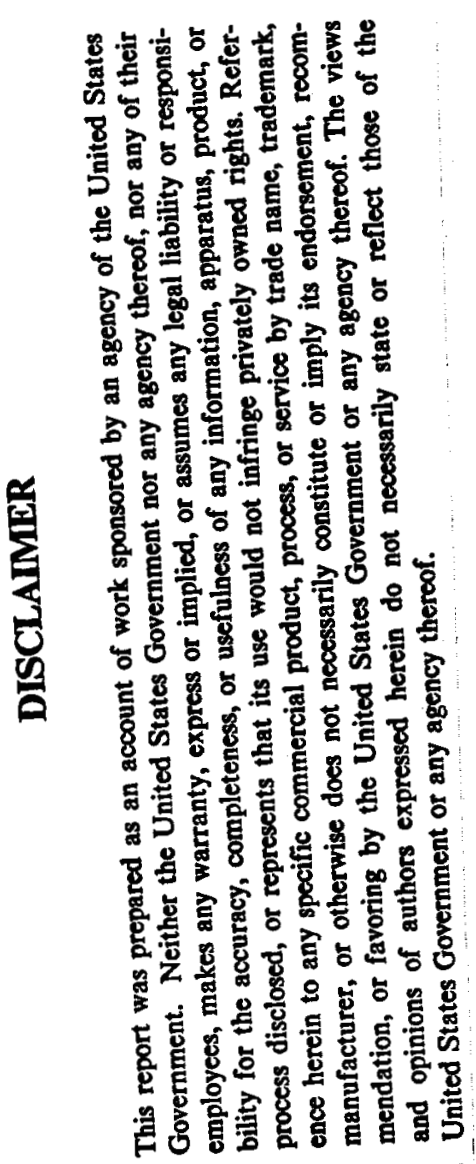

Oak Ridge, Tennessee 37831

operated by

MARTIN MARIETTA ENERGY SYSTEMS, INC.

for the

U.S. DEPARTMENT OF ENERGY

under contract DE-AC05-840R21400

MASTER

DISTRIBUTION OF THIS DOCUMENT IS UNLIMITEB 
Weine 
PREFACE ................... ANALYSIS AND EVALUATION. . . . . . . . . . . . . 1 BUILDING EQUIPMENT RESEARCH . . . . . . . . . . 10 BUILDING THERMAL ENVELOPE SYSTEMS AND MATERIALS . . 18 COMMUNITY SYSTEMS AND COGENERATION . . . . . . . . 26 RESIDENTIAL CONSERVATION SERVICE. . . . . . . . . . . 29 RETROFIT RESEARCH $\ldots \ldots \ldots \ldots \ldots$ CERAMIC TECHNOLOGY FOR ADVANCED HEAT ENGINES $\ldots 33$ ALTERNATIVE FUELS UTILIZATION . . . . . . . . . . 39 MICROEMULSION FUELS . . . . . . . . . . . . . . . . . 42 INDUSTRIAL CHEMICAL HEAT PUMPS $\ldots \ldots \ldots$ MATERIALS FOR WASTE HEAT UTILIZATION . . . . . . . 45 ENERGY CONVERSION AND UTILIZATION TECHNOLOGIES-MATERIALS . . . . . . . . . . 47 ENERGY CONVERSION AND UTILIZATION TECHNOLOGIES-TRIBOLOGY . . . . . . . . . . . 50 EMERGENCY ENERGY CONSERVATION . . . . . . . . . 51 ENERGY RELATED INVENTIONS PROGRAM. . . . . . . . . . 52 ELECTRIC ENERGY SYSTEMS . . . . . . . . . . . . . . . 53 THERMAL ENERGY STORAGE . . . . . . . . . . . 59 BIOFUELS PRODUCTION . . . . . . . . . . . 63 BIOTECHNOLOGY. . . . . . . . . . . . 66 SOLAR TECHNOLOGY. . . . . . . . . . . 70 GEOTHERMAL ................... 72 CONTINUOUS CHROMATOGRAPHY IN MULTICOMPONENT SEPARATIONS . . . . . . . . . . . . . . . . . 73 AUTHOR INDEX . . . . . . . . . . . . . . . . . . 75 


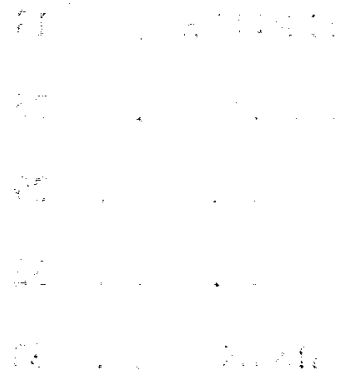




\section{PREFACE}

This bibliography covers reports and papers issued by the ORNL Conservation and Renewable Energy Program from 1980 through February 1988. Those documents designated by an asterisk (*) are available at ORNL. Single copies can be requested by writing or calling Kathi Vaughan at the address given below. Those documents designated by a dagger $(\dagger)$ are no longer available at ORNL but can be purchased from the National Technical Information Service (address given below) or obtained directly from the publisher, or from libraries or other information service.

Kathi H. Vaughan

Conservation and Renewable Energy Program

Oak Ridge National Laboratory

Building 4500N, MS 188

P. O. Box 2008

Oak Ridge TN 37831

(615) 574-5204

National Technical Information Service

U.S. Department of Commerce

5285 Port Royal Road

Springfield VA 22151

*Document available at ORNL

tDocument available from the National Technical Information Service or other source 


\section{ANAL YSIS AND EVALUATION}

1 E. A. Hirst, Analysis of Single-Family Home Characteristics and Energy Use in Minnesota, Minnesota Energy Agency (January 1980) ${ }^{\dagger}$

2 E. A. Hirst, "Conference Reports: Energy Conservation-The New Professionalism," Energy Policy 8(1) (March 1980) ${ }^{\dagger}$

3 G. Kulp et al., Regional Analysis of Highway Energy Use, ORNL-5587 (April $1980)^{\dagger}$

4 W. S. Johnson and F. E. Pierce, Energy and Cost Analysis of Commercial Building Shell Characteristics and Operating Schedules, ORNL/CON-39 (April 1980) ${ }^{\dagger}$

5 R. U. Ayres and J. W. Ayres (Variflex Corp.), Worldwide Transportation/Energy Demand, 1975-2000, Revised Variflex Model Projections, ORNL/Sub-79/45740/1 (April $1980)^{\dagger}$

6 D. L. Greene, "The Spatial Dimension of Gasoline Demand," Geographical Survey IX(2), pp. 19-28 (April 1980) ${ }^{\dagger}$

7 J. L. Blue, Intercity Trucking, ORNL-5507 (April 1980) ${ }^{\dagger}$

8 E. A. Hirst and P. Lazare, Evaluation of a Computerized Home Energy Audit Program in Minnesota, Minnesota Energy Agency (June 1980) ${ }^{\dagger}$

9 E. A. Hirst, "Review of Data Related to Energy Use in Residential and Commercial Buildings," Management Science 26(9) (September 1980) ${ }^{\dagger}$

10 G. Kulp et al., Transportation Energy Conservation Data Book, ORNL-5654, 4th edition (September 1980) ${ }^{\dagger}$

11 A. Fox, H. D. Nguyen and B. Thomas, Projections of Energy Use in Agricultural Production by Fuel Type and at the State Level, ORNL/CON-54 (September 1980) ${ }^{\dagger}$

12 E. A. Hirst and J. Armstrong, "Managing State Energy Conservation Programs: The Minnesota Experience," Science 210(4471) (November 1980) ${ }^{\dagger}$

13 E. A. Hirst, "Evaluating Energy Conservation Outreach Programs: A Case Study in Minnesota," Energy 5(12) (December 1980) ${ }^{\dagger}$

14 E. A. Hirst, "Energy Use in Minnesota Institutional Buildings," Energy Systems and Policy 4(4) (December 1980) ${ }^{\dagger}$

15 J. L. Blue and J. T. Arehart, A Pocket Reference of Energy Facts and Figures, Oak Ridge National Laboratory (December 1980) ${ }^{\dagger}$

16 E. A. Hirst, R. Maier and M. Patton, "Evaluation of Telephone Energy Conservation Information Centers in Minnesota," J. Environ. Syst. 10, pp. 229-48 (1981) ${ }^{\dagger}$ 
17 J. N. Hooker, Oil Pipeline Energy Consumption and Efficiency, ORNL-5697 (January 1981) ${ }^{\dagger}$

18 S. M. Cohn et al, A Commercial Energy Use Model for the Ten U. S. Federal Regions, ORNL/CON-40 (March 1981) ${ }^{\dagger}$

19 L. G. Berry et al., Review of Evaluations of Utility Home Energy Audit Programs, ORNL/CON-58 (March 1981)

20 G. Samuels, Transportation Energy Requirements to the Year 2010, ORNL-5745 (April 1981) ${ }^{\dagger}$

21 D. L. O'Neal, K. R. Corum and J. L. Jones, An Estimate of Consumer Discount Rates Implicit in Single-Family Housing Construction Practices, ORNL/CON-62 (April 1981) ${ }^{\dagger}$

22 J. L. Blue and E. A. Hirst, Disaggregate Energy Consumption Data: Federal/State Cooperation, ORNL/CON-72 (May 1981) ${ }^{\dagger}$

23 E. A. Hirst, J. Carney and P. Knight, Energy Use at Institutional BuildingsDisaggregate Data and Data Management Issues, ORNL/CON-73 (June 1981) ${ }^{\dagger}$

24 E. A. Hirst et al., Evaluation of Conservation Programs: A Primer, ORNL/CON-76 (July 1981) ${ }^{\dagger}$

25 E. A. Hirst et al., Analysis of Energy Audits at 48 Hospitals, ORNL/CON-77 (July 1981) ${ }^{\dagger}$

26 E. A. Hirst, J. Trimble and R. T. Goeltz, Analysis of Energy Use at U. S. Institutional Buildings, ORNL/CON-78 (November 1981) ${ }^{\dagger}$

27 E. J. Soderstrom, L. G. Berry and E. A. Hirst, "The Use of Metaevaluation to Plan Evaluations of Conservation Programs," Evaluation and Policy Planning 4, pp. 113-22 (November 1981) ${ }^{\dagger}$

28 E. A. Hirst et al., Energy Use from 1973 to 1980: The Role of Improved Energy Efficiency, ORNL/CON-79 (December 1981) ${ }^{\dagger}$

29 S. Grady and E. A. Hirst, Evaluation of Utility Home Energy Audit Programs: A Wisconsin Example, ORNL/CON-88 (March 1982) ${ }^{\dagger}$

30 D. L. Greene et al., Transportation Energy Use 1973-80: Changes, Trends, and Causes, ORNL/TM-7953 (April 1982) ${ }^{\dagger}$

31 S. C. Kurzius and R. W. Barnes, Coal-Fired Boiler Costs for Industrial Applicátions, ORNL/CON-67 (April 1982) ${ }^{\dagger}$

32 L. M. Bronfman et al., Evaluation of the Energy-Related Inventions Program, Vol. II: Case Studies of Supported Projects, ORNL/CON-92/V2 (May 1982) ${ }^{\dagger}$ 
33 E. A. Hirst, W. Fulkerson, R. S. Carlsmith and T. J. Wilbanks, "Improving Energy Efficiency: The Effectiveness of Government Action," Energy Policy 10, pp. 131-42 (June 1982) ${ }^{\dagger}$

34 Charles River Associates, An Analysis of the Residential Energy Conservation Tax Credits: Concepts and Numerical Estimates, ORNL/Sub-80/13816/1 (June 1982) ${ }^{\dagger}$

35 E. A. Hirst, R. T. Goeltz and H. Manning, Household Retrofit Expenditures and the Federal Residential Energy Conservation Tax Credit, ORNL/CON-95 (June 1982) ${ }^{\dagger}$

36 E. A. Hirst et al., Evaluation Plan for the Bonneville Power Administration Residential Energy Conservation Programs, Vol. 1, ORNL/CON-94 (July 1982)

37 D. B. Reister, J. A. Edmonds and R. W. Barnes, The Oak Ridge Industrial Model Volume I-Overview, ORNL/CON-56/V1 (August 1982) ${ }^{\dagger}$

38 D. B. Reister, J. A. Edmonds and R. W. Barnes, The Oak Ridge Industrial Model Volume II-Model Description, ORNL/CON-56/V2 (August 1982) ${ }^{\dagger}$

39 D. B. Reister, J. A. Edmonds and R. W. Barnes, The Oak Ridge Industrial Model Volume III-Data Base Description, ORNL/CON-56/V3 (August 1982) ${ }^{\dagger}$

40 S. M. Cohn and N. S. Cardell, Residential Energy Tax Credit Eligibility: A Case Study for the Heat Pump Water Heater, ORNL/CON-71 (September 1982) ${ }^{\dagger}$

41 G. Kulp, H. J. Tsao and R. E. Webber, An Evaluation of Ridesharing Programs in Michigan, ORNL/CON-99 (October 1982) ${ }^{\dagger}$

42 G. Kulp and M. C. Holcomb, Transportation Energy Data Book, 6th Edition, ORNL-5883 (October 1982) ( $^{\dagger}$

43 D. L. Greene et al., Estimating the Total Impact on Energy Consumption of Department of Energy Conservation Programs, ORNL-5925 (November 1982) ${ }^{\dagger}$

44 F. J. Zehr et al., The Performance and Economics of Residential Solar Space Heating, ORNL/CON-70 (November 1982) ${ }^{\dagger}$

45 L. G. Berry, The Role of Financial Incentives in Utility-Sponsored Residential Conservation Programs: A Review of Customer Surveys, ORNL/CON-102 (December 1982) ${ }^{\dagger}$

46 D. L. Greene and C. K. Chen, "A Time Series Analysis of State Gasoline Demand, 1975-80," The Professional Geographer 35(1), pp. 40-51 (February 1983) ${ }^{\dagger}$

47 M. G. Rorke, L. M. Bronfman and E. J. Soderstrom, Evaluation of the EnergyRelated Inventions Program Volume 1: Analysis of Case Studies of Supported Projects, ORNL/CON-92/V1 (February 1983) ${ }^{\dagger}$ 
48 E. A. Hirst et al., Methods to Deal with Self-Selection in Estimating Conservation Program Energy Savings: Use of Synthetic Data to Test Alternative Approaches, ORNL/CON-120 (March 1983) ${ }^{\dagger}$

49 N. E. Collins, L. N. McCold and P. Zuschneid, Thermal Efficiency Standard Codes, Vol. 1: State-of-the-Art Literature Review and Analysis of Secondary Data, ORNL/CON-101/V1 (June 1983) ${ }^{\dagger}$

50 E. A. Hirst et al., Evaluation of the BPA Residential Weatherization Pilot Program, ORNL/CON-124 (June 1983) ${ }^{\dagger}$

51 N. E. Collins, J. H. Reed and R. B. Braid, A Systematic Review of Approaches to Assessing Energy Conservation Program (SECP and EES) Impacts, ORNL/TM-8771 (July 1983) ${ }^{\dagger}$

52 L. G. Berry, H. Tsao and E. A. Hirst, Design Options to Test the Effects of Financial Incentives in a Utility Conservation Program: TVA's Heat Pump Water Heater Program, ORNL/CON-125 (August 1983) ${ }^{\dagger}$

53 L. F. Menendez, Residential Energy Conservation Programs in Minnesota: The Northern States Power Experience, ORNL/CON-127 (August 1983) ${ }^{\dagger}$

54 E. J. Soderstrom, L. M. Bronfman and M. L. Rorke, The Energy-Related Inventions Program-An Overview of the Evaluation, ORNL/CON-92/V3 (September 1983) ${ }^{\dagger}$

55 E. A. Hirst and P. S. Hu, The Residential Conservation Service in Connecticut: Evaluation of the CONN SAVE Program, ORNL/CON-132 (September 1983) ${ }^{\dagger}$

56 D. I. Lerman, B. H. Bronfman and B. E. Tonn, Process Evaluation of the Bonneville Power Administration Residential Weatherization Pilot Program, ORNL/CON-138 (October 1983) ${ }^{\dagger}$

57 G. F. Roberts and D. L. Greene, Trends in Heavy Truck Energy Use and Efficiency, ORNL/TM-8843 (October 1983) ${ }^{\dagger}$

58 E. A. Hirst, D. White and R. T. Goeltz, Comparison of Actual Electricity Savings with Audit Predictions in the BPA Residential Weatherization Pilot Program, ORNL/CON-142 (November 1983) ${ }^{\dagger}$

59 E. A. Hirst et al., Evaluation of Home Energy Audit and Retrofit Loan Programs in Minnesota: The Northern States Power Experience, ORNL/CON-136 (December 1983) ${ }^{\dagger}$

60 E. A. Hirst, D. White and R. T. Goeltz, Energy Savings Due to the BPA Residential Weatherization Pilot Program Two Years After Participation, ORNL/CON-146 (January 1984) ${ }^{\dagger}$

61 L. G. Berry and B. E. Tonn, Loan Impacts in Home Energy Audit Programs: A Minnesota Example, ORNL/CON-145 (February 1984) ${ }^{\dagger}$ 
62 E. A. Hirst and R. T. Goeltz, Comparison of Actual and Predicted Energy Savings in Minnesota Gas-Heated Single-Family Homes, ORNL/CON-147 (March 1984) ${ }^{\dagger}$

63 M. C. Holcomb and S. Koshy, Transportation Energy Data Book: Edition 7, ORNL-6050 (June 1984) ${ }^{\dagger}$

64 B. E. Tonn, E. A. Hirst and E. Holub, Use of Evaluation Data to Develop a Low Cost Monitoring System for the BPA Residential Weatherization Program, ORNL/CON-181 (June 1984)

65. D. I. Lerman and B. H. Bronfman, Process Evaluation of the Bonneville Power Administration Interim Residential Weatherization Program, ORNL/CON-158 (August 1984) ${ }^{\dagger}$

66 E. A. Hirst, R. Goeltz and D. White, Use of Electric Billing Data to Determine Household Energy Use Fingerprints, ORNL/CON-164 (August 1984) ${ }^{\dagger}$

67 P. S. Hu, D. L. Greene and L. E. Till, Motor Vehicle MPG and Market Shares Report: First Six Months of Model Year 1984, ORNL/TM-9391 (October 1984) ${ }^{\dagger}$

68 T. A. Vineyard et al., Analysis of Post Audit Energy Data at 41 Hospitals, ORNL/CON-165 (October 1984) ${ }^{\dagger}$

69 D. L. Greene, "Estimating Daily Vehicle Usage Distributions and the Implications for Limited-Range Vehicles," Transportation Research 19B(4), pp. 347-58 (1985) ${ }^{\dagger}$

70 P. S. Hu and M. C. Holcomb, Motor Vehicle MPG and Market Shares Report: Model Year 1984, ORNL/TM-9489 (January 1985) ${ }^{\dagger}$

71 E. A. Hirst, D. White and R. Goeltz, Three Years After Participation: Electricity Savings Due to the BPA Residential Weatherization Pilot Program, ORNL/CON-166 (January 1985) ${ }^{\dagger}$

72 E. Holub, Residential and Commercial Energy Demand Models: Review and Agenda for Improvement, ORNL/CON-169 (January 1985) ${ }^{\dagger}$

73 N. E. Collins et al., Past Efforts and Future Directions for Evaluating State Energy Conservation Programs, ORNL-6113 (April 1985) ${ }^{\dagger}$

74 F. Southworth, DOE National Rideshare Program Plan, ORNL/TM-9608 (May 1985) ${ }^{\dagger}$

75 R. N. McGill, J. N. Hooker and J. W. Hodgson, Fuel Consumption and Emission Values for Traffic Models, FHWA/RD85/053 (Federal Highway Administration, May $1985)^{\dagger}$

76. B. Tonn, E. A. Hirst and E. Holub, Use of Evaluation Data to Develop a Low-Cost Monitoring System for the BPA Residential Weatherization Program, ORNL/CON181 (June 1985)

77 E. A. Hirst et al., Evaluation of the BPA Residential Weatherization Program, ORNL/CON-180 (June 1985) ${ }^{\dagger}$ 
78 P. S. Hu, Motor Vehicle MPG and Market Shares Report: First Six Months of Model Year 1985, ORNL/TM-9631 (June 1985) ${ }^{\dagger}$

79 E. A. Hirst and D. White, Indoor Temperature Changes After Retrofit: Inferences Based on Electricity Billing Data for Nonparticipants and Participants in the BPA Residential Weatherization Program, ORNL/CON-182 (July 1985) ${ }^{\dagger}$

80 E. A. Hirst et al., Actual Electricity Savings for Homes Retrofit by the BPA Residential Weatherization Program, ORNL/CON-185 (July 1985) ${ }^{\dagger}$

81 M. A. Brown et al., A Strategy for Accelerating the Use of Energy Conserving Building Technologies, ORNL/TM-9630 (July 1985)

82 M. A. Brown and G. Reeves, The Implementation of a Residential Energy Conservation. Shared Savings Program: The General Public Utilities Experience, ORNL/CON-187 (July 1985) ${ }^{\dagger}$

83 E. A. Hirst and K. Keating, "Dynamic Effects of Utility Energy Conservation Programs: A Residential Retrofit Program Example," Second National Conference on Energy Conservation Program Evaluation: Practical Methods, Useful Results, Chicago (August 1985) ${ }^{\dagger}$

84 T. A. Vineyard, Review of the 50/50 Programs to Improve Energy Efficiency of Existing Homes, ORNL/CON-184 (August 1985) ${ }^{\dagger}$

85 E. Hirst and R. Goeltz, Potential vs Practice: Installation of Retrofit Measures in the Hood River Conservation Project, ORNL/CON-189 (August 1985) ${ }^{\dagger}$

86 C. M. Hanchey and M. C. Holcomb, Transportation Energy Data Book: Edition 8, ORNL-6205 (November 1985) ${ }^{\dagger}$

87 R. N. McGill and M. C. Holcomb, Data Source Compendium of Non-Residential Transportation Energy Use, ORNL/TM-9329 (November 1985) ${ }^{\dagger}$

88 Eric Hirst et al., Energy Efficiency in Buildings: Progress and Promise, ed. F. M. O'Hara, Jr. (Washington, D.C.: American Council for an Energy-Efficient Economy, 1986) ${ }^{1}$

89 B. Tonn, E. Holub and M. Hilliard, The Bonneville Power Administration Conservation/Load/Resource Modeling Process: Review, Assessment, and Suggestions for Improvement, ORNL/CON-190 (January 1986)*

90 P. S. Hu, Motor Vehicle MPG and Market Shares Report: Model Year 1985, ORNL/TM-9909 (February 1986)*

91 L. Berry, The Role of Evaluation Results in the Bonneville Power Administration's Conservation Assessment and Demand Forecasting Models: Present Uses and Future Directions, ORNL/CON-197 (February 1986)*

\footnotetext{
${ }^{1}$ Suite 535, 1001 Connecticut Avenue, N. W., Washington, D. C. 20036 .
} 
Analysis and Evaluation

92 E. A. Hirst, Electric Utility Demand Side Programs and Integrated Resource Planning: Visits to Ten Utilities, ORNL/CON-195 (March 1986)*

93 R. Goeltz, E. A. Hirst and D. Trumble, Electricity Savings One to Three Years After Participation in the BPA Residential Weatherization Program, ORNL/CON-194 (April 1986)*

94 E. Hirst and R. Goeltz, Electricity Use for Residential Space Heating: Comparison of the Princeton Scorekeeping Method with End-Use Load Data, ORNL/CON-203 (April 1986)*

95 D. L. Greene, Driver Energy Conservation Awareness Training: Review and Recommendations for a National Program, ORNL/TM-9897 (May 1986)*

96 R. Goeltz and E. Hirst, Residential Retrofit Measures in the Hood River Conservation Project: Recommendations, Installations, and Barriers, ORNL/CON-208 (June 1986)*

97 V. Kreitler (Synergic Resources Corp.), Alternative Utility Conservation Program Designs: An Evaluation Based on Case Study Program Experience, ORNL/Sub/8405906/1 (June 1986)*

98 E. Hirst and R. Goeltz, Dynamics of Participation and Supply of Services in the Hood River Conservation Project, ORNL/CON-210 (July 1986)*

99 M. A. Brown et al., Technology Transfer for DOE's Office of Buildings and Community Systems: Assessment and Strategies, ORNL/CON-202 (July 1986)*

100 T. M. Dinan, An Analysis of the Methodology Used to Incorporate Price-Induced Conservation into BPA's Planning Process, ORNL/CON-211 (July 1986)*

101 G. Gillette (American Institute of Architects Foundation) and M. A. Brown, Occupant Evaluation of Commercial Office Lighting: Volume 1, Methodology and Bibliography, ORNL/TM $\rightarrow$ 10264/VI (November 1986)*

102 B. Tonn and D. White, Residential Wood Use in the Pacific Northwest: 1979-1985, ORNL/CON-216 (December 1986)*

103 P. S. Hu and L. E. Till, User's Manual. Oak Ridge National Laboratory MPG and Market Shares Data System, ORNL-6309 (December 1986)*

104 D. Prowler, E. Johnson. Mohler, and M. Aseltine, Inventory of Energy Research in School of Architecture 1972-1985, ORNL/Sub/84-89680/1 (January 1987)*

105 Consumer Energy Council of America Research Foundation, $A$ Comparative Analysis of Utility-and Non-Utility-Based Energy Service Companies: A Case Study Approach, ORNL/Sub/84-19701/1 (January 1987)*

106 P. S. Hu and L. S. Buckels, Motor Vehicle MPG and Market Shares Report: Model Year 1986, ORNL-6351 (February 1987)* 
107 M. A. Brown and D. L. White, Impact Analysis of a Residential Energy Conservation Shared Savings Program: The General Public Utilities Experience, ORNL/CON217 (February 1987)*

108 L. Berry et al., Evaluation of Gas Heating System Retrofit Pilot Programs in Kentucky and Minnesota, ORNL/CON-229 (March 1987)*

109 E. Hirst, R. Goeltz, and D. Trumble, Electricity Use and Savings in the Hood River Conservation Project, ORNL/CON-231 (April 1987)*

110 P. C. Stern et al., "Answering Behavioral Questions about Energy Efficiency in Buildings," Energy 12(5), pp. 339-53 (May 1987) ${ }^{\dagger}$

111 E. Hirst, "Electric Utility Energy Conservation and Load Management Programs: Current Activities at Ten Utilities," Electric Potential 3(3), pp. 20-32 (May-June 1987) $)^{\dagger}$

112 B. E. Tonn, R. T. Goeltz and S. Purucker, Expert Systems and Microwave Communication Systems Alarms Processing: A Feasibility Study, ORNL/TM-10429 (July 1987)*

113 G. Gillette, Occupant Evaluation of Commercial Office Lighting: Volume 3, Data Archive and Database Management System, ed. M. A. Brown, ORNL/TM-10264/V3 (August 1987)*

114 H. G. Peach and E. A. Hirst, "Evaluation Design: Factors in the Organization of Evaluation as an Extension of the Theory of Evaluation Design," Proceedings of the 1987 Conference on Energy Conservation Program Evaluation: Practical Methods, Useful Results 2, pp. 283-94 (August 1987) ${ }^{\dagger}$

115 B. E. Tonn and D. L. White, Use of Wood for Space Heating: Analysis of Hood River Conservation Project Submetered Homes, ORNL/CON-234 (September 1987)*

116 T. M. Dinan, An Analysis of the Impact of Residential Retrofits on Indoor Temperature Choice, ORNL/CON-236 (October 1987)*

117 M. A. Brown, D. L. White and S. L. Purucker, Impact of the Hood River Conservation Project on Electricity Use for Residential Water Heating, ORNL/CON238 (October 1987)*

118 T. K. Stovall, Hood River Conservation Project Load Analysis, ORNL/CON-240 (November 1987)*

119 R. W. Marans and M. A. Brown, Occupant Evaluation of Commercial Office Lighting: Volume II, Preliminary Data Analysis, ORNL/TM-10264/V2 (November 1987)*

120 E. Hirst, Regulatory Responsibility for Utility Integrated Resource Planning, ORNL/CON-249 (January 1988)*. 
121 E. A. Hirst and C. Knutsen, Developing an Integrated Planning. Process: An Electric Utility Case Study, ORNL/CON-247 (January 1988)*

122 Eric Hirst, Marginal-Cost-of-Service Analysis: A Powerful Marketing Tool for Electric Utilities, ORNL/CON-251 (February 1988)* 


\section{BUILDING EQUIPMENT RESEARCH}

123 A. A. Domingorena, F. A. Creswick and S. J. Ball, Performance Evaluation of $a$ Selected 3-Ton Air-to-Air Heat Pump in the Heating Mode, ORNL/CON-34 (January $1980)^{\dagger}$

124 Consolidated Natural Gas Service Company, Inc., A High Seasonal Performance Factor Gas Heat Pump for the North Central U.S. (January 1980) ${ }^{\dagger}$

125 C. A. Wan (National Bureau of Standards), Energy Test Method Development for Electric Heat-Pump Water Heaters, NBSIR 79-1951 (January 1980) ${ }^{\dagger}$

126 Arthur D. Little, Inc., Development of High Efficiency, Automatic Defrosting Refrigerator/Freezer, Phase 1-Design and Development, ORNL/Sub-7255/1 (February 1980 $)^{\dagger}$

127 Arthur D. Little, Inc., Development of a High Efficiency, Automatic Defrosting Refrigerator/Freezer, Final Report, ORNL/Sub-7255/2 (February 1980) ${ }^{\dagger}$

128 D. P. DeWitt and M. V. Peart, Bi-Radiant Oven, A Low Energy Oven System, Vol. 1-Development and Assessment, ORNL/Sub-80/0082/1 (April 1980) ${ }^{\dagger}$

129 W. P. Levins, Energy and the Laundry Process, ORNL/CON-41 (April 1980) ${ }^{\dagger}$

130 A. D. Vasilakis et al. (Advanced Mechanical Technology, Inc.), Research and Development of a High Efficiency Gas-Fired Water Heater, Vol. 1, Final Report Summary, ORNL/Sub-7381/1 and Vol. 2, Task Reports, ORNL/Sub-7381/2 (May $1980)^{\dagger}$

131 A. S. Holman and L. A. Abbatiello, Annual Cycle Energy System Performance Report November 1977 through September 1978, ORNL/CON-42 (May 1980) ${ }^{\dagger}$

132 E. A. Nephew, L. A. Abbatiello and M. L. Ballou, Theory and Design of an Annual Cycle Energy System for Residences, ORNL/CON-43 (May 1980) ${ }^{\dagger}$

133 Honeywell, Inc., Economic Evaluation of the Annual Cycle Energy System-Final Report, Vol. 1, Executive Summary, ORNL/Sub-7470/1-V1 and Vol. 2, Detailed Results, ORNL/Sub-7470/1-V2 (May 1980) ${ }^{\dagger}$

134 L. A. Abbatiello, "The ACES Characteristics and Performance," Proceedings of the International Congress on Buildings and Energy Management, Povoa de Varzim, Portugal, May 12-16, 1980 (Pergamon Press, Ltd., 1980) ${ }^{\dagger}$

135 R. E. Minturn et al., ACES 1979 Capabilities and Potential, ORNL/CON-48 (June 1980 ${ }^{\dagger}$

136 V. D. Baxter, Ice-Maker Heat Pump Development, Final Report, ORNL/CON-50 (September 1980) ${ }^{\dagger}$ 
137. Energy Utilization Systems, Inc., Demonstration of a Heat-Pump Water Heater, Vol. 1-Design Report, ORNL/Sub-7321/3 (December 1980)

138 National Water Well Association, Ground-Water Heat Pumps: An Examination of Hydrogeologic, Environmental, Legal, and Economic Factors Affecting Their Use, DOE/CS $20060-5120$ Vols. 1 and 2 (January 1981) ${ }^{\dagger}$

139 National Bureau of Standards, A Study of an Integrated Appliance, the Air Conditioner/Heat Pump-Heat Recovery Unit Water Heater, NBSIR 80-2145 (February 1981)

140 M. L. Ballou, E. A. Nephew and L. A. Abbatiello, MAD: A Computer Program for ACES Design Using Monthly Thermal Loads, ORNL/CON-51 (March 1981) ${ }^{\dagger}$

141 U.S. DOE, Proceedings of the Conference on Waste Heat Recovery for Energy Conservation - Residential and Light Commercial Heat Pumps, Air Conditioning, and Refrigeration Systems, CONF-800966 (March 1981) ${ }^{\dagger}$

142 V. D. Baxter, ACES: Final Performance Report December 1, 1978 through September 15, 1980, ORNL/CON-64 (April 1981)

143 W. T. Lawrence and F. E. Ruccia (A. D. Little, Inc.), Development of Advanced Insulation for Appliances, Task :, ORNL/Sub-81/13800/1 (June 1981) ${ }^{\dagger}$

144 Energy Utilization Systems, Inc., Demonstration of a Heat Pump Water Heater, Vol. 2 Final Report, ORNL/Sub-7321/4 (June 1981) ${ }^{\dagger}$

145 J. L. Bledsoe and D. R. Miller, Data Collection and Processing for the ACES, ORNL/CON-59 (August 1981)*

146 W. P. Levins, Effect of Forced Ventilation on House Infiltration, ORNL/CON-75 (August 1981)

147 W. M. Toscano et al. (Foster-Miller Assoc., Inc.), Research and Development of Highly Energy-Efficient Supermarket Refrigeration Systems, Volume 1 - Executive Summary and Task Reports, ORNL/Sub/80-61601/1 (October 1981) ${ }^{\dagger}$

148 D. P. DeWitt and M. V. Peart (Purdue Univ.), Bi-Radiant Oven - A Low-Energy Oven System, Volume II-Executive Summary, ORNL/Sub/80-0082/2 (October 1981) ${ }^{\dagger}$

149 P. F. Launay (Univ. of Illinois), Improving the Efficiency of Refrigerators and Heat Pumps by Using a Nonazeotropic Mixture of Refrigerants, ORNL/Sub-81/7762/1 (October 1981)!

150 G. H. Alexander et al. (Battelle Columbus Labs), Development of Concepts for LowCost Energy Storage Assemblies for ACES Applications, ORNL/Sub-7800/1 (October 1981)

151 C. K. Rice et al., Design Optimization and the Limits of Steady-State Heating Efficiency for Conventional Single-Speed Air-Source Heat Pumps, ORNL/CON-63 (October 1981) ${ }^{\dagger}$ 
152 R. T. Nelson and P. W. MacCarthy (Columbus Products Co.), Research and Development of Energy-Efficient Appliances Motor Compressors, Final Report Vol. I - Executive Summary, ORNL/Sub-7229/1 (November 1981) ${ }^{\dagger}$

153 R. T. Nelson and P. W. MacCarthy (Columbus Products Co.), Research and Development of Energy-Efficient Appliances Motor Compressors, Final Report Vol. IIMarket Evaluation, ORNL/Sub-7229/2 (November 1981) ${ }^{\dagger}$

154 R. T. Nelson and P. W. MacCarthy (Columbus Products Co.), Research and Development of Energy-Efficient Appliances Motor Compressors, Final Report Vol.' IIIDevelopment and Field Test Plan, ORNL/Sub-7229/3 (November 1981) ${ }^{\dagger}$

155 S. K. Fischer and C. K. Rice, A Steady-State Computer Design Model for Air-toAir Heat Pumps, ORNL/CON-80 (December 1981) ${ }^{\dagger}$

156 M. H. Somerville and S. G. Penoncello, The Design and Development of a Split Evaporator Heat Pump System, ORNL/Sub-7434/1 (December 1981) ${ }^{\dagger}$

157 W. P. Levins, Estimated Seasonal Performance of a Heat Pump Water Heater Including Effects of Climate and In-House Location, ORNL/CON-81 (January 1982) ${ }^{\dagger}$

158 G. G. Scheitlin and D. P. DeWitt (Purdue Univ.), Bi-Radiant Oven, A Low Energy Oven System, Vol. II - Application and Transfer of the Technology, ORNL/Sub/80-0082/3 (March 1982) ${ }^{\dagger}$

159 W. F. Stoecker (Univ. of Illinois), Energy Characteristics of a Two-Evaporator Refrigerator Using a Refrigerant Mixture, ORNL/Sub/81-7762/1 (March 1982) ${ }^{\dagger}$

160 Westinghouse Electric Corp., Advanced Electric Heat Pump Market and Business Analysis - Final Report, ORNL/Sub/79-24712/1 (April 1982) ${ }^{\dagger}$

161 TRW, RD\&D Opportunities for Large Air Conditioning and Heat Pump SystemsFinal Report, ORNL/Sub/80-13817/1\&2 (June 1982) ${ }^{\dagger}$

162 AiResearch Manufacturing Company, Phase II Brayton/Rankine 10-Ton Gas-Fired Space Conditioning Systems - First Annual Technical Report, ORNL/Sub-80/24706/1 (July 1982) ${ }^{\dagger}$

163 D. P. DeWitt and M. V. Peart (Univ. of Illinois), Energy Characteristics of a TwoEvaporator Refrigerator Using a Refrigerant Mixture, ORNL/Sub/81-7762/2 (July 1982) ${ }^{\dagger}$

164 E. A. Nephew and L. A. Abbatiello, Performance and Economics of Eight Alternative Systems for Residential Heating, Cooling, and Water Heating in 115 U.S. Cities, ORNL/CON-89 (November 1982) ${ }^{\dagger}$

165 W. A. Miller, Laboratory Evaluation of the Heating Capacity and Efficiency of $a$ High-Efficiency, Air-to-Air Heat Pump with Emphasis on Frosting/Defrosting Operation, ORNL/CON-69 (December 1982) ${ }^{\dagger}$ 
166 Energy Utilization Systems, Inc., Examination and Life Assessment of Field-Tested Heat Pump Water Heaters, ORNL/Sub-7321/5 (December 1982) ${ }^{\dagger}$

167 E. A. Lawton et al. (Whittaker Corp.), Highly Efficient Commercial Pulse-Combustion Gas-Fired Water Heater - R\&D Report, ORNL/Sub/79-24711/2 (March 1983) ${ }^{\dagger}$

168 A. D. Vasilakis and J. Gerstmann (Advanced Mechanical Technology, Inc.), Development of a High-Efficiency Gas-Fired Water Heater Phase II - Production Prototype Design and Development - Executive Summary and Task Reports, ORNL/Sub/77-7381/3 (April 1983)

169 W. M. Toscano, D. H. Walker and R. D. Tetreault (Foster-Miller Assoc. Inc.), Research and Development of Highly Energy-Efficient Supermarket Refrigeration Systems - Vol. 2, Supplementary Laboratory Testing, ORNL/Sub/80-61601/2 (June 1983) ${ }^{\dagger}$

170 V. D. Baxter, ACES Tests at the TECH Site, 1981, ORNL/CON-96 (August 1983) ${ }^{\dagger}$

171 M. G. Middleton and R. S. Sauber, Research and Development of Energy-Efficient Appliance Motor-Compressors, Vol. IV - Production Demonstration and Field Test, ORNL/Sub/78-7229/4 (September 1983) ${ }^{\dagger}$

172 R. D. Fischer (Battelle Columbus Labs), Models of Simultaneous Heat and Moisture Transfer in Soils, ORNL/Sub/80-7800/1\&06 (October 1983) ${ }^{\dagger}$

173 Battelle Columbus Laboratory, State-of-the-Art Survey of Existing Knowledge for the Design of Ground-Source Heat Pumps, ORNL/Sub/80-7800/2\&06 (November 1983)

174 Arthur D. Little, Inc., Assessment of Internal Combustion Engines as Drivers for Heat Pumps: Final Report, ORNL/Sub/80-13836/1\&02 (January 1984) ${ }^{\dagger}$

175 S. E. Veyo and T. J. Fagan (Westinghouse), Advanced Electric Heat Pump DualStroke Compressor and System Development, Final Report, ORNL/Sub/79-24712/3 (December 1983)

176 S. E. Veyo (Westinghouse), Advanced Electric Heat Pump Component Development and Evaluation, Interim Report, ORNL/Sub/79-24712/2 (January 1984) ${ }^{\dagger}$

177 R. D. Fischer and G. H. Strickford, Jr. (Battelle Columbus Labs), Technical and Economic Feasibility of Horizontal, Multiple Shallow-Well, and Deep-Well Ground Coupling for Residential Heat Pump Applications: "Final Report, ORNL/Sub/80-7800/3\&06 (January 1984) ${ }^{\dagger}$.

178 S. Johnson et al. (Univ. of Tenn.), TECH House/Horizontal Coil Ground Coupled Heat Pump: 1982-83 Heating Season Performance, ORNL/Sub/81-7685/1\&92 (February 1984) ${ }^{\dagger}$

179 M. A. Kuliasha and W. P. Poore, Assessment of the Load Management Potential of the Annual Cycle Energy System, ORNL/CON-140 (March 1984) ${ }^{\dagger}$ 
180 N. Domingo, W. L. Jackson and F. C. Chen, A Theoretical Analysis of a Kinematic Stirling-Cycle Heat Pump for Space Conditioning Applications, ORNL/CON-149 (March 1984) ${ }^{\dagger}$

181 V. C. Mei, Laboratory Test of a Residential Low-Temperature Water Source Heat Pump, ORNL/CON-100 (May 1984) ${ }^{\dagger}$

182 M. G. Middleton and R. S. Sauber (Kelvinator Compressor Co.), Research and Development of Energy-Efficient High Back-Pressure Compressors, ORNL/Sub/78-7229/5 (September 1983, published May 1984) ${ }^{\dagger}$

183 S. Johnson et al. (Univ. of Tenn.), TECH House I Horizontal Coil Ground Coupled Heat Pump: 1983 Cooling Season Performance, ORNL/Sub/81-7685/2\&92 (May 1984) $)^{\dagger}$

184 W. F. Stoecker and C. I. McCarthy (Univ. of Illinois), The Simulation and Performance of a System Using an $R-12 / R-114$ Refrigerant Mixture, ORNL/Sub/81-7762/3\&01 (May 1984) ${ }^{\dagger}$

185 W: R. Huntley, Performance Test Results of a Lithium Bromide-Water Absorption Heat Pump that Uses Low-Temperature $\left[60^{\circ} \mathrm{C}\left(140^{\circ} \mathrm{F}\right)\right]$ Waste Heat, Final Report, ORNL/TM-9072 (June 1984) ${ }^{\dagger}$

186 Tectonics Research, Inc. and Honeywell, Inc., Development of a Braun Linear Engine-Driven, Heat-Actuated Heat Pump, Final Report, ORNL/Sub/80-61619/1 (July 1984) ${ }^{\dagger}$

187 N. C. J. Chen, F. P. Griffin and C. D. West, Linear Harmonic Analysis of Stirling Engine Thermodynamics, ORNL/CON-155 (August 1984) ${ }^{\dagger}$

188 V. C. Mei and S. K. Fischer, A Theoretical and Experimental Analysis of Vertical, Concentric-Tube Ground-Coupled Heat Exchange, ORNL/CON-153 (October 1984) ${ }^{\dagger}$

189 K. H. Zimmerman, "Laboratory Test, Design Model Validation, and Parametric Study of a Heat Pump Water Heater," pp VII-1-VII-6 in Proceedings of the Seventh Annual Heat Pump Technology Conference, Tulsa, Okla. (October 1984)*

190 E. A. Vineyard, "Predicted Energy Savings for a Residential Heat Pump Utilizing a Fluidized-Bed Heat Exchanger," pp. VIII-1-VIII-9 in Proceedings of the Seventh Annual Heat Pump Technology Conference, Tulsa, Okla. (October 1984)*

191 V. D. Baxter and J. C. Moyers, Air-Source Heat Pump: Field Measurement of Cycling, Frosting, and Defrosting Losses, 1981-83, ORNL/CON-150 (November 1984) $)^{\dagger}$

192 General Electric Co., Development and Demonstration of a Stirling/Rankine Heat Activated Heat Pump - Final Report - Phase IIIB, Engine Technology Development Testing, ORNL/Sub/82-17485/1 (November 1984) ${ }^{\dagger}$ 
193 D. H. Walker, M. Burnett, and I. P. Krepchin (Foster-Miller Assoc.), Research and Development of Highly Energy-Efficient Supermarket Refrigeration Systems, Volume 3-Evaluation of a Test System in a Supermarket, ORNL/Sub/80-61601/3 (December 1984) ${ }^{\dagger}$

194 N. Domingo, Comparative Analysis of a Stirling Heat Pump with Second-and ThirdOrder Computer Models, ORNL/CON-162 (June 1985) ${ }^{\dagger}$

195 K. P. Lee and W. M. Toscano (Aspen Systems, Inc.), Preliminary Design of a Linear Alternator Dynamometer for Free Piston Stirling Engines, ORNL/Sub/84-05907/1 (June 1985) ${ }^{\dagger}$

196 Honeywell, Inc, Hermetic Bellows Seal for Braun Linear Engine-Design, Test, and Demonstration, ORNL/Sub/80-61613/1 (June 1985) ${ }^{\dagger}$

197 J. C. Griess et al., Corrosion of Materials in Absorption Heating and Refrigeration Fluids, ORNL/TM-9646 (June 1985) ${ }^{\dagger}$

198 Mechanical Technology, Inc., Free-Piston Stirling Engine Diaphragm-Coupled HeatActuated Heat Pump Component Technology Program. Phase I/IA Final Report, ORNL/Sub/80-61618/1 (June 1985) † $^{\dagger}$

199 F. J. Zehr (Westminster College), The Performance and Economics of Superinsulated Houses, ORNL/CON-148 (June 1985) ${ }^{\dagger}$

200 H. Perez-Blanco and L. Pan, Comparative First- and Second-Law Analysis of an Absorption Cycle, ORNL/TM-9595 (July 1985) ${ }^{\dagger}$

201 Allied Corporation, Chemical Sector, Development of a Residential Gas Fired Absorption Heat Pump, Final Report-Physical and Thermodynamic Properties of R123a/ETFE System Development and Testing Economic Analysis, ORNL/Sub/79-24610/4 (August 1985) ${ }^{\dagger}$

202 Allied Corporation, Chemical Sector, Development of a Residential Gas Fired Absorption Heat Pump, Final Report-Component Development and Field Trial Program, ORNL/Sub/79-24610/3 (August 1985) ${ }^{\dagger}$

203 S. Johnson et al. (Univ. of Tenn.), TECH House I Horizontal Coil Ground Coupled Heat Pump: 1983-84 Annual Performance, ORNL/Sub/81-7685/3\&92 (August 1985) ${ }^{\dagger}$

204 K. H. Zimmerman, ed., Proceedings of the DOE/ORNL Heat Pump Conference: Research and Development of Heat Pumps for Space Conditioning Applications, CONF-841231 (August 1985) ${ }^{\dagger}$

205 K. H. Zimmerman, Heat Pump Water Heater Laboratory Test and Design Model Validation, ORNL/CON-173 (March 1986)*

206 R. S. Dougall et al. (Univ. of Pittsburgh), Monitoring of Residential GroundwaterSource Heat Pumps in the Northeast. Final Report, ORNL/Sub/80-7985/1 (March 1986)* 
207 K. H. Zimmerman, ed., Proceedings of the National Workshop. Field Data Acquisition for Building and Equipment Energy-Use Monitoring, Dallas, Texas, October 16-18, 1985, CONF-8510218 (March 1986)*

208 J. C. Burke, K. F. Fitzgerald and L. Frantzis (A. D. Little, Inc.), Summary and Evaluation of Field Performance Data on Unitary Heat Pumps, ORNL/Sub/85-00219/1 (April 1986)*

209 Arthur D. Little, Inc., Status of Free Piston Stirling Engine Driven Heat Pumps: Development, Issues, and Options. Final Report, ORNL/Sub/84-00205/1 (April 1986)

210 G. Grossman and E. Michelson (Technion-Israel Inst. of Tech.), Absorption Heat Pump Simulation and Studies, A Modular Computer Simulation of Absorption Systems, Final Report, ORNL/Sub/83-43337/2 (April 1986)*

211 R. A. Macriss and T. S. Zawacki (Inst. of Gas Technology), Absorption Fluids Data Survey: Final Report on USA Data, ORNL/Sub/84-47989/1 (May 1986)*

212 D. W. Yarbrough et al., Development of Advanced Thermal Insulation for Appliances, Progress Report for the Period July 1984 Through June 1985, ORNL/CON-199 (May 1986)*

213 D. Boggs and W. F. Stoecker (Univ. of Illinois), Performance and Simulation of Once-Through and Separating Cycles Using Nonazeotropic Refrigerant Mixtures, ORNL/Sub/81-7762/5\&01 (June 1986)*

214 H. Perez-Blanco and M. R. Patterson, Conceptual Design and Optimization of a Versatile Absorption Heat Transformer, ORNL/TM-9841 (June 1986)*

215 N. C. J. Chen and F. P. Griffin, Linear Harmonic Analysis of Free-Piston Stirling Engines, ORNL/CON-172 (June 1986)*

216 A. M. Perry, Environmental Effects of Chlorofluorocarbons: Will Restrictions Be Needed? ORNL/TM-9817 (October 1986)*

217 W. Mulroy and D. Didion (National Bureau of Standards), The Performance of a Conventional Residential Sized Heat Pump Operating With a Nonazeotropic Binary Refrigerant Mixture, NBSIR 86-3422 (October 1986) ${ }^{\dagger}$

218 T. J. Fagan et al. (Westinghouse Electric Corp.), Engineering Field Evaluation of the Westinghouse/DOE Dual-Stroke Advanced Electric Heat Pump, ORNL/Sub/7924712/4 (November 1986)*

219 V. C. Mei, Horizontal Ground-Coil Heat Exchanger Theoretical and Experimental Analysis, ORNL/CON-193 (December 1986)*

220 P. A. Domanski and D. A. Didion (National Bureau of Standards), Impact of Refrigerant Property Uncertainties on Prediction of Vapor Compression .Cycle Performance, NBSIR 86-3373 (February 1987) ${ }^{\dagger}$ 
221 W. S. Johnson et al. (Univ. of Tenn.), Final Report: 1984-85 Annual Performance Testing and Analysis of Two Horizontal Coil Ground-Coupled Heat Pump Systems, ORNL/Sub/81-7685/4\&92 (April 1987)*

222 R. A. Macriss, J. M. Gutraj and T. S. Zawacki, Absorption Fluids Data Survey: Final Report on Foreign Data, ORNL/Sub/84-47989/2 (April 1987)*

223 K. H. Zimmerman, U.S. Heat Pump Research and Development Projects 1976-1986, ORNL/CON-224 (April 1987)*

224 K. H. Zimmerman and R. H. Powell, Jr., eds., Heat Pumps. Prospects in Heat Pump Technology \& Marketing (Chelsea, Michigan: Lewis Publishers, Inc., 1987) ${ }^{\dagger}$

225 C. K. Rice, "The Effect of Void Fraction Correlation and Heat Flux Assumption on Refrigerant Charge Inventory Predictions," ASHRAE Trans 93(1), pp. 341-67 (Atlanta: American Society of Heating, Refrigerating, and Air-Conditioning Engineers, 1987)*

226 R. H. Turner (Univ. Nevada-Reno) and F. C. Chen, "Research Requirements in the Evaporative Cooling Field," ASHRAE Trans 93(1), pp. 185-96 (Atlanta: American Society of Heating, Refrigerating, and Air-Conditioning Engineers, 1987)*

227 D. T. Beecher and T. J. Fagan (Westinghouse), "Effects of Fin Pattern on the Air-Side Heat Transfer Coefficient in Plate Finned-Tube Heat Exchangers," ASHRAE Trans 93(2) (Atlanta: American Society of Heating, Refrigerating, and Air-Conditioning Engineers, 1987)*

228 W. A. Miller, "Steady-State Refrigerant Flow and Airflow Control Experiments for a Continuously Variable Speed Air-to-Air Heat Pump," ASHRAE Trans 93(2) (Atlanta: American Society of Heating, Refrigerating, and Air-Conditioning Engineers, 1987)*

229 V. C. Mei, "Effect of Backfilling Material on Ground Coil Performance," ASHRAE Trans 93(2) (Atlanta: American Society of Heating, Refrigerating, and AirConditioning Engineers, 1987)*

230 R. A. Ackermann (Mechanical Technology, Inc.), J. M. Clinch (Gas Research Inst.) and G. T. Privon, "Further Developments in the Design of a Free-Piston Stirling Engine Heat Pump for Residential Applications," ASHRAE Trans 93(2) (Atlanta: American Society of Heating, Refrigerating, and Air-Conditioning Engineers, 1987)* 


\section{BUILDING THERMAL ENVELOPE SYSTEMS AND MATERIALS}

231 John Weidt Assoc., Inc., Minnesota Retrofit Insulation In Situ Test Program Extension and Review, ORNL/Sub-79/13660/1 (February 1980) ${ }^{\dagger}$

232 R. P. Tye et al. (Dynatech Scientific, Inc.), An Experimental Study of Thermal Resistance Values (R-Values) of Low-density Mineral-fiber Building Insulation Batts Commercially Available in 1977, ORNL/TM-7266 (April 1980)

233 Oregon Department of Energy, A Field Study of Moisture Damage in Walls Insulated Without a Vapor Barrier, ORNL/Sub-78/97726/1 (May 1980) ${ }^{\dagger}$

234 K. W. Childs, An Appraisal of the $M$ Factor and the Role of Building Thermal Mass in Energy Conservation, ORNL/CON-46 (July 1980) ${ }^{\dagger}$

235 Princeton University, Smoldering Combustion Hazards of Thermal Insulation Materials, ORNL/Sub-7686/1 (July 1980) ${ }^{\dagger}$

236 R. Weil, A. Graviano and K. Sheppard (Stevens Inst. Tech.), Corrosion Testing of Urea-Formaldehyde Foam Insulating Material, ORNL/Sub-7556/2 (September 1980) ${ }^{\dagger}$

237 D. W. Yarbrough and I. Toor (Tenn. Tech. Univ.), Operating Temperatures for a Convectively Cooled Recessed Incandescent Light Fixture, ORNL/Sub-7715/1 (December 1980) ${ }^{\dagger}$

238 H. A. Fine et al., Analysis of Heat Transfer in Building Thermal Insulation, ORNL/TM-7481 (December 1980) ${ }^{\dagger}$

239 T. Isaksen, E. Paulsen and H. Juul (Norwegian Roofing Research Group), Roofing Felt on Polystyrene, ORNL/Tr-4679 (December 1980) ${ }^{\dagger}$

240 K. W. Childs, An Experimental Plan for Investigating Building-Earth Heat Transfer at the Joint Institute for Heavy Ion Research Building, ORNL/CON-61 (December $1980)^{\dagger}$

241 W. C. Schutte et al. (Univ. Iowa), Problems Associated with the Use of UreaFormaldehyde Foam for Residential Insulation Part II: The Effects of Temperature and Humidity on Free Formaldehyde, Extractable Formaldehyde, Formaldehyde Emission, and Physical Characteristics of the Foam, ORNL/Sub-7559/2 (February $1981)^{\dagger}$

242 W. C. Schutte et al. (Univ. Iowa), Problems Associated with the Use of UreaFormaldehyde Foam for Residential Insulation Part III: Residential Studies in Colorado and Wisconsin, ORNL/Sub-7559/3 (February 1981) ${ }^{\dagger}$

243 K. P. Long and W. C. Schutte (Univ. Iowa), Problems Associated with the Use of Urea-Formaldehyde Foam for Residential Insulation Part IV: The Relevance of Materials Standards to Problems Associated with the Use of Urea-Formaldehyde Foam Insulation, ORNL/Sub-7559/4 (February 1981) ${ }^{\dagger}$ 
244 J. N. Robinson and C. L. Nichols, Roofing Research-A Bibliography, ORNL/TM7629 (April 1981) $^{\dagger}$

245 D. W. Yarbrough and J. H. Wright (Tenn. Tech. Univ.), Reduction in the Thermal Resistance (R-Value) of Loose-Fill Insulation and Fiberglass Batts Due to Compression, ORNL/Sub-7715/2 (April 1981) ${ }^{\dagger}$

246 C. S. Dudney and P. J. Walsh, Report of Ad Hoc Task Force on Indoor Air Quality, ORNL/TM-7679 (April 1981) ${ }^{\dagger}$

247 D. W. Yarbrough and J. H. Wright (Tenn. Tech. Univ.), The Effect of Vibrations on the Density of Loose-Fill Insulations, ORNL/Sub-7715/3 (May 1981) ${ }^{\dagger}$

248 D. W. Yarbrough and I. A. Toor (Tenn. Tech. Univ.), Operating Temperatures of Recessed Fluorescent Fixtures with Thermal Insulation, ORNL/Sub-7715/4 (May 1981) $)^{\dagger}$

249 R. P. Tye and A. O. Desjarlais (Dynatech Scientific, Inc.), Performance Characteristics of Foamed-In-Place Urea-Formaldehyde Insulation, ORNL/Sub-78/86993/1 (June 1981)

250 J. N. Robinson, The Assessment of Roofing Research: An Interim Report, ORNL/TM-7640 (July 1981)

251 G. E. Courville, Assessment of Building Diagnostics, ORNL/Sub/80-61602/1 (July $1981)^{\dagger}$

252 F. Snow et al. (DCS Corp.), Status of Thermal Imaging Technology as Applied to Conservation-Update I, DOE/CS/20413-01 (July 1981) ${ }^{\dagger}$

253 Kenneth Labs, Regional Analysis of Ground and Above-Ground Climate, ORNL/Sub81/40451/1 (December 1981) ${ }^{\dagger}$

254 R. L. Wendt, G. E. Giles and J. E. Park, Large Climate-Moderating Envelopes for Enclosed Structures: A Preliminary Evaluation of Energy Conservation Potential, ORNL/TM-8018 (December 1981) ${ }^{\dagger}$

255 D. W. Yarbrough, D. L. McElroy and W. W. Harris, Properties and Testing of Loose-Fill Cellulosic Insulation, ORNL/TM-6433 (February 1982) ${ }^{\dagger}$

256 TLH Associates, Inc., Financing Earth-Sheltered Housing-A. Report on a Project to Facilitate the Loan Process, ORNL/Sub/80-70513/1 (February 1982) ${ }^{\dagger}$

257 P. R. Achenbach, The National Program Plan for the Thermal Performance of Building Envelope Systems and Materials, ORNL/Sub-7973/1 (March 1982) ${ }^{\dagger}$

258 R. L. Wendt, Earth-Sheltered Housing, An Evaluation of Energy Conservation Potential, ORNL/CON-86 (April 1982) ${ }^{\dagger}$ 
Building Thermal Envelope

Systems and Materials

259 R. L. Wendt et al., Use of Vegetation to Ameliorate Building Microclimates: An Assessment of Energy Conservation Potential, ORNL/CON-87 (April 1982) ${ }^{\dagger}$

260 C. S. Dudney, N. F. Hinkle and J. M. Becker, On the Occurrence of Fungi in LooseFill Attic Insulation in Typical Single-Family Dwellings, ORNL/CON-93 (May 1982) ${ }^{\dagger}$

261 J. Schott and E. Wilkinson (Calspan Corp.), Aerial Measurements of Heat Loss: Phase II, ORNL/Sub-9001/1 (July 1982) ${ }^{\dagger}$

262 Robert W. Anderson \& Assoc., Inc., Proceedings of the Cellulose I Conference, June 27-28, 1978, St. Louis, Missouri, ORNL/Sub/81-40447/1 (August 1982) ${ }^{\dagger}$

263 A. L. Berlad et al. (SUNY-Stony Brook), Energy Transport in Porous Insulation Systems II. Performance of Vertical Enclosures, ORNL/Sub-7551/2 (August 1982) ${ }^{\dagger}$

264 J. Schott and E. Wilkinson (Calspan Corp.), Community Demonstration of Aerial Thermography Techniques, ORNL/Sub-9001/2 (August 1982) ${ }^{\dagger}$

265 M. G. Van Geem, A. E. Fiorato and J. T. Julien (Construction Technology Labs), Heat Transfer Characteristics of a Structural Normal Weight Concrete Wall, ORNL/Sub-42539/1 (February 1983) ${ }^{\dagger}$

266 D. R. Johnson and R. A. LaCosse (National Roofing Contractors Assoc.), Thermal Roof Systems Performance Study, ORNL/Sub/86-95006C (March 1983) ${ }^{\dagger}$

267 J. E. Christian, Thermal Envelope Field Measurements in an Energy-Efficient Office and Dormitory, ORNL/TM-8571 (April 1983) ${ }^{\dagger}$

268 A. C. Jordan, Buildings Energy Research: A Bibliography-Publications of the Buildings System Division, ORNL/CON-122 (April 1983) ${ }^{\dagger}$

269 K.-H. Bode (Physikkalisch-Technische Bundesanstalt), Thermal Conductivity Measurement with the Plate Apparatus: Influence of the Guard Ring Width on the Accuracy of Measurements, ORNL/Tr-4932 (May 1983) ${ }^{\dagger}$

270 M. G. Van Geem (Construction Technology Labs), Heat Transfer Characteristics of a Structural Lightweight Concrete Wall, ORNL/Sub-42539/2 (June 1983) ${ }^{\dagger}$

271 M. G. Van Geem (Construction Technology Labs), Heat Transfer Characteristics of Low Density Concrete Wall, ORNL/Sub-42539/3 (August 1983) ${ }^{\dagger}$

272 G. E. Courville and E. L. Bales, eds., Proceedings of the Building Thermal Mass Seminar 1982, CONF-8206130 (August 1983) ${ }^{\dagger}$

273 H. B. Shapira et al., Cost and Energy Comparison Study of Above- and Below-ground Dwellings, ORNL/CON-91 (August 1983) ${ }^{\dagger}$

274 K. W. Childs, G. E. Courville and E. L. Bales, Thermal Mass Assessment-An Explanation of the Mechanisms by which Building Mass Influences Heating and Cooling Energy Requirements, ORNL/CON-97 (September 1983) ${ }^{\dagger}$ 
Building Thermal Envelope Systems and Materials

275 D. W. Yarbrough, Assessment of Reflective Insulations for Residential and Commercial Applications, ORNL/TM-8891 (October 1983) ${ }^{\dagger}$

276 C. V. Chester et al., Hazard Mitigation Potential of Earth-Sheltered Residences, ORNL-5957 (November 1983) ${ }^{\dagger}$

277 C. D. Scarpellino et al. (Univ. of Iowa), Problems Associated with the Use of UreaFormaldehyde Foams for Residential Insulation-Part V: Effects of UFFI Additives on Formaldehyde Emission and Physical Characteristics of the Foam, ORNL/Sub/78-7559/5 (December 1983) ${ }^{\dagger}$

278 T. Chang and H. W. Busching (Clemson Univ.), Energy Savings Potential of Roofing Research, ORNL/Sub/82-22293/1 (December 1983) ${ }^{\dagger}$

279 D. Whiting (Portland Cement Assoc.), Assessment of Potential Techniques for InSitu, Real Time Moisture Measurements in Building Envelope Systems-A Literature Survey, ORNL/Sub/83-40122/1 (February 1984) ${ }^{\dagger}$

280 W. A. Kleinfelder (Underwriters Laboratories), Investigation of the Fire Performance of Building Insulation in Full-Scale and Laboratory Fire Tests, ORNL/Sub/79-7863/1 (April 1984) ${ }^{\dagger}$

281 J. Gustinis and D. K. Robertson (Univ. of New Mexico), Southwest Thermal Mass Study: The Effect of Envelope Thermal Mass on the Heating Energy Use of Eight Test Buildings in a High Desert Climate, Research Phase I, ORNL/Sub-7948/1 (April 1984)

282 K. Sheppard and R. Weil (Stevens Inst. of Tech.), Corrosiveness Testing of Thermal Insulating Materials, ORNL/Sub/78-7556/3 (May 1984) ${ }^{\dagger}$

283 G. E. Courville and J. O. Kolb, Economic Analyses of Insulation Materials Used in Low-Slope, Built-Up Roof Systems, ORNL/TM-9004 (June 1984) ${ }^{\dagger}$

284 J. E. Christian, Cooling Season Performance of an Earth-Sheltered Office/Dormitory Building in Oak Ridge, Tennessee, ORNL/CON-151 (July 1984) ${ }^{\dagger}$

285 D. L. McElroy and D. W. Yarbrough, Development of Advanced Insulation for Appliances, ORNL/CON-159 (July 1984)

286 D. K. Robertson (Univ. of New Mexico), Observation and Prediction of the Heating Season Thermal Mass Effect for Eight Test Buildings With and Without Windows, ORNL/Sub/80-7948/2 (September 1984) ${ }^{\dagger}$

287 G. Gillette and S. Treado (American Inst. of Architects), Correlations of Solar Irradiance and Daylight Illuminance for Building Energy Analysis, ORNL/Sub/81$22201 / 2$ (October 1984) ${ }^{\dagger}$

288 M. G. Van Geem (Portland Cement Co.), Calibration Hot Box Test Results Data Manual-Vol. 1, ORNL/Sub/79-42539/4 (November 1984) ${ }^{\dagger}$ 
289 R. Sterling et al. (Univ. Minn.), Assessment of the Energy Saving Potential of Building Foundations Research, ORNL/Sub/84-00240/1 (January 1985) ${ }^{\dagger}$

290 G. Gillette and S. Treado (American Inst. of Architects), The Issue of Sky Conditions, ORNL/Sub/81-22201/3 (April 1985) ${ }^{\dagger}$

291 H. W. Busching and J. P Porcher, Jr. (Clemson Univ.), Roofing Industry Perspective and Research Capability, ORNL/Sub/82-22293/2 (March 1985) ${ }^{\dagger}$

292 A. C. Jordan and J. M. Riordan, Buildings Energy Research: A Bibliography, ORNL/CON-122/R1 (April 1985) ${ }^{\dagger}$

293 M. A. Brown, An Evaluation of the Institute on Energy and Engineering Education, ORNL/TM-9482 (April 1985)

294 G. E. Courville and D, J. Walukas, Insulation System Basics for Built-Up Roofs, ORNL-6171 (June 1985) ${ }^{\dagger}$

295 D. J. Walukas and G. E. Courville, Decision Guide for Roof Insulation R-Value, ORNL-6172 (June 1985) ${ }^{\dagger}$

296 J. E. Janssen and R. W. Rasmussen (Honeywell), Research and Development of a Diagnostic Procedure to Measure Changes in Thermal.Integrity of Building Envelopes, ORNL/Sub/84-47959/1 (June 1985) ${ }^{\dagger}$

297 J. P. Silvers et al. (Dynatech Scientific, Inc.), A Survey of Building Envelope Thermal Anomalies and Assessment of Thermal Break Materials for Anomaly Correction, Volume I-Survey and Assessment, ORNL/Sub/83-70376/1 (July 1985) ${ }^{\dagger}$

298 J. P. Silvers and R. P. Tye (Dynatech Scientific, Inc.), A Survey of Building Envelope Thermal Anomalies and Assessment of Thermal Break Materials for Anomaly Correction, Volume II-Proceedings of the Department of Energy Workshop, ORNL/Sub/83-70376/2 (July 1985) ${ }^{\dagger}$

299 M. A. Brown et al., A Strategy for Accelerating the Use of Energy-Conserving Building Technologies, ORNL/TM-9630 (July 1985) ${ }^{\dagger}$

300 M. G. Van Geem and S. C. Larson (Portland Cement Assoc.), Calibrated Hot Box Test Results Data Manual-Vol. II, ORNL/Sub/79-42539/5 (August 1985) ${ }^{\dagger}$

301 T. W. Tong (Univ. of Kentucky), Analysis of Transient Behavior and Radiation Measurements of Commercial Thermal Insulation, ORNL/Sub/83-43366/1 (August 1985) ${ }^{\dagger}$

302 K. W. Childs, Analysis of Calibrated Hot Box Data for Three Concrete Walls, K/CSD/TM-56 (September 1985) ${ }^{\dagger}$

303 J. E. Christian, Detailed Thermal Performance Measurements and Cost Effectiveness of Earth-Sheltered Construction: A Case Study, ORNL/CON-186 (September 1985) ${ }^{\dagger}$ 
304 P. G. Klemens (Univ. of Conn.), Radiative Heat Transfer Under Transient Conditions, ORNL/Sub/84-89634/1 (October 1985) ${ }^{\dagger}$

305 G. E. Courville and H. W. Busching, Roof Research Center-A Preliminary Concept Paper, ORNL/CON-188 (November 1985) ${ }^{\dagger}$

306 K. W. Childs, The Use of Roof Temperature Modeling to Predict Necessary Conditions for Locating Wet Insulation with Infrared Thermography, K/CSD/TM-58 (November 1985) ${ }^{\dagger}$

307. E. D. Copenhaver, Use of Broker Organizations in Technology Transfer and Research Utilization for the Buildings Industry, ORNL/TM-9581 (December 1985) ${ }^{\dagger}$

308 R. S. Graves and D. W. Yarbrough, Thicknesses, Densities, and Calculated Thermal Resistances for Loose-Fill Rock Wool Installed in Two Attic Sections of a Manufactured House, ORNL/TM-9927 (February 1986)*

309 J. E. Park et al., Calculation of Heat Flux Through a Wall Containing a CavityComparison of Several Models, K/CSD/TM-59 (February 1986)*

310 L. R. Glicksman, A. G. Ostrogorsky and S. Chiappetta (Mass. Inst. of Tech.), Effective Conductivity of Aging Polyurethane Foam, ORNL/Sub/84-9009/1 (March 1986)*

311 R. Troyer (Manville Service Corp.), High Temperature Calorimeter Performance Variable Study, ORNL/Sub/84-19712/1 (April 1986)*

312 E. L. Bales (N.J. Inst. of Tech.), Building Materials Research Agenda, ORNL/Sub/84-9733/1 (April 1986)*

313 T. W. Tong (Univ. of Kentucky), Transient Heat Transfer Analysis and Radiative Properties Measurements of Porous Thermal Insulation, ORNL/Sub/84-43366/2 (May 1986)*

314 S. C. Larson and M. G. Van Geem (Construction Tech. Labs.), Heat Transfer Characteristics of Walls With Similar Thermal Resistance Values, ORNL/Sub/79-42539/6 (June 1986)*

315 S. C. Larson and M. G. Van Geem (Construction Tech. Labs.), Surface Temperature Measurement Techniques for a Calibrated Hot Box Test Specimen, ORNL/Sub/79-42539/7 (June 1986)*

316 P. C. Martin and J. D. Verschoor (Manville Service Corp.), Investigation of Dynamic Latent Heat Storage Effects of Building Construction and Furnishing Materials, ORNL/Sub/86-22016/1 (August 1986)*

317 A. G. Ostrogorsky and L. R. Glicksman (Mass. Inst. of Tech.), Aging of Polyurethane Foams, The Influence of Gas Diffusion on Thermal Conductivity, ORNL/Sub/84$9009 / 2$ (August 1986)* 
318 D. W. Yarbrough et al., The Thermal Resistance of Perlite-Based Evacuated Insulations for Refrigerators, ORNL/CON-215 (September 1986)*

319 B. D. Nelson et al. (Minn. Dept. of Energy and Econ. Development), Energy Efficient House Research Project, ORNL/Sub/83-47980/1 (September 1986)*

320 R. Sterling et al. (Univ. Minn.), Assessment of the Energy Savings Potential of Building Foundations Research Summary Report, ORNL/Sub/85-27497/1 (November 1986)*

321 J. E. Christian, Building Foundations Research Agenda, ORNL/CON-222 (December 1986)*

322 D. Prowler, E. Johnson-Mohler and M. Aseltine (Univ. Penn.), Inventory of Energy Research in Schools of Architecture 1972-1985, ORNL/Sub/84-89680/1 (January 1987)*

323 W. L. Carroll, R. Sullivan and A. Mertol (Lawrence Berkeley Laboratory), Thermal Mass: Blast Residential Parametric Simulations, ORNL/Sub/83-70373/1 (LBL-19681) (January 1987)*

324 W. L. Carroll, A. Mertol and R. Sullivan (Lawrence Berkeley Laboratory), Thermal Mass: A Comparison of Measurements and Blast Predictions for Six Test Cells in Two Climates, ORNL/Sub/83-70373/2 (LBL-18020) (January 1987)*

325 S. C. Larson and M. G. Van Geem (Construction Technology Laboratories), Structural Thermal Break Systems for Buildings-Feasibility Study, ORNL/Sub/84-21006/1 (March 1987)*

326 G. E. Courville, The Roof Research Center, A National User Facility for Thermal Performance and Durability of Roofing Systems. Interim Users Manual, Oak Ridge National Laboratory (April 1987)*

327 K. R. Amirkhanian and H. W. Busching (Clemson Univ.), Ultraviolet Radiation Testing of Roofing Systems, ORNL/Sub/85-27453/1 (July 1987)*

328 D. W. Yarbrough, R. S. Graves and D. L. McElroy, Thickness and Density Measurements for Attic Loose-Fill Thermal Insulations in Eight Cities, ORNL/TM-10414 (August 1987)*

329 M. G. Van Geem and S. T. Shirley (Construction Technology Laboratories), Heat Transfer Characteristics of Insulated Concrete Sandwich Panel Walls, ORNL/Sub/79-42539/8 (September 1987)*

330 H. A. McLain et al., Simulation of the SWTMS Test Cells Using the DOE-2.IA Model, ORNL/CON-221 (September 1987)*

331 N. Pearman (Honeywell, Inc.), A Combustion System Seasonal Efficiency Meter-A Preliminary Assessment of a Laboratory Model, ORNL/Sub/85-53142/1 (September 1987)* 

Systems and Materials

332 R. P. Tye (Dynatech Scientific, Inc.), Assessment of Foam-in-Place Urethane Foam Insulations Used in Buildings, ORNL/Sub/86-56525/1 (October 1987)*

333 J. Christian, Impact of CFC Restrictions on U.S. Building Foundation Thermal Performance, ORNL/CON-245 (December 1987)*

334 B. S. Melton and P. Mulroney (VVKR, Inc.), Building Envelope Thermal Anomaly Analysis, ORNL/Sub/85-00294/1 (December 1987)* 


\section{COMMUNITY SYSTEMS AND COGENERATION}

335 R. E. Sundberg (Minn. Energy Agency) et al., District Heating/Cogeneration Application Studies for the Minneapolis-St. Paul Area: Institutional Issues of New District Heating/Cogeneration System-Ownership Options, Barriers, and Implementation Study, ORNL/TM-6830/P5 (January 1980)

336 W. T. Davis (Univ. Tenn.) and J. O. Kolb, Environmental Assessment of Air Quality, Noise and Cooling Tower Drift from the Jersey City Total Energy Demonstration, ORNL/HUD/MIUS-52 (June 1980) ${ }^{\dagger}$

337 R. E. Gant, Application of Modular Integrated Utility Systems Concepts as a Strategy for Urban Rehabilitation and Redevelopment, ORNL/HUD/MIUS-53 (September 1980) ${ }^{\dagger}$

338 G. A. Englesson (United Engrs. and Constructors, Inc.) et al., District Heating/Cogeneration Application Studies for the Minneapolis-St. Paul Area: Modifications of the Existing Units at the High Bridge Power Plant to Cogeneration for Hot Water District Heating, ORNL/TM-6830/P9 (October 1980) ${ }^{\dagger}$

339 G. F. Pavlenco and G. A. Englesson (United Engrs. and Constructors, Inc.), District Heating/Cogeneration Application Studies for the Minneapolis-St. Paul Area: Allocation Methods for the Separation of Electrical and Thermal Cogeneration Costs, ORNL/TM-6830/P12 (October 1980) ${ }^{\dagger}$

340 M. A. Karnitz et al., District Heating/Cogeneration Application Studies for the Minneapolis-St. Paul Area: Impact of a District Heating/Cogeneration System on Annual Average $\mathrm{SO}_{2}$-Air Quality in the Twin Cities, ORNL/TM-6830/P11 (March $1981)^{\dagger}$

341 Department of Energy, Industrial Cogeneration Optimization Program: A Summary of Two Studies, DOE/TIC-11604 (August 1981) ${ }^{\dagger}$

342 Department of Energy, Handbook of Industrial Cogeneration, DOE/TIC-11605 (October 1981) ${ }^{\dagger}$

343 R. E. Gant et al., Potential Opportunities for Revitalization of the Rochester, New York, Steam District Heating System, ORNL/TM-7757 (September 1981) ${ }^{\dagger}$

344 M. A. Broders, Potential for District Heating: An Historical Overview, ORNL/TM7791 (October 1981) $^{\dagger}$

345 T. K. Stovall, R. J. Borkowski and M. A. Karnitz, Minneapolis District Heating Options, ORNL/TM-7780 (October 1981) ${ }^{\dagger}$ 
346 M. A. Karnitz et al., District Heating/Cogeneration Application Studies for the Minneapolis-St. Paul Area: St. Paul District Heating System Conceptual Design Study and Report, Appendix $C$ of Market Assessment and Economic Analysis of the St. Paul District Heating Demonstration Project, ORNL/TM-6830/P10, Vol. II (January 1982) ${ }^{\dagger}$

347 M. Eksel (Univ. Tenn.) et al., An Economic Evaluation of End-Use Conservation Measures Applied to Buildings Served by a Proposed District Heating System, ORNL/TM-8277 (May 1982) ${ }^{\dagger}$

348 G. A. Englesson et al. (United Engrs. and Constructors, Inc.), District Heating Cogeneration Application Studies for the Minnesota-St. Paul Area: Economic Comparison of New Coal-Fueled, Cogenerated Power Plants for District Heating and Electricity-Only and Heat-Only Power Plants, ORNL/TM-6830/P8 (May 1982) ${ }^{\dagger}$

349 M. A. Karnitz et al., Analysis of Akron, Ohio Steam District Heating Distribution Network, ORNL/TM-8173 (June 1982) ${ }^{\dagger}$

350 H. A. McLain, M. J. Brinker and D. W. Gatton, Potential Benefits of a Resource Recovery Facility Coupled with District Heating in Detroit, Michigan, ORNL/TM8463 (September 1982)

351 J. O. Kolb, Use of Municipal Solid Waste for District Heating in St. Paul, Minnesota, ORNL/TM-8076 (September 1982) ${ }^{\dagger}$

352 J. O. Kolb and K. Teichman, District Heating Cogeneration Application Studies for the Minnesota-St. Paul Area: Building Conversion Costs and Economics for the St. Paul Hot Water District Heating Market, ORNL/TM-6830/P7 (February 1983) ${ }^{\dagger}$

353 H. O. Nyman, J. O. Kolb, and M. Krautbauer, District Heating Cogeneration Applications Studies for the Minnesota-St. Paul Area: Market Assessment and Economic Analysis of the St. Paul District Heating System, ORNL/TM-6830/P10, Vol. 1 (February 1983) ${ }^{\dagger}$

354 M. A. Karnitz and J. O. Kolb, District Heating Cogeneration Applications Studies for the Minnesota-St. Paul Area: Summary of Twin Cities Case Study and the St. Paul Project, ORNL/TM-6830/P1 (February 1983) ${ }^{\dagger}$

355 L. N. McCold and M. A. Karnitz, Preliminary Assessment of Decentralized Small Cogeneration for Navy Shore Bases, ORNL/CON-141 (March 1984) ${ }^{\dagger}$

356 J. O. Kolb, H. F. Bauman and P. D. Jones, Technical Feasibility and Economics of Retrofitting an Existing Nuclear Power Plant to Cogeneration for Hot Water District Heating, ORNL/TM-8778 (April 1984) ${ }^{\dagger}$

357 H. A. McLain et al., Environmental Aspects of District Heating/Cogeneration in the Twin Cities, ORNL/TM-9013 (April 1984) ${ }^{\dagger}$

358 J. V. Beck (Mich. St. Univ.) and M. A. Karnitz, Parameter Estimation Study of Heat Losses from Underground Steam Pipelines, ORNL/TM-9928 (June 1986)* 
359 M. H. Barnes (Scantec, Inc.) et al., Characterization and Potential of Nonmetallic Piping Systems for District Heating, ORNL/TM-10234 (July 1987)* 


\section{RESIDENTIAL CONSERVATION SERVICE}

360 Hittman Associates and United Engineers and Constructors, Inc., Residential Conservation Service Planning and Implementation Guide, ORNL/Sub/79-24718/1 and ORNL/Sub/79-37902 (January 1980)

361 Hittman Associates, Residential Conservation Service Planning and Implementation Guide for Home Heating Supplies, ORNL/Sub/79-24718/2 (April 1980) ${ }^{\dagger}$

362 T. K. Stovall and C. K. Bayne, RCS Program Evaluation Plan Options, ORNL/TM7380 (October 1980) ${ }^{\dagger}$

363 L. Berry et al., Review of Utility Home Energy Audit Programs, ORNL/CON-58 $(\text { March 1981) })^{\dagger}$

364 D. R. Johnson and K. O. Olsen, "A Model Energy Audit Procedure for the RCS Program," pp. 542-66 in Proceedings of the Conference on Energy in the Man-Built Environment, Vail, Colorado, August 1981 (American Society of Civil Engineers, 1982)*

365 N. Domingo and E. G. Keshock, An Assessment of Seasonal Efficiency Models for Natural Gas-Fired Residential Furnaces, ORNL-5801 (September 1981) ${ }^{\dagger}$

366 L. M. Frogge, A. R. Ehrenshaft and L. E. Morris, Status of RCS Program in Selected States as of December 1981, ORNL/TM-8466 (September 1981) ${ }^{\dagger}$

367 T. F. Scanlan, C. K. Bayne and D. R. Johnson, Investigation of Attic Insulation Effectiveness Using Actual Energy Consumption Data, ORNL-5825 (September 1982)

368 F. Boercker, L. F. Menendez and L. M. Frogge, Basic Considerations for Monitoring and Evaluating the Residential Conservation Service, ORNL/CON-98 (November 1982)

369 L. E. Morris et al., Residential Conservation Service: Summary of the Second Annual Report Submitted to the Department of Energy by States and Non-Regulated Utilities, ORNL/CON-121. (February 1983) ${ }^{\dagger}$

370 M. Olszewski and E. C. Fontana, Heat Pump Desuperheaters for Supplying Domestic Hot Water-Estimation of Energy Savings and Economic Viability for Residential Application, ORNL/CON-114 (May 1983)

371 L. F. Menendez, The Residential Conservation Service in Connecticut: A Profile of CONN SAVE, ORNL/CON-126 (June 1983)

372 G. A. Kamp, K. Patel, and N. Carlisle, Study of Currently Available Commercial and Apartment Building Energy Conservation Audits, ORNL/CON-137 (September 1983) ${ }^{\dagger}$ 
373 M. Olszewski and H. A. McLain, Using a Whole-House Fan to Decrease Air-Conditioning: Energy Use-Estimate of Energy Savings and Economic Viability for Residential Applications, ORNL/CON-115 (September 1983) ${ }^{\dagger}$

374 M. A. Karnitz, T. K. Stovall and H. A. McLain, Residential Conservation Service Model Audit Manual, ORNL/CON-103 (October 1983) ${ }^{\dagger}$

375 T. K. Stovall, Verification of the DOE Model Audit, ORNL/CON-118 (November 1983) ${ }^{\dagger}$

376 T. K. Stovall, Interactive Savings Calculations for RCS Measures, Six Case Studies, ORNL/CON-117 (November 1983) ${ }^{\dagger}$

377 B. E. Tonn, Selection of States for Evaluation of the Residential Conservation Service, ORNL/CON-139 (November 1983) ${ }^{\dagger}$

378 F. D. Boercker, Technical Review of a Residential Conservation Service Measure: Insulation of Crawl Spaces, ORNL/CON-142 (January 1984) ${ }^{\dagger}$

379 L. N. McCold, Add-on Heat Pump for Residential Applications-Estimation of the Savings, ORNL/CON-116 (January 1984) ${ }^{\dagger}$

380 L. G. Berry and B. Tonn, Loan Impacts in Home Energy Audit Programs: A Minnesota Example, ORNL/CON-145 (February 1984) ${ }^{\dagger}$

381 H. A. McLain et al., Residential Conservation Service Model Audit Manual-Multifamily Audit Procedure, ORNL/CON-104 (April 1984) ${ }^{\dagger}$

382 T. A. Vineyard et al., Analysis of Post-Audit Energy Data at 41 Hospitals, ORNL/CON-165 (October 1984) ${ }^{\dagger}$

383 B. E. Tonn and L. G. Berry, Conservation Potentials, Participation, and Retrofit Choices in the Connecticut Residential Conservation Service (CONN SAVE) Project, ORNL/CON-161 (November 1984) ${ }^{\dagger}$

384 E. A. Hirst and R. Goeltz, Energy Savings One and Two Years after Participation in Minnesota Home Energy Audit and Retrofit Loan Programs, ORNL/CON-168 (January 1985)*

385 T. K. Stovall and M. A. Kuliasha, An Analysis of Lifestyle Effects on Residential Energy Use, ORNL/CON-170 (February 1985)*

386 R. J. Kedl and T. L. Bircher, Energy Conservation Case Studies for Model Commercial Buildings Covered by the CACS Program, ORNL/CON-133 (March 1985)*

387 R. J. Kedl and T. K. Stovall, Commercial and Apartment Conservation Service: Cost-Effectiveness of Single and Multiple CACS Conservation Actions in Small Commercial Buildings, ORNL/CON-176 (August 1985)*

388 J. L. Nicol and T. K. Stovall, Cost-Effectiveness of Single and Multiple CACS Retrofit Actions in Multifamily Apartment Buildings, ORNL/CON-191 (March 1986)* 
389 M. A. Brown et al., The Role of Auditor Sales Effectiveness in Residential Conservation Incentive Programs: A Case Study of Florida Power and Light, ORNL/CON-201 (August 1986)*

390 L. Berry, M. Hubbard and D. White, A Review of Financial Incentive, Low-Income, Elderly and Multifamily Residential Conservation Programs, ORNL/CON-206 (September 1986)* 


\section{RETROFIT RESEARCH}

391 L. G. Berry and T. A. Vineyard, Evaluation Plan for State Gas Heating System Retrofit Pilot Programs, ORNL/CON-171 (March 1985) ${ }^{\dagger}$

392 H. A. McLain et al., Benefits of Replacing Residential Central Air Conditioning Systems, ORNL/CON-113 (April 1985) ${ }^{\dagger}$

393 H. A. McLain, J. M. MacDonald and D. Goldenberg, "Appropriate Conservation Measures for Single-Family Buildings in Hot, Humid Climates," Proc. 2nd Annu. Symp. Improving Energy Efficiency in Hot and Humid Climates, Texas A\&M University, College Station, September 24-26, 1985, pp. 44-52 (1985) ${ }^{\dagger}$

394 J. M. MacDonald, L. Jung and J. A. Tevepaugh, "Estimation of Reference or Balance Point Temperature," ASHRAE Trans. 91(2B), pp. 1441-49 (1985) ${ }^{\dagger}$

395 W. R. Mixon and R. J. Kedl, "Predicted Energy Conservation in Existing Small Commercial Buildings," ASHRAE Trans. 91(2B), pp. 1510-14 (1985) ${ }^{\dagger}$

396 M. A. Karnitz, Single-Family Building Retrofit Research Multi-Year Plan FY 1986-FY 1991, ORNL/CON-207 (May 1986)*

397 W. P. Levins and M. A. Karnitz, Cooling-Energy Measurements of Unoccupied Single-Family Houses with Attics Containing Radiant Barriers, ORNL/CON-200 (July 1986)*

398 J. M. MacDonald et al., Commercial Retrofit Research Multi-Year Plan, FY 1986FY 1991, ORNL/CON-218 (October 1986)*

399 W. P. Levins and M. A. Karnitz, Heating-Energy Measurements of Unoccupied Single-Family Houses with Attics Containing Radiant Barriers, ORNL/CON-213 (January 1987)*

400 W. P. Levins and M. A. Karnitz, Cooling Energy Measurements of Single-Family Houses with Attics Containing Radiant Barriers in Combination with $R-11$ and R-30 Ceiling Insulation, ORNL/CON-226 (May 1987)*

401 M. P. Ternes, Single-Family Building Retrofit Performance Monitoring Protocol: Data Specification Guideline, ORNL/CON-196 (June 1987)*

402 T. R. Sharp and J. M. MacDonald, Estimating Balance Point Temperature for Residential Buildings, ORNL/CON-209 (August 1987)* 


\section{CERAMIC TECHNOLOGY FOR ADVANCED HEAT ENGINES}

403 V. J. Tennery, "Status, Needs, and Opportunities for Structural Ceramics in Advanced Heat Engines," pp. 433-43 in Defect Properties and Processing of High-Technology Nonmetallic Materials, Materials Research Society Symposia Proceedings 24 (November 1983)

404 A. J. Moorhead, T. N. Tiegs and R. J. Lauf, "Dispersed Metal-Toughened Ceramics and Ceramic Brazing," Proc. 21st Automotive Technology Development Contractors' Coordination Meeting, pp. 223-29 (Warrendale, Penn.: Society of Automotive Engineers, 1984) ${ }^{\dagger}$

405 P. F. Becher and G. C. Wei, "Toughening Behavior in SiC Whisker Reinforced Alumina," J. Am. Ceram. Soc. 67(12), pp. 259-60 (1984) ${ }^{\dagger}$

406 T. N. Tiegs and P. F. Becher, "SiC Whisker Reinforced Alumina," Bull. Am. Ceram. Soc. 63, p. $1013(1984)^{\dagger}$

407 A. C. Schaffhauser et al., Ceramic Technology for Advanced Heat Engines Program Plan, ORNL/TM-8896 (June 1984) ${ }^{\dagger}$

408 D. R. Johnson, Ceramic Technology for Advanced Heat Engines Project Semiannual Progress Report for Period March 1983-September 1983, ORNL/TM-9325 (October 1984)

409 D. R. Johnson et al., Ceramic Technology for Advanced Heat Engines Project Semiannual Progress Report for Period October 1983-March 1984, ORNL/TM-9466 (December 1984) ${ }^{\dagger}$

410 W. J. Lackey et al., Ceramic Coatings for Heat Engine Materials: Status and Future Needs, ORNL/TM-8959 (December 1984) ${ }^{\dagger}$

411 A. J. Moorhead, "Direct Brazing of Structural Ceramics for Uncooled Diesels," Proc. 22nd Automotive Technology Development Contractors' Coordination Meeting, pp. 531-39 (Warrendale, Penn.: Society of Automotive Engineers, 1985) ${ }^{\dagger}$

412 J. P. Hammond, S. A. David and J. J. Woodhouse, "Indirect Brazing of : Structural Ceramics for Uncooled Diesels," Proc. 22nd Automotive Technology Development Contractors' Coordination Meeting, pp. 523-29 (Warrendale, Penn.: Society of Automotive Engineers, 1985) ${ }^{\dagger}$

413 V. J. Tennery et al., "Characterization of the Fatigue and Slow Crack Growth Behavior of Partially Stabilized Zirconia Ceramics," Proc. 22nd Automotive Technology Development Contractors' Coordination Meeting, pp. 409-18 (Warrendale, Penn.: Society of Automotive Engineers, 1985) ${ }^{\dagger}$ 
414 T. N. Tiegs and P. F. Becher, "Particulate and Whisker Toughened Alumina Composites," Proc. 22nd Automotive Technology Development Contractors' Coordination Meeting, pp. 479-85 (Warrendale, Penn.: Society of Automotive Engineers, 1985) ${ }^{\dagger}$

415 D. R. Johnson et al., "Ceramic Technology for Advanced Heat Engines Project," Am. Ceram. Soc. Bul. 64(2), pp. 276-81 (1985) ${ }^{\dagger}$

416 G. C. Wei and P. F. Becher, "Development of SiC-Whisker-Reinforced Ceramics," Am. Ceram. Soc. Bul. 64(2), pp. 298-304 (1985) ${ }^{\dagger}$

417 D. P. H. Hasselman, R. Syed, and T. Y. Tien, "The Thermal Diffusivity and Conductivity of Transformation-Toughened Solid Solutions of Alumina and Chromia," J. Mat. Sci. 20(7), pp. 2549-56 (1985) ${ }^{\dagger}$

418 L. J. Schioler et al., "Mechanical Properties of Zirconia Toughened Alumina," Ceram. Eng. Sci. Proc. 6(7-8), pp. 822-25 (1985) ${ }^{\dagger}$

419 D. R. Johnson, Ceramic Technology for Advanced Heat Engines Project Semiannual Progress Report for Period April 1984-September 1984, ORNL/TM-9497 (February 1985) ${ }^{\dagger}$

420 D. R. Johnson, Ceramic Technology for Advanced Heat Engines Project Semiannual Progress Report for Period October 1984-March 1985, ORNL/TM-9673 (September 1985) ${ }^{\dagger}$

421 T. K. Brog, "Transformation Toughening in the Alumina-Chromia/Zirconia-Hafnia System," Diss. Abstr. Int. B 1986 47(3): p. 1218 (1986) ${ }^{\dagger}$

422 T. N. Tiegs and P. F. Becher, "Alumina-SiC Whisker Composites," Proc. 23rd Automotive Technology Development Contractors' Coordination Meeting, pp. 209-14 (Warrendale, Penn.: Society of Automotive Engineers, 1986) ${ }^{\dagger}$

423 M. L. Santella et al., "Zirconia-to-Cast Iron Brazing for Uncooled Diesel Engines," Proc. 23rd Automotive Technology Development Contractors' Coordination Meeting, pp. 235-41 (Warrendale, Penn.: Society of Automotive Engineers, 1986) ${ }^{\dagger}$

424 K. C. Liu and C. R. Brinkman, "Tensile Cyclic Fatigue of Structural Ceramics," Proc. 23rd Automotive Technology Development Contractors' Coordination Meeting, pp. 279-84 (Warrendale, Penn.: Society of Automotive Engineers, 1986) ${ }^{\dagger}$

425 T. N. Tiegs and P. F. Becher, "Whisker Reinforced Ceramic Composites," pp. 639-48 in Tailoring Multiphase and Ceramic Composites, 20, ed. R. E. Tressler et al. (New York: Plenum Press, 1986) ${ }^{\dagger}$

426 M. A. Janney, "Microstructural Development and Mechanical Properties of SiC and of SiC TiC Composites," Bull. Am. Ceram. Soc. 65, pp. 357-362 (1986) 
427. P. F. Becher et al., "Toughening Ceramics by Whisker Reinforcement," pp. 61-73 in Fracture Mechanics of Ceramics, 6, ed. R. C. Bradt al. (New York: Plenum Press, 1986) ${ }^{\dagger}$

428 P. F. Becher et al., "Whisker Reinforced Ceramics," pp. 61-73 in Fracture Mechanics of Ceramics, 7, ed. R. C. Bradt et al. (New York: Plenum Press, 1986) ${ }^{\dagger}$

429 G. M. Crosbie (Ford Motor Co.), "Preparation of Silicon Nitride Powders," Ceram. Eng. Sci. Proc. 7(9-10), pp. 1144-49 (1986) ${ }^{\dagger}$

430 Y. M. Pan et al., "Toughness Anisotropy of a Silicon Carbide/Silicon Carbide Laminar Composite," Mater. Sci. Res. 20 (Tailoring Multiphase Compos. Ceram.), pp. $631-38(1986)^{\dagger}$

431 M. Sakai and R. C. Bradt, "Graphical Methods for Determining the Nonlinear Fracture Parameters of Silica and Graphite Refractory Composites," Frac. Mech. Ceram. 7, pp. 127-42 (1986) ${ }^{\dagger}$

432 T. N. Tiegs and P. F. Becher, "Whisker Reinforced Ceramic Composites," Mater. Sci. Res, 20 (Tailoring Multiphase Compos. Ceram.), pp. 639-47 (1986) ${ }^{f}$

433 T. N. Tiegs and P. F. Becher, "Whisker-Reinforced Ceramic Composites," Ceramic Materials and Components for Engines (Second International Symposium), ed. W. Bunk and H. Hausner, pp. 193-200 (Bad Honnef: Deutsche Keramische Gesellschaft e.V, 1986) ${ }^{\dagger}$

434 S. M. Wiederhorn and E. R. Fuller, Jr., "Design Criteria for High Temperature Structural Applications," Ceramic Materials and Components for Engines (Second International Symposium), ed. W. Bunk and H. Hausner, pp. 911-929 (Bad Honnef: Deutsche Keramiche Gesellschaft e.V., 1986) ${ }^{\dagger}$

435 M. K. Ferber, "Characterization of the Mechanisms Responsible for Time-Dependent Strength Variations in Partially Stabilized Zirconia," Ceramic Materials and Components for Engines (Second International Symposium), ed. W. Bunk and $H$. Hausner, pp. 583-592 (Bad Honnef: Deutsche Keramische Gesellschaft e.V., 1986) ${ }^{\dagger}$

436 A. J. Moorhead and H. Keating, Joining of Ceramics for Advanced Heavy-Duty Diesels, ORNL-6262 (March 1986)*1

437 D. R. Johnson et al., Ceramic Technology for Advanced Heat Engines Project Semiannual Progress Report for Period April-September 1985, ORNL/TM-9947 (May 1986)*

438 K. F. Dufrane, "Sliding Performance of Ceramics for Advanced Heat Engines," Ceram. Eng. Sci. Proc. 7(7-8), pp. 1052-59 (July-August 1986) ${ }^{\dagger}$

${ }^{1}$ Also available from the National Aeronautics and Space Administration, report no. NASA CR-175019. 
439 D. R. Johnson et al., Ceramic Technology for Advanced Heat Engines Project Semiannual Progress Report for Period October 1985-March 1986, ORNL/TM-10079 (August 1986)*

440 T. J. Chuang, S. M. Wiederhorn and C. F. Chen, "Transient Behavior of Structural Ceramics under Flexural Creep," Proc. Third International Conference on Creep and Fracture of Engineering Materials and Structures, ed. B. Wiltshire and R. W. Evans (London: The Institute of Metals, 1987) ${ }^{\dagger}$

441 K. R. Carduner et al., "Determination of Silicon Nitride Crystallinity and Silicon Phase Composition of Silicon Nitride Powder by 29Si MASNMR," Analytical Chemistry 59(23), pp. 2794-97 (1987)

442 K. F. Dufrane and W. A. Glaeser, "Wear of Ceramics in Advanced Heat Engine Applications," 1987 Wear of Materials Conference, p. 285 (New York: American Society of Mechanical Engineers, 1987) ${ }^{\dagger}$

443 T. N. Tiegs and P. F. Becher, "Development of Alumina- and Mullite-SiC Whisker Composites: High Temperature Properties," Proc. 24th Automotive Technology Development Contractors' Coordination Meeting. Dearborn, Michigan, October 27-30, 1986 (Warrendale, Penn.: Society of Automotive Engineers, 1987)*

444 D. R. Johnson and R. B. Schulz, "Introduction and Status of the Ceramic Technology for Advanced Heat Engines," Proc. 24th Automotive Technology Development Contractors' Coordination Meeting, Dearborn, Michigan, October 27-30, 1986 (Warrendale, Penn.: Society of Automotive Engineers, 1987)*

445 T. N. Tiegs, P. F. Becher and M. A. Janney, "Development and Characterization of Whisker-Toughened Oxide Ceramics," Proc. 24th Automotive Technology Development Contractors' Coordination Meeting, Dearborn, Michigan, October 27-30, 1986 (Warrendale, Penn.: Society of Automotive Engineers, 1987)*

446 K. C. Liu and C. R. Brinkman, "Tensile Cyclic Fatigue of Alumina at Room and Elevated Temperatures," Proc. 24th Automotive Technology Development Contractors' Coordination Meeting, Dearborn, Michigan, October 27-30, 1986 (Warrendale, Penn.: Society of Automotive Engineers, 1987)*

447 M. G. Jenkins et al., "Crack Initiation and Arrest in an $\mathrm{SiC}$ Whisker $/ \mathrm{Al}_{2} \mathrm{O}_{3}$ Matrix Composite," J. Am. Ceram. Soc. 70(6), pp. 393-95 (1987) ${ }^{\dagger}$

448 M. G. Jenkins et al., "Fracture Toughness Testing of Ceramics Using a Laser Interferometric Strain Gage," Am. Ceram. Soc. Bull. 66(12), pp. 1734-38 (1987) ${ }^{\dagger}$

449 W. A. Glaeser, K. F. Dufrane, and A. R. Rosenfield, "Wear Mechanisms of Monolithic Ceramics Under Diesel Combustion Chamber," Proceedings of the Third Berkeley Conference on Elevated Temperature Corrosion-Erosion-Wear of Materials, pp. 333-51 (National Association of Corrosion Engineers, 1987) ${ }^{\dagger}$

450 T. N. Tiegs and P. F. Becher, "Sintered $\mathrm{Al}_{2} \mathrm{O}_{3}-\mathrm{SiC}$-Whisker Composites," Am. Ceram. Soc. Bul. 66(2), pp. 339-42 (1987) ${ }^{\dagger}$ 
451 P. F. Becher and M. K. Ferber, "Mechanical Behavior of MgO-Partially Stabilized $\mathrm{ZrO}_{2}$ Ceramics at Elevated Temperatures," J. Mater. Sci. 22, pp. 973-80 (1987) ${ }^{\dagger}$

452 P. F. Becher and T. N. Tiegs, "Temperature Dependence of Strengthening by Whisker Reinforcement: SiC Whisker Reinforced Alumina in Air," J. Mater. Sci. 22, pp. $973-80(1987)^{\dagger}$

453 S. T. Buljan, J. G. Baldoni, and $\mathrm{M}$. L. Huckabee, "Si $\mathrm{N}_{4}-\mathrm{SiC}$ Composites," Bull. Am. Ceram. Soc. 66(2), pp. 347-52 (1987)!

454 S. T. Buljan and $G$. Zilberstein, "Microstructure Development in $\mathrm{Si}_{3} \mathrm{~N}_{4}$-Based Composites," pp. 273-81 in Advanced Structural Ceramics, ed. P. F. Becher, M. V. Swain and S. Somiya, Materials Research Society Symposia Proceedings 78 $(1987)^{\dagger}$

455 J. J. Swab, "Evaluation of Commercially Available Transformation Toughened Zirconias," pp. 137-46 in Advanced Structural Ceramics, ed. P. F. Becher, M. V. Swain and S. Somiya, Materials Research Society Symposia Proceedings $78(1987)^{\dagger}$

456 R. J. Nixon et al., "Deformation Behavior of $\mathrm{SiC}$ Whisker-Reinforced $\mathrm{Si}_{3} \mathrm{~N}_{4}$, , pp. 295-301 in Advanced Structural Ceramics, ed. P. F. Becher, M. V. Swain and S. Somiya, Materials Research Society Symposia Proceedings 78 (1987) ${ }^{\dagger}$

457 R. K. Williams et al., "The Effects of $\mathrm{Cr}_{2} \mathrm{O}_{3}$ and $\mathrm{Fe}_{2} \mathrm{O}_{3}$ Additions on the Thermal Conductivity of $\mathrm{Al}_{2} \mathrm{O}_{3}, "$ J. Appl. Physics 61(10), pp. 4894-4901 (1987) ${ }^{\dagger}$

458 T. N.' Tiegs and P. F. Becher, "Thermal Shock Behavior of an Alumina-SiC Whisker Composite," J. Am. Ceram. Soc. 70, pp. C109-111 (1987) ${ }^{\dagger}$

459 D. R. Johnson, Ceramic Technology for Advanced Heat Engines Project Semiannual Progress Report for April through September 1986, ORNL/TM-10308 (March 1987)*

460 J. Schienle and J. Smyth (Garrett Turbine Engine Co.), High Temperature Coating Study to Reduce Contact Stress Damage of Ceramics. Final Report, ORNL/Sub/8447992/1 (March 1987)*

461 M. L. Lander, "Application of Laer Raman Macro- and Microprobes Using Cylindrical Optics to the Study of Zirconia Ceramic Materials," M.S. Thesis, Graduate Engineering and Research School of Engineering, University of Dayton, April $1987^{\dagger}$

462 W. D. Bond et al., Status of Experimental Studies on the Sol-Gel Synthesis of Ceramic Powders for High-Strength Ceramic Materials Applications, ORNL/TM-9835 (May 1987)*

463 D. R. Johnson, Ceramic Technology for Advanced Heat Engines Project Semiannual Progress Report for October 1986 through March 1987, ORNL/TM-10469 (August 1987)* 
464 D. R. Johnson et al., Needs Assessment for Nondestructive Testing and Materials Characterization for Improved Reliability in Structural Ceramics for Heat Engines, ORNL/TM-10354 (August 1987)*

465 S. J. Pruchnic, Jr., "Computer Interfacing of a Raman Spectroscopy Facility for Application to Quantitative Analyses of Crystalline Phases in TransformationToughened Ceramics," M.S. Thesis, Graduate Engineering and Research School of Engineering, University of Dayton, August $1987^{\dagger}$

466 S. Wahiduzzaman and T. Morel (Integral Technologies, Inc.), Effect of Translucence of Engineering Ceramics on Heat Transfer in Diesel Engines, ORNL/Sub/8622042/1 (October 1987)* 


\section{ALTERNATIVE FUELS UTILIZATION}

467 M. R. Swain, P. V. Scott and M. N. Swain, Waste Heat Recovery in a 1600 cc Methanol Fueled Engine; ORNL/Sub/85-27420/1 (January 1986)*

468 R. L. Graves and R. N. McGill, Alternative Fuels Utilization Program Project Office Operating Plan for FY 1985-86, ORNL/TM-9845 (January 1986)*

469 R. L. Graves, D. L. Greene and E. W. Gregory, Application of the Adiabatic Diesel to Heavy Trucks-A Technology Assessment, ORNL/TM-9554 (March 1986)*

470 R. N. McGill, ed., Federal Methanol Fleet Status-January 1986, ORNL/TM-10009 (May 1986)*

471 S. Vinyard (Southwest Res. Inst.), "Synthetic Fuel Operation in a Heavy Duty Diesel," SAE ${ }^{1}$ paper no. 861538, presented at the 1986 SAE International Fuels and Lubricants Meeting and Exposition, October 6-9, 1986, Philadelphia, Penn.*

472 R. Bair et al. (Univ. of Wisc.-Madison), "Diesel Combustion and Ignition Properties of Fuels with Different Volatile Fraction Constituents," SAE paper no. 861539, presented at the 1986 SAE International Fuels and Lubricants Meeting and Exposition, October 6-9, 1986, Philadelphia, Penn.*

473 K. E. Hankins et al. (Penn. St. Univ.), "Synthetic Fuel Performance, Combustion and Emissions' of a Light-Duty DI Diesel Engine," SAE paper no. 861540, presented at the 1986 SAE International Fuels and Lubricants Meeting and Exposition, October 6-9, 1986, Philadelphia, Penn.*

474 K. K. Rink and A. H. Lefebvre (Purdue Univ.), "Influence of Fuel Spray Characteristics and Operating Conditions on Pollutant Emissions," SAE paper no. 861541, presented at the 1986 SAE International Fuels and Lubricants Meeting and Exposition, October 6-9, 1986, Philadelphia, Penn.*

475 N. R. Sefer and J. Erwin (Southwest Res. Inst.), "Synthetic Gasolines and Diesel Fuels from Processing of Shale Oils and Coal Liquids," SAE paper no. 861542, presented at the 1986 SAE International Fuels and Lubricants Meeting and Exposition, October 6-9, 1986, Philadelphia, Penn.*

476 N. Scull, C. Kim, and D. E. Foster (Univ. of Wisc.-Madison), "A Comparison of Unburned Fuel and Aldehyde Emissions from a Methanol-Fueled Stratified Charge and Homogeneous Charge Engine," SAE paper no. 861543, presented at the 1986 SAE International Fuels and Lubricants Meeting and Exposition, October 6-9, 1986, Philadelphia, Penn.*

${ }^{1}$ Society of Automotive Engineers. 
477 F. F. Lyle, Jr., and H. C. Burghard, Jr. (Southwest Res. Inst.), "Effects of Natural Gas Contaminants on Corrosion in Compressed Natural Gas Storage Cylinders," SAE paper no. 861544, presented at the 1986 SAE International Fuels and Lubricants Meeting and Exposition, October 6-9, 1986, Philadelphia, Penn.*

478 S. Rajan (Southern Ill. Univ.), "Combustion, Emissions, and Fuel Distribution Characteristics of Synthetic Gasolines in Multicylinder Engines," SAE paper no. 861545, presented at the 1986 SAE International Fuels and Lubricants Meeting and Exposition, October 6-9, 1986, Philadelphia, Penn.*

479 R. N. McGill and E. E. Ecklund, "Introducing Methanol-Fueled Vehicles into Government Fleet Operations," presented at the Seventh International Symposium on Alcohol Fuels, Paris France, October 20-23, 1986*

480 R. L. Graves, W. K. Kahl and E. L. Long, "Testing of Developmental Ceramic Materials in Diesel Engine Combustion Chambers," ASME ${ }^{1}$ paper 87-ICE-28 (February 1987)*

481 D. E. Foster, C. Kim and N. Scull (Univ. Wisconsin), A Comparison of Unburned Fuel and Aldehyde Emissions from a Methanol-Fueled Stratified Charge and Homogeneous Charge Engine, ORNL/Sub/86-97366/1 (March 1987)*

482 R. L. Graves and R. N. McGill, Alternative Fuels Utilization Program Project Office Operating Plan for FY 1986-87, ORNL/TM-10435 (June 1987)*

483 R. L. Bechtold (Mueller Assoc.), Compendium of Significant Events in the Recent Development of Alcohol Fuels in the United States, ORNL/Sub/85-22007/1 (June 1987)*

484 R. N. McGill, S. L. Hillis and J. L. Wantland, Results from the First Year of Operation of the Federal Methanol Fleet at Lawrence Berkeley Laboratory, ORNL/TM-10485 (August 1987)*

485 J. W. Hodgson and J. C. Denny (Univ. Tenn.), Fuel Nitrogen Conversion in a Supercharged Spark Ignition Engine, ORNL/Sub/85-97367/1 (October 1987)*

486 D. E. Foster et al. (Univ. Wisc.), The Effects of Fuel Composition on Ignition Delay in Homogeneous Charge and Direct Injection Compression Ignition Engines, ORNL/Sub/84-89677/1 (November 1987)*

487 K. K. Rink, A. H. Lefebvre (Purdue Univ.) and R. L. Graves, "The Influence of Fuel Composition and Spray Characteristics on Soot Formation," SAE paper no. 872035, presented at the 1987 SAE International Fuels and Lubricants Meeting and Exposition, November 1987, Toronto, Ontario, Canada*

\footnotetext{
$1_{\text {American Society of Mechanical Engineers. }}$
} 
488 T. W. Ryan, III (Southwest Res. Inst.), "Ignition Delay as Determined in a Variable Compression Ratio Direct Injection Diesel Engine," SAE paper no. 872036, presented at the 1987 SAE International Fuels and Lubricants Meeting and Exposition, November 1987, Toronto, Ontario, Canada*

489 T. G. Buzza and T. A. Litzinger (Penn. St. Univ.), "A Comparison of Three Coal-Derived, Middle Distillate, Alternative Fuels in a Single-Cylinder DI Diesel Engine," SAE paper no. 872036, presented at the 1987 SAE International Fuels and Lubricants Meeting and Exposition, November 1987, Toronto, Ontario, Canada*

490 J. Erwin, N. R. Sefer (Southwest Res. Inst.) and B. Glavincevski (Natl. Res. Council-Canada), "Production and Analysis of EDS Coal-Derived Middle Distillate Test Fuels from Hydrogenation at Three Levels of Severity," SAE paper no. 872038, presented at the 1987 SAE International Fuels and Lubricants Meeting and Exposition, November 1987, Toronto, Ontario, Canada*

491 J. W. Hodgson (Univ. Tenn.), J, C. Denny (Sverdrup Tech.) and R. N. McGill, "Fuel Nitrogen Conversion in a Spark Ignition Engine," SAE paper no. 872039, presented at the 1987 SAE International Fuels and Lubricants Meeting and Exposition, November 1987, Toronto, Ontario, Canada*

492 M. R. Swain et al. (Univ. Miami), "The Effect of Alternative Gasolines on Knock and Intake Valve Sticking," SAE paper no. 872040, presented at the 1987 SAE International Fuels and Lubricants Meeting and Exposition, November 1987, Toronto, Ontario, Canada*

493 J. F. Wakenell, G. B. O'Neal (Southwest Res. Inst.) and Q. A. Baker (Wilfred Baker Engrg.), "High-Pressure Late Cycle Direct Injection of Natural Gas in a Rail Medium Speed Diesel Engine," SAE paper no. 872041, presented at the 1987 SAE International Fuels and Lubricants Meeting and Exposition, November 1987, Toronto, Ontario, Canada*

494 R. N. McGill, J. L. Wantland (ORNL) and S. L. Hillis (Univ. Tenn.), "First Year Results from the Federal Methanol Fleet at the Lawrence Berkeley Laboratory," SAE paper no. 872042, presented at the 1987. SAE International Fuels and Lubricants Meeting and Exposition, November 1987, Toronto, Ontario, Canada*

495 D. W. Dickey et al. (Southwest Res. Inst.), Engine Testing for Synfuel Operation, ORNL/Sub/85-28609/1 (January 1988)*

496 R. L. Bechtold (Mueller Assoc., Inc.), Status of Alcohol Fuels Utilization Technology for Highway Transportation: A 1986 Perspective. Volume II-Compression Ignition Systems, ORNL/Sub/85-22007/3 (January 1988)*

497 R. L. Bechtold (Mueller Assoc., Inc.), A Guide to the Planning and Management of Vehicle Fleet Tests to Obtain Significant Results, ORNL/Sub/85-22007/2 (February 1988)*

498 Mueller Associates, Inc., Status of Alcohol Fuels Utilization Technology for Highway Transportation: A 1986 Perspective, ORNL/Sub/85-22007/4 (February 1988)* 


\section{MICROEMULSION FUELS}

499 J. M. Googin, A. L. Compere and W. L. Griffith, "Technical Considerations in Choosing Alcohol Fuels for Less-developed Countries," Alternative Energy Sources $V$ D, pp. 173-86 (Hemisphere Press, 1983)*

500 W. L. Griffith and A. L. Compere, "Diesel Fuel Extenders and Substitutes," Energy and Environment, vol. 8 of National Conference on Resource Management, pp. 10-19 (CERMA Press, 1984)*

501 A. L. Compere, W. L. Griffith and J. M. Googin, "Integrated Palm Oil Processing," Alternative Energy Sources VI 2, pp. 515-22 (Hemisphere Press, 1984)*

502 W. L. Griffith, R. Triolo and A. L. Compere, "Analytical Structure Function of a Polydisperse Percus-Yevick Fluid with Schulz (gamma) Distributed Diameters," Physical Review A 33, pp. 2197-2200, 1986*

503 A. L. Compere, W. L. Griffith and J. M. Googin, "Stability and Composition of Palm, Coconut, and Soy Oil Fatty Acid Microemulsion Diesel Fuels," pp. 355-60 in Alternative Energy Sources VII D, pp. 355-60 (Hemisphere Press, 1986)*

504 W. L. Griffith, R. Triolo, and A. L. Compere, "Analytical Scattering Function of a Polydisperse Percus-Yevick Fluid with Schulz- (gamma-) Distributed Diameters," Physical Review A 35(5), pp. 2200-2206, March 1, 1987*

505 W. L. Griffith, J. M. Googin, and A. L. Compere, "Effect of Alcohols, Ketones, and Sodium Salts on the Extraction of 1-butanol from Aqueous Solution by the Ethyl Ester of Soybean Oil Fatty Acids," Separation Science and Technology 22(2,3), pp. $373-78,1987^{*}$

506 A. L. Compere, J. M. Googin and W. L. Griffith, "Effect of Possible Interferences on the Extraction of 1-butanol from Aqueous Solution by the Ethyl Esters of Soybean Oil Fatty Acids," Separation Science and Technology 22(2\&3), pp. $373-78,1987^{*}$

507 E. Caponetti, R. Triolo and J. S. Johnson, "Small-angle Neutron Scattering from Micelles of Aklylpolyoxyethylene Sulfate: Effect of Chain Length," J. Sol. Chem. 16(4), pp. 295-306 (1987)* 


\section{INDUSTRIAL CHEMICAL HEAT PUMPS}

508 H. Perez-Blanco, Heat Pump Concepts for Industrial Use of Waste Heat, ORNL/TM-7655 (May 1981) ${ }^{\dagger}$

509 H. Perez-Blanco and G. Grossman, Cycle and Performance Analysis of Absorption Heat Pumps for Waste Heat Utilization, ORNL/TM-7852 (September 1981) ${ }^{\dagger}$

510 G. Grossman, Simultaneous Heat and Mass Transfer in Absorption of Gases in Laminar Liquid Films, ORNL/TM-8366 (September 1982) ${ }^{\dagger}$

511 G. Grossman, Adiabatic Absorption and Desorption for Improvement of TemperatureBoosting Absorption Heat Pumps, ORNL/TM-8390 (November 1982) ${ }^{\dagger}$

512 G. Grossman and M. T. Heath, Simultaneous Heat and Mass Transfer in Absorption of Gases in Turbulent Liquid Films, ORNL/TM-8503 (July 1983) ${ }^{\dagger}$

513 G. Grossman (Technion-Israel Inst. Tech.), Multi-Stage Absorption Heat Pumps for Industrial Application-Final Report, ORNL/Sub/83-43337/1 (November 1984) ${ }^{\dagger}$

514 H. Perez-Blanco and L. Pan, Comparative First- and Second-Law Analysis of an Absorption Cycle, ORNL/TM-9595 (July 1985)*

515 S. I. Kaplan, ed., A Survey and Assessment of Chemical Heat Pumps, ORNL/TM-9544 (November 1985) ${ }^{\dagger}$

516 G. Grossman and E. Michelson (Technion-Israel Inst. Tech.), Multi-Stage Absorption Heat Pumps for Industrial Applications, ORNL/Sub/83-43337/2 (April 1986)*

517 H. Perez-Blanco and M. R. Patterson, Conceptual Design and Optimization of $a$ Versatile Absorption Heat Transformer, ORNL/TM-9841 (June 1986)*

518 W. F. Davidson and D. C. Erickson (Energy Concepts Co.), New High Temperature Absorbent for Absorption Heat Pumps, ORNL/Sub/85-22013/1 (July 1986)*

519 U. Rockenfeller and G. Horn (Desert Research Inst.), New Industrial Chemical Working Fluids. Final Report, ORNL/Sub/85-22014/1 (July 1986)*

520 R. L. Cox, Improvements and Enhancements of the Absorb Computer Program for Modeling Chemical Absorption Heat Pump Systems, ORNL/TM-9957 (July 1986)*

521 S. Hettiarachchi and M. Urquidi-Macdonald (SRI Intl.), Review of Chemical Heat Pump Solid/Vapor Working Media and Modeling: Final Report, ORNL/Sub/86-22038/1 (October 1986)*

522 M. R. Ally, Metal Hydride Temperature Amplifiers for High Temperature ( $>260^{\circ} \mathrm{C}$ ) Applications-A Parametric Study, ORNL/TM-10166 (December 1986)* 
523 M. R. Ally, Thermodynamic Properties of Aqueous Ternary Solutions Relevant to Chemical Heat Pumps. Final Report, ORNL/TM-10258 (March 1987)*

524 H. Perez-Blanco, M. R. Patterson and J. Braunstein, Ideal Fluid Properties for Optimizing Absorption Heat Pump Performance, ORNL/TM-10315 (April 1987)*

525 M. R. Ally, "Simulated Performance of Absorption Heat Pumps Using a Mixed Aqueous Nitrate Working Fluid," ASME paper no. 87-WA/AES-2 (Boston: American Society of Mechanical Engineers, December 1987)*

526 M. R. Ally, "Carnot Thermal Efficiencies of Chemical Heat Pumps Operating Between Four Temperature Levels-A Heuristic Approach," ASHRAE Trans 93(2) (Atlanta: American Society of Heating, Refrigerating, and Air Conditioning Engineers, 1987)*

527 M. R. Ally, "Design Considerations for Fixed-Bed Metal Hydride Heat Pumps for High Temperature Boosts," ASHRAE Trans 94(1) (Atlanta: American Society of Heating, Refrigerating, and Air Conditioning Engineers, 1988)* 


\section{MATERIALS FOR WASTE HEAT UTILIZATION}

$528 \mathrm{~J}$. I. Federer and V. J. Tennery, Effects of Alternate Fuels Refractory Test Facility Test 2: Evaluation of Magnesia-Based Bricks and Mortar and Alumina-Based Bricks, Castables, and Fibrous Insulations Exposed to Residual Oil Combustion Products, ORNL.TM-6840 (March 1980) ${ }^{\dagger}$

529 J. I. Federer and V. J. Tennery, Effects of Alternate Fuels, Report No. 8: Analysis of Degradation of Magnesia-Based Refractory Bricks from a Residual Oil-Fired Rotary Cement Kiln, ORNL/TM-7165 (May 1980) ${ }^{\dagger}$

530 J. I. Federer and V. J. Tennery, Effects of Alternate Fuels Refractory Test Facility Test 3: Part 1, Analysis of Alumina and Aluminosilicate Fibrous Insulations Exposed to the Combustion Products of No. 6 Residual Oil, ORNL/TM-7267 (May 1980) ${ }^{\dagger}$

531 Department of Energy, Ceramic Heat Recuperator for Industrial Heat Recovery, DOE/CS/40171-01 (May 1980) ${ }^{\dagger}$

532 J. I. Federer and V. J. Tennery, Corrosion of a Stainless Steel Waste Heat Recuperator, ORNL/TM-7166 (June 1980) ${ }^{\dagger}$

533 J. I. Federer and V. J. Tennery, Effects of Alternate Fuels Refractory Test Facility Test 3: Part 2, Analysis of Magnesia- and Alumina-Based Dense Refractories Exposed to the Combustion Products of No. 6 Residual Oil, ORNL/TM-7284 (July 1980) ${ }^{\dagger}$

534 J. I. Federer and V. J. Tennery, Analysis of a Corroded Stainless Steel Recuperator Used on a Glass Melting Furnace, ORNL/TM-7533 (November 1980)

535 V. J. Tennery, Economic Application, Design Analysis, and Material Availability for Ceramic Heat Exchangers, ORNL/TM-7580 (January 1981)

536 G. C. Wei and V. J. Tennery, Evaluation of Tubular Ceramic Heat Exchanger Materials in Residual Oil Combustion Environment, ORNL/TM-7578 (March 1981)

537 G. C. Wei, R. O. Williams and G. H. Llewellyn, "Brayton Cycle Heat Recovery for Container Glass Melting Furnace," pp. 624-31 in Proc. 16th Intersociety Energy Conversion Engineering Conference (August 1981) ${ }^{\dagger}$

538 R. O. Williams and A. E. Pasto, The Role of High Temperature Chemistry of Glass Furnace Atmospheres in Waste Energy Conversion," J. Am. Ceram. Soc. 65, pp. 602-606 (December 1981) ${ }^{\dagger}$

539 R. J. Lauf and C. S. Morgan, Ceramic-Metal Solid Electrolytes, ORNL/TM-8154 (March 1982)

540 J. I. Federer, Analysis of Refractory Fiber Insulations and Hot Face Coatings Exposed to Coal-Oil Mixture Combustion Products, ORNL/TM-8243 (July 1982) ${ }^{\dagger}$ 
541 G. C. Wei, "Beta SiC Powders Produced by Carbothermic Reduction of Sílica in a High-Temperature Rotary Furnace," Comm. of Am. Ceram. Soc., pp. C-111-13 (July 1983) ${ }^{\dagger}$

542 G. H. Llewellyn and G. C. Wei, Thermal Analysis and Air Leakage Evaluation of a Typical Container-Glass Furnace Regenerator with a Brayton Cycle Heat Recovery System, ORNL/TM-8429 (November 1982) ${ }^{\dagger}$

543 J. I. Federer, Corrosion of Fluidized-Bed Boiler Materials in Synthetic Flue Gas, ORNL/TM-8819 (November 1983) ${ }^{\dagger}$

544 G. C. Wei and C. L: White, "High Temperature Behavior of Pressureless Sintered $\mathrm{SiC}$ in a Steel Soaking Pit Environment," Bull. Am. Ceram. Soc. 63(7), pp. 890-93 $(1984)^{\dagger}$

545 G. C. Wei, C. R. Kennedy and L. A. Harris, "Synthesis of Sinterable SiC Powder by Carbothermic Reduction of Gel-Derived Precursors and Pyrolysis of Polycarbosilane," Bull. Am. Ceram. Soc. 63(8), pp. 1054-61 (1984) ${ }^{\dagger}$

546 M. A. Janney et al., Carbothermal Synthesis of Silicon Carbide, ORNL-6169 (May 1985) ${ }^{\dagger}$

547 J. I. Federer et al., Analysis of Candidate Silicon Carbide Recuperator Materials Exposed to Industrial Furnace Environments, ORNL/TM-9677 (July 1985) ${ }^{\dagger}$

548 J. I. Federer et al., Corrosion of SiC Ceramics in Synthetic Combustion Atmospheres Containing Halides, ORNL-6258 (December 1985) ${ }^{\dagger}$

549 J. I. Federer and A. J. Moorhead, Compilation of Information on Commercially Available Ceramic Coatings for High-Temperature Applications, ORNL/TM-9875 (December 1985) ${ }^{\dagger}$

550 J. 1. Federer and P. J. Jones, Oxidation/Corrosion of Metallic and Ceramic Materials in an Aluminum Remelt Furnace, ORNL/TM-9741 (December 1985) ${ }^{\dagger}$

551 J. 1. Federer, Corrosion of Materials by High-Temperature Industrial Combustion Environments-A Summary, ORNL/TM-9903 (February 1986)*

552 M. A. Janney et al., Bibliography of Ceramic Extrusion and Plasticity, ORNL-6363 (March 1987)*

553 P. T. B. Shaffer, K. A. Blakely (Advanced Refractory Techniques, Inc.) and M. A. Janney, "Production of Fine, High-Purity, Beta SiC Powder," Adv. Ceram. 21 , pp. $257-63(1987)^{\dagger}$

554 J. I. Federer, "Corrosion of $\mathrm{SiC}$ Ceramics by $\mathrm{Na}_{2} \mathrm{SO}_{4}, "$ Bull. Am. Ceram. Soc. 3(1), pp. 56-61 (January 1988) ${ }^{\dagger}$ 


\section{ENERGY CONVERSION AND UTILIZATION TECHNOLOGIES-MATERIALS}

555 G. C. Wei, "Beta-Silicon Carbide Powders Produced by Carbothermic Reproduction of Silicon in a High-Temperature Rotary Furnace," J. Am. Ceram. Soc. 66(7), pp. C111-13 (July 1983)

556 T. R. Curlee, The Economic Feasibility of Recycling Plastic Wastes: Preliminary Assessment, ORNL/TM-9098 (April 1984) ${ }^{\dagger}$

557 R. D. Deanin and A. R. Yniguez, "Recycling of the Mixed Plastics Fraction from Junked Autos, II. High-Pressure Molding," Am. Chem. Soc. Polym. Mat. Sci. Eng. 50, p. 413 (April 8-13, 1984) ${ }^{\dagger}$

558 C. T. Liu and N. S. Stoloff, Development and Characterization of Ductile LongRange-Ordered (LRO) Alloys, ( $\mathrm{Fe}, \mathrm{Co}, \mathrm{Ni})_{3} \mathrm{~V}$ for High-Temperature Structural Use, ORNL-6032 (August 1984) ( $^{\dagger}$

559 C. T. Liu et al., Initial Development of Nickel and Nickel-Iron Aluminides for Structural Uses, ORNL-6067 (August 1984) ${ }^{\dagger}$

560 L. E. Morris and J. A. Carpenter, Jr., Materials Project of the Energy Conversion and Utilization Technologies (ECUT) Program Progress Report for Year Ending September 30, 1982, ORNL/TM-8940 (August 1984)

561 R. O. Williams, Thermodynamics of Copper-Nickel Alloys Containing Aluminum, Silicon, Titanium, and Chromium Relative to their Use in Ceramic Brazing, ORNL-6072 (November 1984)

562 M. L. Santella et al. Welding Studies of Nickel Aluminide and Nickel-Iron Aluminides, ORNL-6194 (August 1985) ${ }^{\dagger}$

563 J. A. Horton, A. Das Gupta and C. T. Liu, "The Disordering Process in an L12 Ordered Alloy," Proceedings Second Annual Meeting of the Electron Microscopy Society of America, p. 486 (San Francisco Press, 1986) ${ }^{\dagger}$

564 T. R. Curlee, The Economic Feasibility of Recycling. A Case Study of Plastic Wastes (New York: Praeger Publishers, 1986) ${ }^{\dagger}$

565 J. J. Eberhardt, P. H. Hay and J. A. Carpenter, Jr., "Materials by Design: A Hierarchical Approach to the Design of New Materials," Proceedings of Symposium on Computer-Based Microscopic Description of the Structure and Properties of Materials, ed. J. Broughten et al., 63, pp. 191-206 (Materials Research Society, Pittsburgh, 1986) ${ }^{\dagger}$

566 C. T. Liu and V. K. Sikka, "Nickel Aluminides for Structural Use," J. Metals 38, pp. 19-21 (1986) ${ }^{\dagger}$ 
567 T. M. Besmann, "Thermodynamic Analysis of the Chemical Vapor Deposition of Composite $\left\langle\mathrm{Si}_{3} \mathrm{~N}_{4}\right\rangle-<\mathrm{BN}>$ Coatings," J. Amer. Ceram. Soc. $69(1986)^{\dagger}$

568 T. Konoike, Strengthening of Single Crystal Alpha-Alumina with Ion Implantation, Master's Thesis, Georgia Institute of Technology (August 1986) ${ }^{\dagger}$

569 J. K. Cochran et al., "Ion Implanted Precipitate Microstructure and Mechanical Properties of Ceramic Surfaces," J. Materials for Energy Systems 8(2), pp. 121-27 (Sept. 1986) ${ }^{\dagger}$

570 A. J. Moorhead and $H$. Keating, "Direct Brazing of Ceramics for Advanced Heavy-Duty Diesels," Weld. J. 65(10), pp. 17-31 (1986)

571 T. R. Curlee, "Plastics Recycling: Economic and Institutional Issues,". Conserv. Recycling 9(4), pp. 335-50 (1986) ${ }^{\dagger}$

572 A. J. Moorhead and P. F. Becher, "Development of a Test for Determining Fracture Toughness of Brazed Joints in Ceramic Materials," Weld. J. 66, pp. 26s32s (January 1987)

573 L. E. Morris, A. Jordan, and J. A. Carpenter, Jr., Annual Progress Report of the Materials Project of the Energy Conversion and Utilization Technologies (ECUT) Program for Fiscal Year 1983, ORNL/TM-9695 (February 1987)*

574 Plastics Institute of America, Inc., Secondary Reclamation of Plastics Waste Research Report-Phase I. Development of Techniques for Preparation and Formulation (Lancaster, Penn.: Technomic Publishing Company, Inc., 1987) ${ }^{\dagger}$

575 Plastics Institute of America, Inc., Secondary Reclamation of Plastics Waste Research Report-Phase II. Evaluation of Industrial Processes: Financial Analysis and Potential Markets (Lancaster, Penn: Technomic Publishing Company, Inc., 1987) ${ }^{\dagger}$

576 W. A. Simpson, Jr., and R. W. McClung, Ultrasonic Techniques for the Evaluation of Ceramic Joints, ORNL-6350 (April 1987)*

577 T. R. Curlee, "Plastics Recycling Faces Barriers," Waste Age 18(7), pp. 55-60 (July 1987) ${ }^{\dagger}$

578 H. Alan Fine, Applicability of Aerospace Thermal Insulation Technologies to the Civilian Sector, ORNL/Sub/86-55951/1 (October 1987)*

579 V. K. Sikka, "Processing Technology for Nickel Aluminides," Proceedings of the Materials Research Society Symposium, Boxton, December 1-6, 1986 81, pp. 48793 (Pittsburgh: Materials Research Society, 1987) ${ }^{\dagger}$

580 A. J. Moorhead, "Direct Brazing of Alumina Ceramics," Adv. Ceram. Mater. 2(2), pp. $159-66(1987)^{\dagger}$ 
581 A. J. Moorhead and P. F. Becher, "Adaptation of DCB Test for Determining Fracture Toughness of Brazed Joints in Ceramic Materials," J. Mater. Sci. 22(9), pp. 3297-3303 (1987) ${ }^{\dagger}$

582 C. T. Liu, E. H. Lee and T. J. Henson, Initial Development of High-Temperature Titanium Silicide Alloys, ORNL-6435 (January 1988)*

583 J. R. DiStefano, J. H. DeVan and L. C. Fuller, Assessment of Material Requirements for Advanced Steam Cycle Systems (>1100 F), ORNL/TM-10489 (February 1988)* 


\section{ENERGY CONVERSION AND UTILIZATION TECHNOLOGIES-TRIBOLOGY}

584 C. S. Yust, "Tribology and Wear,". Int. Met. Rev. 30(3), pp. 141-54 (1985) ${ }^{\dagger}$

585 C. S. Yust and F. J. Carignan, "Observations on the Sliding Wear of Ceramics," Am. Soc. Lubr. Eng. Trans. 28, pp. 245-52 (1985) ${ }^{\dagger}$

586 C. S. Yust et al., "Wear of Implanted $\mathrm{TiB}_{2}$ Surfaces," pp. 1-9, sect. 1.4.8 in Eurotrip 85, ed. M. Armbruster (Amsterdam: Elsevier, 1985) ${ }^{\dagger}$

587 C. S. Yust, S. M. Hsu and T. M. Levinson, Ceramic Tribology: Assessment of Needs in Measurement Methods and Standards, ORNL/TM-9921 (February 1986)*

588 C. J. McHargue et al., "Surface Mechanical Properties and Wear Behavior of Ion Implanted $\mathrm{TiB}_{2}, "$ pp. 803-12 in The Science of Hard Materials, ed. E. A. Almond, C. A. Brookes and R. Warren (Bristol: Institute of Physics, 1986) ${ }^{\dagger}$

589 C. J. McHargue et al., "Surface Property Modification of Ceramics by Ion Beams," Journal of Materials for Energy Systems 8(3), pp. 255-66 (1986) ${ }^{\dagger}$

590 J. A. Griffioen, S. Bair and W. O. Winer, "Infrared Surface Temperature Measurements in a Sliding Ceramic-Ceramic Contact," pp. 238-45 in Mechanisms and Surface Distress, ed. D. Dowson et al. (London: Butterworths, 1986) ${ }^{\dagger}$

591 S. Rao and C. R. Houska, "X-ray Diffraction Profiles Described by Refined Analytical Functions," Acta Crystallog. A42, pp. 14-19 (1986) ${ }^{\dagger}$

592 C. S. Yust, J. M. Leitnaker and C. E. DeVore, "Wear of an Alumina-Silicon Carbide Whisker Composite," Wear Mater. 1, pp. 277-83 (1987) ${ }^{\dagger}$

593 T. F. J. Quinn and W. O. Winer, "An Experimental Study of the Hot Spots Occurring During the Oxidational Wear of Tool Steel on Sapphire," J. Tribology $109(1987)^{\dagger}$ 


\section{EMERGENCY ENERGY CONSERVATION}

594 F. D. Boercker et al., Emergency Petroleum Conservation: A Review and Analysis of Selected Measures, ORNL/TM-7059 (January 1980) ${ }^{\dagger}$

595 N. E. Collins and J. H. Sorensen, Preliminary Considerations for State Energy Emergency Planning; ORNL/TM-7876 (March 1982) ${ }^{\dagger}$

596 M. V. Adler and V. A. Honkala, A Survey of Selected Local Government Energy Emergency Planning Programs, ORNL/TM-7976 (March 1982) ${ }^{\dagger}$ 
ENERGY RELATED INVENTIONS PROGRAM

597 M. L. Grad, L. M. Bronfman and E. J. Soderstrom, Evaluation of the EnergyRelated Inventions Program, Volume II: Analysis of Case Studies of Supported Projects, ORNL/CON-92/VII (May 1982) ${ }^{\dagger}$

598 M. L. Grad, L. M. Bronfman and E. J. Soderstrom, Evaluation of the EnergyRelated Inventions Program, Volume I: Analysis of Case Studies of Supported Projects, ORNL/CON-92/V1 (February 1983) ${ }^{\dagger}$

599 E. J. Soderstrom, L. M. Bronfman and M. L. Rorke, Energy-Related Inventions Program: An Overview of the Evaluation, ORNL/CON-92/VIII (September 1983) ${ }^{\dagger}$

600 E. J. Soderstrom et al., A Review of Alternative Services and Approaches for the Energy-Related Inventions Program, ORNL/CON-157 (December 1984) ${ }^{\dagger}$

601 M. A. Brown et al., Evaluation of the Energy-Related Inventions Program: An Empirical Analysis of 204 Inventions, ORNL/CON-225 (March 1987)* 


\section{ELECTRIC ENERGY SYSTEMS}

602 H. M. Long and P. N. Overholt, "Load Management from a Department of Energy Perspective, Proc. Winter Meeting IEEE ${ }^{1}$ Winter Meeting Power Apparatus and Systems, CONF-800218, pp. 1-7 (February 1980) ${ }^{\dagger}$

603 F. S. Ma, L. Isaksen and M. A. Kuliasha, "Impact of Thermal Storage on Electric Distribution Systems," IEEE Paper No. A-80-074-5 (February 1980) ${ }^{\dagger}$

604 M. A. Kuliasha, A Dynamic Model of Power System Operation Incorporating Load Control, ORNL-5655 (October 1980) ${ }^{\dagger}$

605 R. W. Boardman, R. Patton and D. H. Curtice (Systems Control, Inc.), Impact of Dispersed Solar and Wind Systems on Electric Distribution Planning and Operation, ORNL/Sub-7662/1 (February 1981) ${ }^{\dagger}$

606 R. Dybeck et al. (City of Burbank Publ. Svc. Dept.), Selective Load Control for Industrial Customers, ORNL/Sub-7399/1 (September 1981) ${ }^{\dagger}$

607 Energy Utilization Systems, Inc., Survey of Utility Load Management Projects, Third Revised Report, ORNL/Sub-80/13644/1 (October 1981) ${ }^{\dagger}$

608 D. T. Rizy, Utility Controlled Customer-Side Thermal Energy Storage Tests: Heat Storage, ORNL-5796 (February 1982) ${ }^{\dagger}$

609 B. R. Dewey, Thermal Stress Analysis of an Aluminum-Mylar Transformer Coil, ORNL/TM-8095 (February 1982) † $^{-}$

610 G. L. Campen, Results of the Harmonics Measurement Program at the John F. Long Photovoltaic House, ORNL-5834 (March 1982) ${ }^{\dagger}$

611 K. D. Van Liere et al., Public Reactions to Load Management: A Summary of Baseline Community Data for the Athens Automation and Control Experiment, ORNL/TM-7961 (June 1982) f.

612 C. E. Easterly et al, Health Effects of Dielectric Gases: Preliminary Report, ORNL/TM-8353 (August 1982) ${ }^{\dagger}$

613 D. T. Rizy, Personnel Safety Requirements for Electric Distribution Systems with Dispersed Storage and Generation, ORNL/TM-8455 (November 1982$)^{\dagger}$

614 W. T. Jewell, Advanced Power Conversion Concepts for HVDC Transmission Systems, ORNL-5898 (January 1983) ${ }^{\dagger}$

615 M. A. Kuliasha, Utility-Controlled Customer-Side Thermal Energy Storage Tests: Cool Storage, ORNL-5795 (February 1983) ${ }^{\dagger}$

\footnotetext{
${ }^{1}$ Institute of Electrical and Electronic Engineers.
} 
616 Y. Wang, A Dynamic Model for an Induction Motor and Its Verification, ORNL/Sub/79-7685/1\&40 (February 1983) ${ }^{\dagger}$

617 H. Nguyen, A New Aggregation Methodology Applied to Residential Air Conditioner Loads, ORNL/Sub/79-7685/2\&40 (February 1983) ${ }^{\dagger}$

618 R. J. Lauf, High-Voltage-Gradient Zinc Oxide Varistors: Fabrication and Properties, ORNL/TM-8484 (March 1983) ${ }^{\dagger}$

619 H. W. Zaininger and D. J. Bell (Zaininger Engineering Co.), Investigating Alternative Interconnection Strategies for Arrays of Wind Turbine Generators-Final Report, ORNL/Sub/82-69604/1 (July 1983) ${ }^{\dagger}$

620 R. C. Dugan (McGraw-Edison Co.), Computer Simulation Harmonics Study: Analysis of the Effects on Two Distribution Feeders of Harmonics Produced by the Proposed John F. Long 100-House Photovoltaic Development, ORNL/Sub/81-9500/1 (August 1983) ${ }^{\dagger}$

621 R. C. Dugan (McGraw-Edison Co.), Protection of Electric Distribution Systems with Dispersed Storage and Generation (DSG) Devices, ORNL/CON-123 (September 1983) ${ }^{\dagger}$

622 L. A. Johnson (General Electric Co.), Utilization of Amorphous Metals in Electric Motors, ORNL/Sub/81-70519/1 (October 1983) ${ }^{\dagger}$

623 R. Garzon (Brown Boveri Electric, Inc.), Development of a Solid-State Circuit Breaker Concept, ORNL/Sub/81-61623/1 (December 1983) ${ }^{\dagger}$

624 D. R. James et al., A Current Assessment of Research on Insulating Gas Mixtures and Their Potential for Industrial Applications, ORNL/TM-9017 (February 1984) ${ }^{\dagger}$

625 D. Curtice et al. (Systems Control, Inc.), Protection and Safety of Electric Distribution Systems with Dispersed Storage and Generation Devices, ORNL/Sub/807974/1 (April 1984) ${ }^{\dagger}$

626 P. R. Barnes, E. F. Vance and H. W. Askins, Jr., Nuclear Electromagnetic Pulse (EMP) and Electric Power Systems, ORNL-6033 (April 1984) ${ }^{\dagger}$

627 R. B. Biggs and W. T. Jewell, Summary of Multiterminal High-Voltage Direct Current Transmission Technology, ORNL/TM-8724 (May 1984) ${ }^{\dagger}$

628 H. R. Philipp, G. D. Mahan and L. M. Levinson (General Electric Co.), Advanced Metal Oxide Varistor Concepts, ORNL/Sub/84-17457/1 (July 1984) ${ }^{\dagger}$

629 F. A. McClintock et al. (Mass. Inst. Tech.), Assessing Expired Fatigue Life in Large Turbine Shafts, ORNL/Sub/83-9062/1 (July 1984) ${ }^{\dagger}$

630 J. D. Birdwell (Univ. Tenn.) et al., Issues in the Design of a Computer-Aided Systems and Control Analysis and Design Environment (CASCADE), ORNL/TM-9038 (August 1984) ${ }^{\dagger}$ 
631 D. T. Rizy, Protection and Safety Requirements for Electric Distribution Systems with Dispersed Storage and Generation (DSG) Devices, ORNL/CON-143 (August 1984) ${ }^{\dagger}$

632 H. W. Zaininger (Zaininger Engrg. Co.), Electromagnetic Pulse (EMP) Interaction with Electric Power Systems, ORNL/Sub/82-47905/1 (August 1984) ${ }^{\dagger}$

633 E. Richter (Corporate R\&D), Permanent Magnet Motors, ORNL/Sub/82-17452/1 (September 1984)

634 D. T. Rizy, W. T. Jewell and J. P. Stovall, Operational and Design Considerations for Electric Distribution Systems with Dispersed Storage and Generation (DSG), ORNL/CON-134 (September 1984) ${ }^{\dagger}$

635 I. Sauers et al., Spark Decomposition of $S F_{6}$; Toxicity of By-Products, ORNL/TM9062 (October 1984) ${ }^{\dagger}$

636 C. J. Heyne and A. M. El-Antably (Westinghouse), Reluctance and Doubly-Excited Reluctance Motors, ORNL/Sub/81-95013/1 (November 1984) ${ }^{\dagger}$

637 R. C. Dugan and D. T. Rizy, "Electric Distribution Protection Problems Associated with the Interconnections of Small, Dispersed Generation Devices," IEEE Trans. Power Appar. Syst. PAS-10, pp. 1121-27 (New York: IEEE, 1984) ${ }^{\dagger}$

638 H. E. McCoy, Jr., Evaluation of Polymer Films for Electrical Insulation, ORNL-6134 (April 1985) ${ }^{\dagger}$

639 J. R. Legro, N. C. Abi-Samra and F. M. Tesche (Westinghouse), Study to Assess the Effects of Magnetohydrodynamic Electromagnetic Pulse on Electric Power Systems Phase I, Final Report, ORNL/Sub/83-43374/1/V3 (May 1985) ${ }^{\dagger}$

640 P. A. Gnadt and S. P. Walldorf, Review and Evaluation of the Department of Energy's Research and Development Program for 1200-kV Transmission and Substation Equipment, ORNL/TM-9368 (June 1985) ${ }^{\dagger}$

641 R. J. Lauf, R. K. Williams and F. T. Greenwald, High-Field ZnO Varistors: Microstructures and Properties, ORNL/TM-9378 (June 1985) ${ }^{\dagger}$

642 H. W. Zaininger and G. M. Jaszewski (Zaininger Engrg. Co.), HEMP Interaction with an Electric Power Distribution Circuit, ORNL/Sub/84-73986/2 (August 1985) ${ }^{\dagger}$

643 N. Engheta et al. (Kaman Sciences Corp.), HEMP-Induced Transients in Transmission and Distribution (T\&D) Lines, ORNL/Sub/84-73986/1 (September 1985) ${ }^{\dagger}$

644 J. R. Legro et al. (Westinghouse), Study to Assess the Effects of Electromagnetic Pulse on Electric Power Systems, Phase I Executive Summary, ORNL/Sub/8343374/1/V1 (September 1985) ${ }^{\dagger}$

645 J. R. Legro et al. (Westinghouse), Study to Assess the Effects of Nuclear Surface Burst Electromagnetic Pulse on Electric Power Systems, Phase I Final Report, ORNL/Sub/83-43374/1/V4 (September 1985) ${ }^{\dagger}$ 
646 J. H. Reed et al., Test Plan for the Load Control Experiments, Athens Automation and Control Experiment, ORNL/TM-9796 (September 1985) ${ }^{\dagger}$

647 E. Sonder, T. C. Quinby and D. L. Kinser, ZnO Varistors Made From Powders Produced Utilizing a Urea Process, ORNL/TM-9728 (September 1985) ${ }^{\dagger}$

648 R. Dethlefsen (Maxwell Labs), Design Concepts for a Pulse Power Test Facility to Simulate EMP Surges. Part II-Slow. Pulses, ORNL/Sub/84-89642/2 (October $1985)^{\dagger}$

649 I. D. Smith et al. (Pulse Science, Inc.), Study to Simulate High Altitude EMP Surges Induced in Overhead Power Lines, ORNL/Sub/84-89643/1 (November 1985) ${ }^{\dagger}$

650 T. M. Aldrich and C. E. Easterly, A Handbook of Epidemiological Methods with Special Emphasis on ELF Electromagnetic Fields, ORNL-6237 (November 1985) ${ }^{\dagger}$

651 S. L. Purucker et al., Athens Automation and Control Experiment, Project Review Meeting, Dallas, Texas, December 5-6, 1984, ORNL/TM-9758 (December 1985) ${ }^{\dagger}$

652 A. Rodriguez (Univ. So. Calif.) et al., "Effect of Insulator Surface Temperature on the Flashover Voltage of Outdoor Insulators," Proc. 17th Electrical/Electronic Insulation Conference, Boston, Sept. 30-Oct. 3, 1985, pp. 56-61 (1985) ${ }^{\dagger}$

653 E. M. Thomson et al. (Univ. Fla.-Gainesville), "Horizontal Electric Fields from Lightning Return Strokes," Proc. Int. Aerosp. Ground Conf. Lightning and Static Electricity, Paris, June 1985, pp. 167-73 (1985)

654 I. Sauers et al., "Gas Phase Hydrolysis of Sulfur Tetrafluoride; A Comparison of the Gaseous and Liquid Phase Rate Constants," J. Chem. Phys. 83(5), p. 2618 $(1985)^{\dagger}$

655 F. A. Modine et al., "Laser Fabrication of Electrodes on Zinc Oxide Varistors," J. Appl. Phys. 57, p. $5066(1985)^{\dagger}$

656 E. Sonder, L. M. Levinson and W. Katz, "The Role of Short-Circuiting Pathways in Reduced ZnO Varistors," J. Appl. Phys. 58, p. $4420(1985)^{\dagger}$

657 D. Curtice et al. (Systems Control, Inc.), Cost/Risk Trade-Offs of Alternate Protection Schemes for Small Power Sources Connected to an Electric Distribution System, ORNL/Sub/81-16957/1 (January 1986)*

658 A. Ramrus (Maxwell Labs), Design Concepts for a Pulse Power Test Facility to Simulate EMP Surges in Overhead Power Lines, Part I Fast Pulse, ORNL/Sub/8489642/1 (February 1986)*

659 J. R. Legro et al. (Westinghouse), Study to Assess the Effects of High-Altitude Electromagnetic Pulse on Electric Power Systems, Phase I Final Report, ORNL/Sub/83-43374/1/V2 (February 1986)*

660 McGraw-Edison Power Systems, Power System Harmonics Seminar Notebook, ORNL/Sub/81-95011/2 (May 1986)* 
661 S. L. Purucker et al,, Athens Automation and Control Experiment; Substation and Distribution Systems Automation Designs and Costs, ORNL/TM-9596 (June 1986)*

662 C. M. Cooke et al. (Mass. Inst. Tech.), Research on Factors That Affect the Reliability of Compressed Gas Insulated Apparatus, ORNL/Sub/80-7979 (July 1986)*

663 S. D. Braithwait et al., Athens Automation and Control Experiment Project Review Meeting, Knoxville, Tennessee, December 3-5, 1985, ORNL/TM-10021 (August 1986)*

664 T. L. Simpson and C. W. Brice III (Univ. So. Car.), Measured Electrical Field Data (TVA's $500 \mathrm{kV}$ Transmission Lines) Normalized and Tabulated with Terrain Characterization Parameters, ORNL/Sub/85-00200/1 (October 1986)*

665 I. Sauers, "Sensitive Detection of By-Products Formed in Electrically Discharged Sulfur Hexafluoride," IEEE Trans. Electr. Insul. EI-21(2), pp. 105-10 (1986) ${ }^{\dagger}$

666 F. Flores, P. M. Echenique and R. H. Ritchie, "Energy Dissipation in the Scanning Tunneling Microscopy of Metals and Insulators," Phys. Rev. B 34, p. $2899(1986)^{\dagger}$

667 A. Gras Marti, P. M. Echenique and R. H. Ritchie, "Tunneling from a Self-Energy Approach," Conference Record of the 1986 IEEE International Symposium on Electrical Insulation, p. 125 (New York: IEEE Publ. Services, 1986) ${ }^{\dagger}$

668 . S. M. Spyrou, I. Sauers and L. G. Christophorou, "Dissociative Electron Attachment to $\mathrm{SO}_{2}, "$ J. Chem. Phys. 84(1), p. 239-43 (1986) ${ }^{\dagger}$

669 R. J. Van Brunt (NBS) and I. Sauers, "Gas-Phase Hydrolysis of SOF Sand $_{2}$ SOF J. Chem. Phys. 85(8), p. 4377-80 (1986) ${ }^{\dagger}$

670 1. Sauers, "Gas-Insulated Substations," Technology and Practice, ed. S. A. Boggs, F. Y. Chu and N. Fujimoto, p. 551 (New York: Pergamon Press, 1986) ${ }^{\dagger}$

671 L. M. Burrage et al. (McGraw-Edison Power Systems), Assess the Impact of the Steep-Front, Short Duration Impulse on Electric Power System Insulation. Phase I-Final Report, ORNL/Sub/85-28611/1 (February 1987)*

672 C. L. Longmire, R. M. Hamilton and J. M. Hahn (Mission Research Corp.), $A$ Nominal Set of High-Altitude EMP Environments, ORNL/Sub/86-18417/1 (February 1987)*

673 J. P. Stovall et al., Comparison of Costs and Benefits for DC and AC Transmission, ORNL-6204 (February 1987)*

674 H. M. Pflanz (Phoenix Elec. Corp.), Fault Current Limiter for Generator Bus Protection (27 kV, 600 A, $330 \mathrm{kA}$ ), ORNL/Sub/82-1743/1 (March 1987)*

675 S. P. Walldorf, Review and Evaluation of the Department of Energy's Research and Development Program for Solid Dielectric and Synthetic Laminar Cable Insulations 1975-1986, ORNL/Sub/83-39099/1 (March 1987)* 
676 T. D. Younkins (General Electric Co.), Methodology for Control and Operation' of Wind Arrays in Utility Systems, ORNL/Sub/81-7242/1 (April 1987)*

677 D. T. Rizy, E. W. Gunther and M. F. McGranaghan, "Transient and Harmonic Voltages Associated with Automated Capacitor Switching on Distribution Systems," IEEE Trans. Power Systems PWRS-2(3), pp. 713-23 (New York: IEEE, August 1987) ${ }^{\dagger}$

678 J. P. Blanchard, F. M. Tesche (LuTech, Inc.) and B. W. McConnell, The Effects of Corona on Current Surges Induced on Conducting Lines by EMP: A Comparison of Experiment Data with Results of Analytic Corona Models, ORNL/Sub/8527461/1 (September 1987)*

679 McGraw-Edison Power Systems, Electric Power System Harmonics Design Guide, ORNL/Sub/81-95011/3 (September 1987)*

680 D. M. Kroeger et al., "Retardation of Annealing Embrittlement in Iron-Based Glasses by Microaddition of Cerium," Acta Metall. 35, pp. 989-1000 (1987) ${ }^{\dagger}$

681 I. Sauers, "SOF 4 Production in Spark-Breakdown of $\mathrm{SF}_{6} / \mathrm{O}_{2}$ Mixtures," Gaseous Dielectrics V, ed. L. G. Christophorou and D. W. Bouldin, pp. 205-12 (New York: Pergamon Press, 1987) ${ }^{\dagger}$

682 G. Griffin et al., "Investigations of the Toxicological Action of Spark-Decomposed $\mathrm{SF}_{6}$ in Mammalian Cells," Gaseous Dielectrics $V$, ed. L. G. Christophorou and D. W. Bouldin, pp. 174-81 (New York: Pergamon Press, 1987) ${ }^{\dagger}$

683 F. A. Modine and R. B. Wheeler, "Fast Pulse Response of Zinc Oxide Varistors," J. Appl. Phys. 61, p. $3093(1987)^{\dagger}$

684 C. E. Easterly, T. E. Aldrich and M. D. Morris, "ELF Bioeffects: Use of Negative Data in a Structured Argument," Proc. 23rd Hanford Life Sciences Symposium, Richland, Washington, October 2-4, 1984, pp. 543-52 (Richland, Wash.: Pacific Northwest Laboratory, 1987) ${ }^{\dagger}$ 


\section{THERMAL ENERGY STORAGE}

685 D. M. Eissenberg and H. W. Hoffman, Thermal Energy Storage Program Annual Operating Plan FY 1980: Building Heating and Cooling Applications, ORNL/TM-7082 (January 1980) ${ }^{\dagger}$

686 F. J. Molz, A. D. Parr and P. F. Andersen (Auburn Univ.), Experimental Study of the Storage of Thermal Energy in Confined Aquifers, Final Report July 1977December 1979, ORNL/Sub-7338/1 (May 1980) ${ }^{\dagger}$

687 J. E. Davison and I. O. Salyer (Univ. Dayton), Electron Beam Irradiation of High Density Polyethylene Pellets for Thermal Energy Storage, ORNL/Sub-7641/1 (May 1980)

688 D. M. Eissenberg and C. Wyman, "Use of Phase Change Materials for Solar Applications," Solar Age 5, pp. 12-16 (May 1980)*

689 D. M. Eissenberg, "Building Heating and Cooling Applications Thermal Energy Storage Overview," Fourth Annual Review Meeting on Thermal Energy Storage, CONF-791232 (1980)*

690 J. F. Martin, "Subcontracted Activities Related to Thermal Energy Storage for Building Heating and Cooling," Fourth Annual Review Meeting on Thermal Energy Storage, CONF-791232 (1980) ${ }^{\dagger}$

691 R. J. Kedl, "In-House Activities Related to Thermal Energy Storage for Building Heating and Cooling," Fourth Annual Review Meeting on Thermal Energy Storage, CONF-792132 (1980) ${ }^{\dagger}$

692 M. P. Ternes, "Thermal Energy Storage Test Facility," Fourth Annual Review Meeting on Thermal Energy Storage; CONF-791232 (1980) ${ }^{\dagger}$

693 A. D. Solomon, "Mathematical Modeling of Moving Boundary Problems in Thermal Energy Storage," Fourth Annual Review Meeting on Thermal Energy Storage, CONF-791232 (1980) ${ }^{\dagger}$

694 J. F. Martin and H. W. Hoffman, Thermal Energy Storage for Building Heating and Cooling Applications-Technical Progress Report for Period April 1979 to March 1980, ORNL/TM-7319 (June 1980) ${ }^{\dagger}$

695 G. R. Frysinger (Univ. Delaware), Life and Stability Testing of Packaged Low-Cost Energy Storage Materials, ORNL/Sub-7585/1 (July 1980) ${ }^{\dagger}$

696 J. Braunstein, S. Cantor and C. E. Vallet, Physical Chemistry of Molten Salt Batteries Final Report for Period October 1, 1979-September 30, 1980: CurrentInduced Composition Gradients in Molten LiCl-KCl, ORNL/TM-7639 (March 1981) ${ }^{\dagger}$ 
697 J. F. Martin et al., Thermal Energy Storage for Building Heating and Cooling and Industrial Applications Technical Progress Report for Period March 1980 through April 1981, ORNL/TM-7779 (May 1981) ${ }^{\dagger}$

698 R. J. Borkowski et al., Energy Storage Using Phase-Change Materials for Active Solar Heating and Cooling: An Evaluation of Future Research and Development Direction, ORNL/TM-8098 (April 1982) ${ }^{\dagger}$

699 J. F. Martin et al., Thermal Energy Storage Technical Progress Report for Period April 1981 through March 1982, ORNL/TM-8350 (June 1982)

700 J. Braunstein, C. E. Vallet, and D. E. Heatherly, Physical Chemistry of Molten Salt Batteries Final Report for Period October 1, 1980-September 1982: CurrentInduced Composition Gradients in Molten LiCl-KCl, ORNL/TM-8489 (October 1982) ${ }^{\dagger}$

701 M. Olszewski and R. S. Steele, Fixed-Base Flywheel Storage Systems for Electric Utility Applications-An Assessment of Economic Viability and R\&D Priorities, ORNL/TM-8391 (February 1983) ${ }^{\dagger}$

702 C. E. Vallet et al., Physical Chemistry of Molten Salt Batteries Final Report for Period October 1, 1981-September 30, 1982: LiCl Precipitation from LiCl-KCl Anolyte in Porous LI-Al Electrodes, ORNL/TM-8714 (May 1983) ${ }^{\dagger}$

703 M. Olszewski and E. C. Fontana, Heat Pump Desuperheaters for Supplying Domestic Hot Water-Estimation of Energy Savings and Economic Viability for Residential Application, ORNL/CON-114 (May 1983) ${ }^{\dagger}$

704 J. Chen, R. Nelson, and F. Polinski, Pelletization and Roll Encapsulation of Thermal Energy Storage Materials, Final Report September 30, 1980-December 31, 1981, ORNL/TM-8543 (April 1983) ${ }^{\dagger}$

705 M. W. Wildin (Univ. of New Mexico), Results from Use of Thermally Stratified Water Tanks to Heat and Cool the Mechanical Engineering Building at the University of New Mexico, ORNL/Sub/80-7967/1 (June 1983) ${ }^{\dagger}$

706 M. Olszewski, Mechanical Energy Storage Technology Program FY 1982 Technical Progress Report, ORNL/TM-8765 (July 1983) ${ }^{\dagger}$

707 J. F. Martin et al., Thermal Energy Storage Technical Progress Report April 1982-March 1983, ORNL/TM-8780 (June 1983) ${ }^{\dagger}$

708 O. J. Whittemore (Univ. Wash.-Seattle), Unfired Olivine Heat Storage Media, ORNL/Sub/81-9063/1 (October 1983) ${ }^{\dagger}$

709 J. F. Martin et al., Thermal Energy Storage Technical Progress Report April 1983-March 1984, ORNL/TM-9170 (October 1984) ${ }^{\dagger}$

710 J. S. Johnson, Jr., and C. G. Westmoreland, Chemical Reactions Possibly Useful for Low Temperature Thermal Energy Storage, ORNL/TM-8963 (November 1983) ${ }^{\dagger}$ 
711 J. Braunstein, Research Opportunities in Salt Hydrates for Thermal Energy Storage, ORNL/TM-8840 (November 1983) ${ }^{\dagger}$

712 G. A. Geist et al., PCMSOL-1-A Computer Simulation Code for a Direct Gain Passive Solar Structure. Part I, Theory and Basic Relations, ORNL/CSD-127/P1 (February 1984) ${ }^{\dagger}$

713 G. A. Geist et al., PCMSOL-1-A Computer Simulation Code for a Direct Gain Passive Solar Structure. Part II, Users Guide, ORNL/CSD-127/PII (February 1984) ${ }^{\dagger}$

714 M. P. Ternes, Results on the Characterization of Gas Hydrate Formation in $a$ Direct Contact Heat Pump Cool Storage System, ORNL/TM-9212 (July 1985)*

715 J. F. Martin, Thermal Energy Storage Technical Progress Report April 1984-March 1985, ORNL/TM-9819 (January 1986)*

716 J. J. Carbajo, "A Direct-Contact-Charged, Direct-Contact-Discharged Cool Storage System Using a Gas Clathrate," ASHRAE Trans. 91(2B) (February 1986)*

717 S. R. Brown et al. (Lockheed Missiles and Space Co.), Experimental and Analytical Verification of PCMSOL, ORNL/Sub/81-17460/2 (March 1986)*

718 U. Rockenfeller (Desert Research Inst.), Development of Dual Temperature Ammines for Heat Pump Latent Heat Storage Application, ORNL/Sub/84-47999/1 (March 1986)*

719 A. D. Solomon et al., The Development of a Simulation Code for Latent Heat Thermal Energy Storage System in a Space Station, ORNL-6213 (April 1986)*

720 U. Rockenfeller (Desert Research Inst.), Development of Ammonia-Sodium Bromide Heat Pump/Dual Temperature Storage Concept. Final Report, ORNL/Sub/84-47999/2 (October 1986)*

721 W. Thacker, "The Kinetics of the Metallothermic Reduction of Amorphous Silica in the Presence of Liquid Aluminum-Silicon Alloys in the Temperature Range 1023 to $1323 \mathrm{~K}$," Master's Thesis, The Ohio State University (1986) ${ }^{\dagger}$

722 R. J. Petri, E. T. Ong (Inst. Gas Technology) and J. Martin, "High Temperature Composite Thermal Energy Storage (TES) Systems for Industrial Applications," Advancing Toward Technology Breakout in Energy Conversion, Proc. 21st Intersociety Energy Conversion Engineering Conference 2, pp. 873-80 (1986) ${ }^{\dagger}$

723 U. Rockenfeller (Rocky Research Corp.) and J. F. Martin, "Dual Temperature Thermal Storage with Complex Compounds," Advancing Toward Technology Breakout in Energy Conversion, Proc. 21st Intersociety Energy Conversion Engineering Conference 2, pp. 755-59 (1986) ${ }^{\dagger}$

724 J. F. Martin, Thermal Energy Storage Technical Progress Report April 1985-March 1986, ORNL/TM-10247 (February 1987)* 
725 L. I. Stiel (Polytech. Univ.-Brooklyn), Heats of Mixing for Thermal Energy Storage Systems, Phase I: Selection of Suitable Liquid-Liquid Mixtures, ORNL/Sub/86-27470/1 (July 1987)* 


\section{BIOFUELS PRODUCTION}

726 J. H. Cushman and J. W. Ranney, Short Rotation Woody Crops Program-Quarterly Report for Period Ending May 31, 1981, ORNL/TM-8156 (April 1982) ${ }^{\dagger}$

727 J. H. Cushman and J. W. Ranney, Short Rotation Woody Crops Program-Quarterly Report for Period Ending August 31, 1981, ORNL/TM-8157 (April 1982) ${ }^{\dagger}$

728 J. W. Ranney and J. H. Cushman, Short Rotation Woody Crops Program: Annual Progress Report for 1981, ORNL/TM-8120 (July 1982) ${ }^{\dagger}$

729 J. F. McBrayer et al., Generic Environmental Assessment Report for Conventional Fuel-Alcohol Plant, ORNL/TM-7993 (July 1982) ${ }^{\dagger}$

730 D. C. West and L. K. Mann, Whole-tree Harvesting Third Year Progress Report for 1981-Nutrient Depletion Estimates and Post-Harvest Impacts on Nutrient Dynamics, ORNL/TM-8335 (September 1982) ${ }^{\dagger}$

731 J. W. Ranney, J. H. Cushman and J. L. Trimble, The Short Rotation Woody Crops Program: 1982 Program Summary, ORNL-5916 (September 1982) ${ }^{\dagger}$

732 S. B. Land, Jr. (Miss. St. Univ.), Genetic Selection of American Sycamore for Biomass Production in the Mid-South: Final Report for the Period March 9, 1979-May 31, 1982, ORNL/Sub/81-9051/1 (September 1982) ${ }^{\dagger}$

733 D. J. Bjornstad et al., The On-Farm Use of Biomass Fuels: Market Penetration Potential During Normal and Fuel Emergency Conditions, ORNL-5894 (December 1982) ${ }^{\dagger}$

734 J. H. Cushman et al., Short Rotation Woody Crops Program: Annual Progress Report for 1982, ORNL-5973 (August 1983) ${ }^{\dagger}$

735 D. L. Rockwood et al. (Univ. Fla.-Gainesville), Energy and Chemicals from Woody Species in Florida. Final Report for the Period April 17, 1978-May 16, 1983, ORNL/Sub/81-9050/1 (September 1983) ${ }^{\dagger}$

736 W. Barron et al., Firstcut: A Preliminary Assessment Model for Short-Rotation Intensive Silviculture-Model Description and User's Guide, ORNL/TM-8566 (November 1983) ${ }^{\dagger}$

737 D. C. West and L. K. Mann, Whole-Tree Harvesting: Fourth Year Progress Report for 1982-Nutrient Depletion Estimates, Postharvest Impacts on Nutrient Dynamics and Regeneration, ORNL/TM-8805 (December 1983) ${ }^{\dagger}$

738 J. W. Ranney et al, Short Rotation Woody Crops Program Annual Progress Report for 1983, ORNL-6085 (September 1984) ${ }^{\dagger}$

739 L. L. Wright et al., Short Rotation Woody Crops Program Quarterly Progress Report for the Period September 1 to November 30, 1984, ORNL/TM-9540 (April 1985) ${ }^{\dagger}$ 
740 J. W. Ranney et al., Short Rotation Woody Crops Program: Annual Progress Report for 1984, ORNL/TM-6160 (August 1985) ${ }^{\dagger}$

741 L. L. Wright et al., Short Rotation Woody Crops Program Quarterly Progress Report for the Period March 1 to May 31, 1985, ORNL/TM-9698 (August 1985) ${ }^{\dagger}$

742 J. H. Cushman; J. L. Elmore and A. F. Turhollow, Herbaceous Energy Crops Program: Annual Progress Report for 1984, ORNL-6221 (November 1985) ${ }^{\dagger}$

743 L. L. Wright et al., Short Rotation Woody Crops Program Quarterly Progress Report for the Period June 1 to August 31, 1985, ORNL/TM-9832 (December 1985) ${ }^{\dagger}$

744 J. J. Fillatti et al., "The Introduction and Expression of a Gene Conferring Tolerance to the Herbicide Glyphosate in Populus NC-5339," Proceedings, TAPPI Research and Development Conference, Raleigh, NC, pp. 83-84 (1986)*

745 P. E. Heilman and R. F. Stettler (Univ. Wash.-Seattle), "Nutritional Concerns in Selection of Black Cottonwood and Hybrid Clones for Short Rotation," Can. J. For. Res. 16, pp. 860-63 (1986)*

746 K. A. Mahler and D. L. Auld, "Development and Uses of Winter Rapeseed Adapted to the Southeastern United States," Proceedings, Sixth Annual Solar, Biomass, and Wind Energy Workshop, Tifton, Georgia, pp. 167-70 (1986)*

747 D. J. Parrish et al. (VPISU), "Perennial Herbaceous Biomass Species for the Piedmont," Proceedings, Sixth Annual Solar, Biomass, and Wind Energy Workshop, Tifton, Georgia, pp. 60-65 (1986)*

748 K. V. Rao and G. W. Fick, "A Simple Simulation Model for Dry Matter Accumulation in Corn and Sudangrass," Agron. Abstr., p. 18 (1986)* $^{*}$

749 C. R. Ridge et al., "Leaf Growth Characteristics of Fast Growing Poplar Hybrids (Populus trichocarpa x P. deltoides)," Tree Physiology 1, pp. 209-16 (1986)*

750 J. R. Schutt, H. H. Shugart and J. W. Ranney, Crown Geometry of Plantation-Grown American Sycamore and Its Simulation, ORNL/TM-9721 (February 1986)*

751 P. R. Blankenhorn et al. (The Penn. St. Univ.), Net Financial and Energy Analysis for Producing Populus Hybrid Under Four Management Strategies. First Rotation, ORNL/Sub/79-07928/1 (April 1986)*

752 J. H. Cushman, A. F. Turhollow and J. W. Johnston, Herbaceous Energy Crops Program: Annual Progress Report for FY 1985, ORNL-6263 (April 1986)*

753 J. W. Ranney et al., Short Rotation Woody Crops Program: Annual Progress Report for 1985, ORNL-6254 (May 1986)*

754 G. D. Mroz et al. (Mich. Tech. Univ.), Application of Sugar Maple and Black Locust to the Biomass/Energy Plantation Concept. Final Report April 1984, ORNL/Sub/819058/3 (August 1986)* 
755 M. S. Salk and A. G. Folger, Characterization of the Southwest United States for the Production of Biomass Energy Crops, ORNL/TM-10203 (March 1987)*

756 J. H. Cushman, A. F. Turhollow and J. W. Johnston, Herbaceous Energy Crops Program: Annual Progress Report for FY 1986, ORNL-6369 (May 1987)*

757 J. W. Ranney et al., Short Rotation Woody Crops Program: Annual Progress Report for 1986, ORNL-6348 (November 1987)*

758 J. R. Krummel (Argonne Natl. Lab.) et al., "Landscape Patterns in a Disturbed Environment;" OIKOS 48, pp. 321-24 (1987)

759 J. W. Ranney, L. L. Wright and P. A. Layton, "Hardwood Energy Crops: The Technology of Intensive Culture, J. For. 85, pp. 17-28 (1987) ${ }^{\dagger}$

760 R. A. McLaughlin, E. A. Hansen and P. E. Pope, "Biomass and Nitrogen Dynamics in an Irrigated Hybrid Poplar Plantation," Forest Ecology and Management 18, pp. $169-88(1987)^{\dagger}$

761 J. R. Cowles and H. W. Scheid (Univ. Houston), Cultural and Management Practices for the Chinese Tallow Tree as a Biomass Fuel Source, ORNL/Sub/81-09059/1 (December 1987)* 


\section{BIOTECHNOLOGY}

762 W. W. Pitt and R. K. Genung, "Energy Conservation and Production in a Packed-Bed Anaerobic Bioreactor," Proceedings of Symposium on Energy from Biomass and Wastes, Lake Buena Vista, Florida (January 1980) ${ }^{\dagger}$

763 E. Greenbaum, "Simultaneous Photoproduction of Hydrogen and Oxygen by Photosynthesis," Biotech. Bioeng. Symp. 10, pp. 1-13 (New York: John Wiley \& Sons, 1980) ${ }^{\dagger}$

764 W. W. Pitt and J. E. Mrochek, Advanced Technology Section Semiannual Progress Report for the Period April 1, 1977 to September 30, 1977, Vol. 1: Biotechnology and Environmental Programs, ORNL/TM-6328/V1 (June 1980)

765 R. K. Genung et al., "Energy Conservation and Scale-up Studies for a Wastewater Treatment System Based on a Fixed-Film, Anaerobic Bioreactor," Biotech. Bioeng. Symp. 10 (New York: John Wiley \& Sons, 1980) ${ }^{\dagger}$

766 C. D. Scott, ed., "Proceedings of the Second Symposium on Biotechnology in Energy Production and Conservation," Biotech. Bioeng. Symp. 10 (New York: John Wiley \& Sons, 1980 ${ }^{\dagger}$

767 E. Greenbaum, "Hydrogen Production by Photosynthesis," presented at the Fifth Annual Institute of Gas Technology Meeting on Energy from Biomass and Wastes, Lake Buena Vista, Florida (January 26-30, 1981)*

768 E. Greenbaum, "Using Plants for Hydrogen Production," presented at the Annual Meeting of the Southern Section of the American Society of Plant Physiologists, Atlanta, Georgia (February 1-3, 1981)*

769 E. Greenbaum et al., "Photoproduction of Hydrogen and Oxygen," The BioEnergy Directory, 4th ed, p. $264(1981)^{\dagger}$

770 C. D. Scott, C. W. Hancher and E. J. Arcuri, "Tapered Fluidized-Bed Bioreactor for Environmental Control and Fuel Production," p. 651 in Advances in Biotechnology 1, ed. M. Moo-Young (Pergamon Press, 1981) ${ }^{\dagger}$

771 E. Greenbaum, "Stoichiometry of Hydrogen and Oxygen Photoproduction by Chloroplasts, Ferredoxin and Hydrogenase," Advances in Biotechnology 2, ed. M. Moo-Young and C. W. Robinson (Pergamon Press, 1981) ${ }^{\dagger}$

772 E. Greenbaum, "Limiting Reactions in Biosolar Hydrogen Production," Biotech. Bioeng. Symp. 11, pp. 581-91 (New York: John Wiley \& Sons, 1981) ${ }^{\dagger}$

773 C. K. Scott, ed., "Proceedings of the Third Symposium on Biotechnology in Energy Production and Conservation," Biotech. Bioeng. Symp. 11 (New York: John Wiley \& Sons, 1981) ${ }^{\dagger}$ 
774 R. K. Genung et al., A Summary of the Oak Ridge ANFLOW Pilot Plant Project, ORNL/TM-7582 (July 1981) ${ }^{\dagger}$

775 C. D. Scott and R. K. Genung, "Fixed-Bed, Anaerobic Treatment of Wastewater for Energy Conservation and Methane Production," Proceedings of the 16th Intersociety Energy Conversion Engineering Conference 1, pp. 583-85 (New York: American Society of Mechanical Engineers, 1981) ${ }^{\dagger}$

776 D. C. M. Hines, Production of Ammonia in a Packed-Bed, Anaerobic Upflow (ANFLOW) Bioreactor, ORNL/TM-7622 (August 1981) ${ }^{\dagger}$

777 R. K. Genung, D. C. Hines and D. W. Weeter, "Production of Ammonia in a Packedbed Anaerobic Upflow (ANFLOW) Bioreactor," Am. Inst. Chem. Eng. 77, pp. 286$94(1981)^{\dagger}$

778 C. D. Scott, ed., "Proceedings of the Fourth Symposium on Biotechnology in Energy Production and Conservation," Biotech. Bioeng. Symp. 12 (New York: John Wiley \& Sons, 1982)

779 E. Greenbaum, "Application of Intact Algae to the Biophotolysis Problem," Biotech. Bioeng. Symp. 12, pp. 469-74 (New York: John Wiley \& Sons, 1982) ${ }^{\dagger}$

780 E. Greenbaum, "Photosynthetic Hydrogen and Oxygen Production: Kinetic Studies," Science 215, pp. 291-93 (1982) ${ }^{\dagger}$

781 E. Greenbaum, "Biosolar Hydrogen and Oxygen Production," Hydrogen Energy Progress IV, pp. 763-69 (1982) ${ }^{\dagger}$

782 T. L. Donaldson and O. L. Culberson, "Potential for Chemicals from Biomass," Energy from Biomass and Wastes VI, pp. 1205-25 (Chicago: Institute of Gas Technology, 1982) ${ }^{\dagger}$

783 O. L. Culberson and T. L. Donaldson, "Chemicals from Biomass: A Systems Analysis," Biotech. Bioeng. Symp. 12, pp. 291-96 (New York: John Wiley \& Sons, 1982) ${ }^{\dagger}$

784 A. L. Rivera, Heavy-Metal Toxicity Phenomena in Laboratory-Scale ANFLOW Bioreactors, ORNL/TM-7837 (April 1982) ${ }^{\dagger}$

785 R. K. Genung et al., "Energy Conservation and Methane Production in Municipal Wastewater Treatment Using Fixed-Film Anaerobic Bioreactors," Biotech. Bioeng. Symp. 12, pp. 365-80 (New York: John Wiley \& Sons, 1982) ${ }^{\dagger}$

786 D. J. Halbert and R. J. Wojtowicz, The Modeling of an ANFLOW Municipal WasteTreatment Unit, ORNL/MIT-342 (June 1982) ${ }^{\dagger}$

787 C. D. Scott, "Fermentation in a Fluidized-Bed Reactor," Chemtech 13(6), pp. 364-65 $(1983)^{\dagger}$

788 E. Greenbaum, R. R. L. Guillard and W. G. Sunda, "Biological Solar Energy Production with Marine Algae," BioScience 33, pp. 354-588 (1983) ${ }^{\dagger}$ 
789 E. Greenbaum, R. R. L. Guillard and W. G. Sunda, "Hydrogen and Oxygen Photoproduction by Marine Algae," Photochem. Photobiol. 37, pp. 649-55 (1983) ${ }^{\dagger}$

790 E. Greenbaum and J. Ramus, "Survey of Selected Seaweeds for the Simultaneous Photoproduction of Hydrogen and Oxygen," J. Phycol. 19, pp. 53-57 (1983) ${ }^{\dagger}$

791 J. Woodward and E. Greenbaum, "An Immobilized Chloroplast-Ferredoxin-Hydrogenase System for the Simultaneous Photoproduction of Hydrogen and Oxygen," Biotech. Bioeng. Symp. 13, pp. 271-76 (New York: John Wiley \& Sons, 1983) ${ }^{\dagger}$

792 R. K. Genung et al., "Pilot Scale Development of Fixed-Film, Anaerobic Bioreactors for Municipal Waste Water Treatment," Energy from Biomass and Wastes VII, pp. 647-70 (Chicago: Institute of Gas Technology, 1983) ${ }^{\dagger}$

793 T. L. Donaldson and O. L. Culberson, Chemicals from Biomass: An Assessment of the Potential for Production of Chemical Feedstocks from Renewable Resources, ORNL/TM-8432 (June 1983) ${ }^{\dagger}$

794 T. L. Donaldson and O. L. Culberson, "An Industry Model of Commodity Chemicals from Renewable Resources," Energy 9, pp. 693-707 (1984) ${ }^{\dagger}$

795 E. Greenbaum, "Biophotolysis of Water: The Light Saturation Curves," Photobiochem. Photobiophys. 8, pp. 323-32 (1984) ${ }^{\dagger}$

796 E. Greenbaum, "Photosynthetic Water Splitting," ORNL Review 4, pp. 14-19 (1984) ${ }^{\dagger}$

797 A. L. Rivera et al., The Loves Creek Anaerobic, Upflow (ANFLOW) Pilot Plant: Design and Start-Up, ORNL/TM-8828 (April 1984) ${ }^{\dagger}$

798 E. Greenbaum, "Platinized Chloroplasts: A Novel Photocatalytic Material," Science 230, pp. 1373-75 (1985) ${ }^{\dagger}$

799 E. Greenbaum, "Hydrogen and Oxygen Production by Photosynthetic Water Splitting," pp. 145-53 in Proceedings of the Second International Symposium on Hydrogen Produced from Renewable Energy, ed. O. G. Hancock and K. G. Sheinkopf (Chicago: Gas Research Institute, 1985) ${ }^{\dagger}$

800 M. E. Reeves and E. Greenbaum, "Long-Term Endurance and Selection Studies in Hydrogen and Oxygen Photoproduction by Chlamydomonas reinhardtii," Enzyme and Microb. Technol. 7, pp. 169-74 (1985) ${ }^{\dagger}$

801 H. B. Ward, M. E. Reeves and E. Greenbaum, "Stress-Selected Chlamydomonas reinhardtii for Photoproduction of Hydrogen," Biotech. Bioeng. Symp. 15, pp. 501-507 (New York: John Wiley \& Sons, 1985) ${ }^{\dagger}$

802 M. T. Harris et al., The Loves Creek Anaerobic, Upflow (ANFLOW) Pilot Plant Performance Summary, ORNL/TM-9317, EPA/600/2085/040 (March 1985)* 
803 E. Greenbaum and M. Reeves, "Photosynthetic Water Splitting: A Biotechnological Approach to Gaseous Fuel Synthesis," Proceedings of the 1986 International Gas Research Conference IV, pp. 49-54 (Chicago: Gas Research Institute, 1986)*

804 B. H. Davison and C. D. Scott, "Ethanol Production from an Industrial Feedstock by Immobilized Zymomonas mobilis in a Fluidized-Bed Bioreactor," Biotech. Bioeng. Symp. 17, pp. 629-32 (New York: John Wiley \& Sons, 1986)*

805 B. H. Davison and G. N. Stephanopoulos, "Stability and Coexistence due to Inhibition in a Continuous Mixed Culture,". Biotechnol. Bioeng. 28, pp. 1442-52 (1986)*

806 C. D. Scott, "Dispersed-Phase Adsorbents for Biotechnology Applications," Proceedings Second International Conference on Separation Technology, Schloss Elmau, Klais, Federal Republic of Germany, April 26-30, 1987*

807 C. D. Scott and D. K. Dougall, Plant Cell Tissue Culture-A Potential Source of Chemicals, ORNL/TM-10521 (August 1987)*

808 C. D. Scott, "Immobilized Cells: A Review of Recent Literature," Enzyme Microb. Technol. 9, pp. 66-73 (1987) ${ }^{\dagger}$ 


\section{SOLAR TECHNOLOGY}

809 R. T. Young, "Laser Techniques in Photovoltaic Application," Proc. First Republic of China Solar Cell Workshop, Taipei, Taiwan, June 5-6, 1980, p. 10 (Taipei: Industrial Technical Research Institute, 1980) ${ }^{\dagger}$

810 R. T. Young et al, "Electrical Characteristics of Ion-Implanted Laser-Annealed Silicon," Radiation Effects 47, pp. 42-44 (1980) ${ }^{\dagger}$

811 D. H. Lowndes and R. F. Wood, "Time-Resolved Reflectivity during Pulsed-Laser Irradiation of GaAs," Appl. Phys. Lett. 38(12), pp. 971-73 (June 15, 1981) ${ }^{\dagger}$

812 D. H. Lowndes et al., "Pulsed-Laser Annealing of Ion-Implanted Semiconducting GaAs for Homojunction Solar Cells," Proc. 15th IEEE Photovoltaic Specialists Conference, May 1981, pp. 45-51 (New York: Institute of Electric and Electronic Engineers, 1981) ${ }^{\dagger}$

813 R. T. Young et al., "Substrate Heating and Emitter Dopant Effects in Laser-Annealed Solar Cells," Appl. Phys. Lett. 39(4), p. 313-15 (1981) ${ }^{\dagger}$

814 B. J. Feldman (Univ. Missouri) and D. H. Lowndes, "Photoluminescence of Pulsed Laser Irradiated n- and p-GaAs," Appl. Phys. Lett. 40(1), pp. 59-61 (January 1, 1982) ${ }^{\dagger}$

815 D. H. Lowndes, "Time-Resolved Optical Transmission and Reflectivity of PulsedRuby Laser Irradiated Crystalline Silicon," The American Physical Society Review Letters 48(4) (January 25, 1982) ${ }^{\dagger}$

816 S. A. Carnes, M. Schweitzer, and B. H. Bronfman, Community Based Assessment and Planning of Energy Futures: Final Report of the Decentralized Solar Energy Technology Assessment Program, ORNL-5879 (August 1982) ${ }^{\dagger}$

817 R. T. Young et al., "Characterization of Excimer Laser Annealing of Ion Implanted Si," IEEE Electron. Device Letters EDL-3(10), pp. 280-83 (October 1982) ${ }^{\dagger}$

818 D. H. Lowndes et al., "Pulsed Excimer Laser Annealing of Ion Implanted Silicon: Characterization and Solar Cell Fabrication," Appl. Phys. Lett. 41(10) (November $15,1982)^{\dagger}$

819 D. H. Lowndes, G. E. Jellison, Jr. and R. F. Wood, "Time-Resolved Optical Studies of Silicon during Nanosecond Pulsed-Laser Irradiation," Phy. Rev. B 26(12), pp. 6747-55 (December 15, 1982) ${ }^{\dagger}$

820 S. I. Kaplan, Evaluation of Mississippi County Community College and Northwest Mississippi Junior College Solar Power Systems, ORNL/TM-8396 (December 1982) ${ }^{\dagger}$ 
821 D. H. Lowndes and B. J. Feldman, "Photoluminescence of Pulsed Ruby Laser Annealed Crystalline and Ion Implanted GaAs," Laser and Electron-Beam Interactions with Solids, pp. 689-94 (Elsevier Science Publishing Co., Inc., 1982) ${ }^{\dagger}$

822 R. T. Young and R. F. Wood, "Laser Processing of Semiconductor Materials," Ann. Rev. Mater. Sci. 12, pp. 323-50 (1982) $)^{\dagger}$

823 J. A. Mullens, Model of the Solar Power Supply System of the Mississippi County Community College, ORNL/TM-8262 (January 1983) ${ }^{\dagger}$

824 J. T. Meador, Assessment of Rankine Cycle Heat Engines for Small Solar Power Applications, ORNL/TM-7287 (November 1983) ${ }^{\dagger}$

825 S. I. Kaplan, Mississippi County Community College Solar Power Supply System: Final Summary Report, ORNL/TM-9859 (February 1986)*

826 S. I. Kaplan, Determination of Effects of Atmospheric Contamination on Photovoltaic Cells in Concentrating Systems, ORNL/TM-10201 (December 1986)* 


\section{GEOTHERMAL}

827 G. H. Llewellyn, Design and Analysis of a 5-MW Vertical-Fluted-Tube Condenser for Geothermal Applications, ORNL/TM-8100 (March 1982) ${ }^{\dagger}$

828 A. W. Reed et al., Evaluation of : NEPA-Based Environmental Commitments at Four Geopressure Design Wells, ORNL/TM-8657 (September 1983) ${ }^{\dagger}$

829 J. W. Webb, G. K. Eddlemon and A. W. Reed, Retrospective Examination of Geothermal Environmental Assessments, ORNL/TM-9071 (March 1984) ${ }^{\dagger}$ 


\section{CONTINUOUS CHROMATOGRAPHY IN MULTICOMPONENT SEPARATIONS}

830 C. H. Byers, "An ASPEN Simulation of Fuel Production by Hydrolysis of Woody Biomass," Journal of Applied Biochemistry and Biotechnology (January 1988)*

831 A. J. Howard (Univ. Fla.), G. Carta (Univ. Virginia) and C. H. Byers, Separation of Sugars by Continuous Annular Chromatography, ORNL/TM-10318 (August 1987)* 
(this page intentionally left blank) 


\section{AUTHOR INDEX}

Abbatiello, L. A. . . . 131, 132, $134,140,164$

Abi-Samra, N. C. . . . . 639

Achenbach, P. R. . . . . 257

Ackermann, R. A. . . . . 230

Adler, M. V. : . . . . . . 596

Aldrich, T. M. . . . . 650, 684

Alexander, G. H. . . . . 150

Allied Corp., Chemical

Sector ...... 201, 202

Ally, M. R. . . . 522, 523, $525,526,527$

Amirkhanian, K. R. . . . . 327

Andersen, P. F. . . . . . 686

Anderson, Robt. W. \& Assoc. $\quad .262$

Arcuri, E. J. . . . . . . 770

Arehart, J. T. . . . . . 15

Armstrong, J. . . . . . . 12

Arthur D. Little,

Inc. . . . 126, 127, 174, 209

Aseltine, M. . . . 104,322

Askins, H. W. Jr. . . . . 626

Auld, D. L. . . . . 746

Ayres, J. W. . . . . 5
Ayres, R. U. . . . . . 5

Bair, R. . ... . . . 472

Bair, S. . . . . . . . 590

Baker, Q. A. . . . . . 493

Baldoni, J. G. . . . . . 453

Bales, E. L. . . . . 272, 274, 312

Ball, S. J. . . . . . . . . 123

Ballou, M. L. . . . . 132, 140

Barnes, M. H. . . . . . . . 359

Barnes, P. R. . . . . . . . 626

Barnes, R. W. . . . 31, 37, 38, 39

Barron, W. . . . . 736

Battelle Columbus Laboratory . 173

Bauman, H. F. . . . . . . 356

Baxter, V. D. . 136, 142, 170, 191

Bayne, C. K. . . . . . . 362, 367

Becher, P. F. . . 405, 406, 414, 416, $422,425,427,428$, $432,433,443,445$, $450,451,452,454$, $455,456,458,572,581$

Bechtold, R. L. . . . 483, 496, 497

Beck, J. V........ 358

Becker, J. M. . . . . . 260 
Beecher, D. T. . . . . . 227

Brinker, M. J. . . . . . . 350

Bell, D. J. . . . . . . . 619

Brinkman, C. R. . . . 424, 446

Berlad, A. L. . . . . . . 263

Broders, M. A. . . . . . . . 344

Berry, L. G. . . . . 19, 27, 45, 52, $61,91,108,363$, $580,383,390,391$

Besmann, T. M. . . . . 567

Biggs, R. B. . . . . . 627

Bircher, T. L. . . . . . 386

Birdwell, J. D. . . . . . . 630

Bjornstad, D. J.. . . . . . . 733

Blanchard, J. P.. . . . . . . 678

Blankenhorn, P. R. . . . . 751

Bledsoe, J. L. . . . . . . . 145

Blue, J. L. . . . . . . 7, 15, 22

Boardman, R. W. . . . . 605

Bode, K.-H. . . . . . . . 269

Boercker, F. D. . . . 368, 378, 594

Boggs, D. . . . . . . . 213

Bond, W. D. . . . . . . . 462

Borkowski, R. J. . . . . 345, 698

Bradt, R. C. . . . . 427, 428, 431

Braid, R. B. . . . . . . 51

Braithwait, S. D. . . . . . 663

Braunstein, J. . 524, 696, 700, 711

Brice, C. W., III . . . . 664

Brog, T. K. . . . . . 421

Bronfman, B. H. . . . 56, 65, 816

Bronfman, L. M. . . . 32, 47, 54, $597,598,599$

Brown, M. A. . . . . 81, 82, $99,101,107$, $113,117,119$ $293,299,389,601$

Brown, S. R. . . . . . . . 717

Buckels, L. S. . . . . . . . 106

Buljan, S. T. . . . . 4 453, 454

Burghard, H. C. Jr. . . . . . 477

Burke, J. C. . . . . . . . 208

Burnett, M. . . . . . . . 193

Burrage, L. M. . . . . . . . 671

Busching, H. W. . 278, 291, 305, 327

Buzza, T. G. . . . . . . . 489

Byers, C. H. . . . . . $\quad 830,831$

Campen, G. L. . . . . . . . 610

Cantor, S. . . . . . . . . 696

Caponetti, E. . . . . . 507

Carbajo, J. J.. . . . . . 716

Cardell, N. S. $\quad . \quad . \quad \ldots \quad 40$

Carduner, K. R. . . . . . 441 
Carignan, F. J. . . . . 585

Carlisle, N. . . . . . 372

Carlsmith, R. S. . . . . 33

Carnes, S. A. . . . . . . 816

Carney, J. . . . . . . 23

Carpenter, J. A., Jr.. . . 560, 565,573

Carroll, W. L. . . . . 323, 324

Carta, G.

Chang, T. . . . . . 278

Charles River Associates . . . 34

Chen, C. F. . . . . . . 440

Chen, C. K. . . . . . . 46

Chen, F. C. . . . . 180, 226

Chen, J. . . . . . . . 704

Chen, N. C. J. . . . . 187, 215

Chester, C. V. . . . . . 276

Chiappetta, S. . . . . 310

Childs, K. W. . . . . 234, 240, 274, 302, 306

Christian, J. E. . . . . 267, 284, $303,321,333$

Christophorou, L. G. . . 668, 681,682

Chuang, T. J. . . . . 440

Cochran, J. K. . . . . . 569

Cohn, S. M. . . . . . 18, 40

Collins, N. E. . . 49, 51, 73, 595
Compere, A. L. . . . . 499, 500, 501,502 , 503, 504, 505, 506

Consolidated Natural Gas

Service Company . . . . . 124

Consumer Energy Council of Amer. Research Foundation . . 105

Cooke, C. M. . . . . . . . 662

Copenhaver, E. D. . . . . 307

Corum, K. R. . . . . . . 21

Courville, G. E. . . . 251, 272, 274, 283, $294,295,305,326$

Cowles, J. R. . . . . . . 761

Cox, R. L. . . . . . . . 520

Creswick, F. A.. . . . . . 123

Crosbie, G. M. . . . . . . 429

Culberson, O.L.." 782, 783, 793, 794

Curlee, T. R. . . 556, 564, 571, 577

Curtice, D. H. . . . $605,625,657$

Cushman, J. H. . . . . 726, 727, 728,731 , $734,742,752,756$

Das Gupta, A. . . . . . 563

David, S. A. . . . . 412

Davidson, W. F. . . . 518

Davis, W. T. . . . . 336

Davison, B. H. . . . 804,805

Davison, J. E. . . . . . 687

Deanin, R. D. . . . . . 557 
Denny, J. C. . . . . 485, 491

Desjarlais, A. O. . . . . 249

Dethlefsen, R. . . . . . . . 648

DeVan, J. H. . . . . . . . . 583

DeVore, C. E. . . . . 592

Dewey, B. R.. . . . . . . 609

DeWitt, D. P.. . 128, 148, 158, 163

Dickey, D. W. . . . . . 495

Didion, D. A. . . . 217, 220

Dinan, T. M. . . . . 100, 116

Dỉstefano, J. R. . . . . . . 583

Domanski, P. A. . . . . . 220

Domingo, N. . . . . 180, 194, 365

Domingorena, A. A.. . . . . 123

Donaldson, T.L.. 782, 783, 793, 794

Dougall, D. K. . . . . . . . 807

Dougall, R. S. . . . . . . 206

Dudney, C. S. . . . . 246, 260

Dufrane, K. F. . . . 438, 442, 449

Dugan, R. C. . . . . $620,621,637$

Dybeck, R. . . . . . . .606

Easterly, C. E. . . . 612, 650, 684

Eberhardt, J. J. . . . . . . 565

Echenique, P. M. . . . . 666, 667

Ecklund, E. E. . . . . . . 479

Eddlemon, G. K. . . . . . 829
Edmonds, J. A. . . . . 37, 38, 39

Ehrenshaft, A. R. . . . . 366

Eissenberg, D. M. . 685, 688, 689

Eksel, M. . . . . . . . 347

El-Antably, A. M. . . . . 636

Elmore, J. L. . . . . . . . . 742

Energy, Department of. . . 141, $341,342,531$

Energy Utilization Systems,

Inc. . . . 137, 144, 166, 607

Engheta, N. . . . . . . 643

Englesson, G. A. . $\quad 338,339,348$

Erickson, D. C. . . . . . 518

Erwin, J. . . . . . 475, 490

Fagan, T. J. . . . . 175, 218, 227

Federer, J. I. . . . . . . . . 528, $529,530,532$, $533,534,540$, $543,547,548$, $549,550,551,554$

Feldman, B. J. . . . . $\quad 814,821$

Ferber, M. K. . . . . 4 435, 451

Fick, G. W. . . . . . . . . 748

Fillatti, J. J. . . . . . . . 744

Fine, H. A. . . . . . 238, 578

Fiorato, A. E. . . . . . . 265

Fischer, R. D. . . . . . 172, 177

Fischer, S. K. . . . . 155, 188

Fitzgerald, K. F. . . . . . . 208 
Flores, F. . . . . . . 666

Folger, A. G....... . 755

Fontana, E. C. . . . 370, 703

Foster, D. E. . . 476, 481, 486

Fox, A. . . . . . . 11

Frantzis, L. . . . . . 208

Frogge, L. M. . . . . . 366, 368

Frysinger, G. R. . . . . . . 695

Fulkerson, W. . . . . . . 33

Fuller, E. R., Jr. . . . . . . . 434

Fuller, L. C. . . . . . . . 583

Gant, R. E. . . . . . 337, 343

Garzon, R.. . . . . . . 623

Gatton, D. W. . . . . . 350

Geist, G. A. . . . . 712, 713

General Electric Co. . . . . 192

Genung, R. K. . . . 762, 765, 774, $775,777,785,792$

Gerstmann, J. $\ldots \ldots \ldots$

Giles, G. E. . . . . 254

Gillette, G. . . 101, 113, 287, 290

Glaeser, W. A. ..... 442, 449

Glavincevski, B. ..... 490

Glicksman, L. R. . . . 310, 317

Gnadt, P. A. . . . . . . 640
Göeltz, R. T. . . . . 26, 35, $58,60,62$, $66,71,85$, 93, 94, 96, $98,109,112,384$

Goldenberg, D. . . . . $\quad 393$

Googin, J. M. . . . . 499, 501, 503, 505, 506

Grad, M. L. . . . . . 597, 598

Grady, S. . . . . . . . 29

Graves, R. L. . . . . 468, 469, $480,482,487$

Graves, R. S. . . . $\quad 308,328$

Graviano, A........ 236

Greenbaum, E. . . . . . 763, 767, 768, 769, 771, 772, 779, $780,781,788$, $789,790,791$, $795,796,798$, $799,800,801,803$

Greene, D. L. . . . 6, 30, 43, 46, $57,67,69,95,469$

Greenwald, F. T. . . . . . 641

Gregory, E. W. . . . . . . 469

Griess, J. C. . . . . . . . 197

Griffin, F. P. . . . . 187, 215

Griffin, G. . . . . . . 682

Griffioen, J. A.. . . . . 590

Griffith, W. L. . . . 499, 500, 501, $502,503,504,505,506$

Grossman, G. ․ 210, 509, 510, $511,512,513,516$ 
Guillard, R. R. L. . . $\quad$ 788, 789

Gunther, E. W. . . . . . . 677

Gustinis, J. . . . . . . 281

Gutraj, J. M. . . . . . . 222

Hahn, J. M. . . . . . . . . . 672

Halbert, D. J. . . . . . 786

Hamilton, R. M. . . . . . . 672

Hammond, J. P. . . . . . . 412

Hancher, C. W. . . . . 770

Hanchey, C. M. . . . . . 86

Hankins, K. E. . . . . . . 473

Hansen, E. A. . . . . . . 760

Harris, L. A. . . . . . . 545

Harris, M. T. . . . . . . . 802

Harris, W. W. . . . . . . 255

Hasselman, D. P. H. . . . . 417

Hay, P. H. . . . . . . . 565

Heath, M. T. . . . . . . . 512

Heatherly, D. E. . . . . . 700

Heilman, P. E. . . . . . . 745

Henson, T. J. . . . . . . . 582

Hettiarachchi, S. . . . . . 521

Heyne, C. J. . . . . . . . . 636

Hilliard, M. . . . . . . 89

Hillis, S. L. . . . . . . 484, 494

Hines, D. C. M. - . - 776, 777
Hinkle, N. E. . . . . . . 260

Hirst, E. A. . . . . 1, 2, 8, 9, $12,13,14,16,22$, $23,24,25,26,27$, $28,29,33,35,36$, $48,50,52,55,58$, $59,60,62,64,66$, $71,76,77,79,80$, $83,85,88,92,93$, $94,96,98,109,111$. $114,120,121,122,384$

Hittman Assoc. . . . . 360, 361

Hodgson, J. W. . . . 75, 485, 491

Hoffman, H. W. . . . 685,694

Holcomb, M. C. . $\quad 42,63,70,86,87$

Holman, A. S. . . . . . . 131

Holub, E. . . . . 64, 72, 76, 89

Honeywell, Inc. . . . 133, 186

Honkala, V. A. . . . . . 596

Hooker, J. N. . . . . . 17, 75

Horn, G. . . . . . . . . . 519

Horton, J. A. . . . . . . . . . 563

Houska, C. R. . . . . . . 591

Howard, A. J. . . . . . 831

Hsu, S. M. . . . . . . 587

Hu, P. S. . . . . 55, 67, 70, $78,90,103,106$

Hubbard, M. . . . . . . 390

Huckabee, M. L. . . . . . 453

Huntley, W. R. . . . . . . 185

Isaksen, L. . . . . . . . . . 603 
Isaksen, T. . . . . . 239

Jackson, W. L. . . . . 180

James, D. R. . . . . . 624

Janney, M. A. 426, 445,546, 552, 553

Janssen, J. E.• $\ldots \ldots 296$

Jaszewski, G. M. … _ . 642

Jellison, G. E. Jr. • — 819

Jenkins, M. G. . . . . 447, 448

Jewell, W. T. . . . . 614, 627, 634

John Weidt Assoc., Inc. . . . 231

Johnson, D. R. . . . . . . . 266, $364,367,408,409$, $415,419,420,437$, $439,444,459,463,464$

Johnson, J. S. $\cdots \cdots \quad$ 507, 710

Johnson, L. A. . . . . 622

Johnson, W. S. . . 4, 104, 178, $183,203,221$

Johnson-Mohler, E. . . 104, 322

Johnston, J. W. . . . . 752, 756

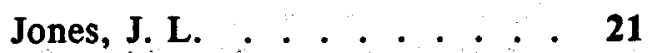

Jones, P. D. . . . . . . 356

Jones, P. J. . . . . . . . 550

Jordan, A. . . . . . . . 573

Julien, J. T. . . . . . . . 265

Jung, L. . . . . . . . . . 394

Juul, H. . . . . . . . 239

Kahl, w. K. . . . . . . 480
Kamp, G. A. . . . . . 372

Kaplan, S. I. . . 515, 820, 825, 826

Karnitz, M. A. . . . . 340, 345, $346,349,354$ $355,358,374$, $396,397,399,400$

Katz, W.........656

Keating, H. . . . 4 436, 570

Keating, K. . . . . . $\quad \ldots 83$

Kedl, R. J.. . . 386, 387, 395, 691

Kennedy, C. R.. . . . . 545

Kenneth Labs _ . . . . . . 253

Keshock, E. G. . . . . 365

Kim, C. . . . . 476, 481

Kinser, D. L.. . . . . . . 647

Kleinfelder, W. A. . . . 280

Klemens, P. G. . . . . . 304

Knight, P. . . . . . . 23

Knutsen, C. . . . . . . . 121

Kolb, J. O. 283, 336, 351, $352,353,354,356$

Konoike, T. . . . . . . . 568

Koshy, S. . . . . . . . 63

Krautbauer, M........ 353

Kreitler, V. . . ....97

Krepchin, I. P... . . . . 193

Kroeger, D. M. . . . . . 680

Krummel, J. R. . . . . . 758 
Kuliasha, M. A. . . 179, 385, 603,$604 ; 615$

Kulp, G. . . . . 3, 10, 41, 42

Kurzius, S. C. $\quad \ldots . . . . . . .31$

Lackey, W. J. . . . . . . 410

LaCosse, R. A. . . . . . . 266

Land, S. B. Jr. . . . . . . 732

Lander, M. L. . . . . . . . 461

Larson, S. C. . 300, 314, 315, 325

Lauf, R. J.. . . 404, 539, 618, 641

Launay, P. F. . . . . . . . 149

Lawrence, W. T. . . . . . . 143

Lawton, E. A. . . . . . . . 167

Layton, P. A. . . . . . . . 759

Lazare, P. . . . . . . . . 8

Lee, E. H. . . . . . . . . 582

Lee, K. P. . . . . . . . . 195

Lefebvre, A. H. . . . 474, 487

Legro, J. R. . . 639, 644, 645, 659

Leitnaker, J. M. . . . . . . 592

Lerman, D. I. . . . . . 56, 65

Levins, W. P. . . . . 1 129, 146, $157,397,399,400$

Levinson, L. M. ․ . . 628, 656

Levinson, T. M. . . . . . 587

Litzinger, T. A. . . . . . 489

Liu, C. T. . . . . . 558, 559, $563,566,582$
Liu, K. C. . . . . 424, 446

Llewellyn, G. H. . . 537, 542, 827

Long, E. L., Jr.. • . . • . 480

Long, H. M. . . . 602, 610,620

Long, K. P. . . . . . . 243

Longmire, C. L. . . * * 672

Lowndes, D. H. . • . 811, 812, 814, $815,818,819,821$

Lyle, F. F. Jr. . . . . . . . 477

Ma, F. S. . . . . . . 603

MacCarthy, P. W. . . 152, 153, 154

MacDonald, J. M. 393, 394, 398, 402

Macriss, R. A. . . . . 211, 222

Mahan, G. D. . . . . . . 628

Mahler, K. A. . . . . .. . 746

Maier, R. . . . . . . . 16

Mann, L. K. . . . . . 730, 737

Manning, H. . . . . . . . . 35

Marans, R. W. . . . . . . 119

Martin, J. F. . . . 690, 694, 697, $699,707,709$, $715,722,723,724$

Martin, P. C. . . . . . 316

McBrayer, J. F. . . . . . . 729

McCarthy, C. I.. . . . . . 184

McClintock, F. A. . . . . . 629

McClung, R. W. . . . . 576

McCold, L. N. . . . 49, 355, 379 
McConnell, B. W. . . . . 678

McCoy, H. E..Jr. . . . 638

McElroy, D. L. . . . 255, 285, 328

McGill, R. N.. . . . $\quad 75,87$, $468,470,479$, $482,484,491,494$

McGranaghan, M. F. . . 677 McGraw-Edison Power

Systems . . 620, 621, 660, 671, 679

McHargue, C. J. . . . 588, 589

McLain, H. A. . . . 330, 350, 373, $374,381,392,393$

McLaughlin, R. A. . . . . 760

Meador, J. T. . . . . . . . 824

Mechanical Technology,

Inc. . . . . 130, 168, 198, 230

Mei, V. C. . . $181,188,219,229$

Melton, B. S. . . . . 334

Menendez, L. F. . . . 53, 368, 371

Mertol, A. . . . . 323, 324

Michelson, E. . . . 210, 516

Middleton, M. G. . . . 171, 182

Miller, D. R. . . . . . . 145

Miller, W. A. . . . . 165, 228

Minturn, R. E. . . . . . 135

Mixon, W. R. . . . . . . 395

Modine, F. A. . . . 655,683

Molz, F. J. . . . . . . . . 686
Moorhead, A. J. . . . 4 404, $411,436,549$, $570,572,580,581$

Morel, T. . . . . . . 466

Morgan, C. S. . . . . . $\quad . \quad 539$

Morris, L. E. . 366, 369, 560, 573

Morris, M. D. . . . . . . . 684

Moyers, J. C.. . . . . . . . 191

Mrochek, J. E. . . . . . . 764

Mroz, G. D. . . . . . . 754

Mueller Assoc., Inc. . . . . 498

Mullens, J. A. . . . . . . 823

Mulroney, P. . . . . . . . 334

Mulroy, W. . . . . . . 217

National Bureau of

Standards . . . 125, 139, 217, 220

National Water Well Assoc..... 138

Nelson, B. D. . . . . . 319

Nelson, R. . . . . . 704

Nelson, R. T. . . . 152, 153, 154

Nephew, E. A. . . 132, 140, 164

Nguyen, H. . . . . . 617

Nguyen, H. D. . . . . . 11

Nichols, C. L. . . . 244

Nicol, J.L.... . . . . . . 388

Nixon, R. J. . . . . . 456

Nyman, H. O. . . . . . 353 
O'Neal, D. L. . . . . . 21

O'Neal, G. B. . . . . . . . 493

Olsen, K. O. . . . . 364

Olszewski, M. . . . 370, 373, 701, 703, 706

Ong, E. T. . . . . . . 722

Oregon Dept. of Energy . . . 233

Ostrogorsky, A. G. . . $\quad 310,317$

Overholt, P. N. . . . . . . 602

Pan, L. . . . . . 200,514

Pan, Y. M. . . . . . . . 430

Park, J. E. . . . . . . 254, 309

Parr, A. D. . . . . . . 686

Parrish, D. J. . . . . . 747

Pasto, A. E. . . . . . 538

Patel, K.. . . . . . . 372

Patterson, M. R. . . 214, 517, 524

Patton, M. . . . . . . 16

Patton, R. . . . . . . . 605

Paulsen, E. . . . . . . 239

Pavlenco, G. F. . . . . 339

Peach, H. G. . . . . . . 114

Pearman, N. . . . . . . 331

Peart, M. V. . . . 128, 148, 163

Penoncello, S. G. . . . . . 156

Perez-Blanco, H. . . 200, 214, 508, $509,514,517,524$
Perry, A. M. . . . . . 216

Petri, R. J. . . . . . . . 722

Pflanz, H. M. . . . . . 674

Philipp, H. R. . . . . 628

Pierce, F. E. . . . . . . . 4

Pitt, W. W. . . . . 762, 764

Plastics Institute of

America .... . 574, 575

Polinski, F. . . . . . . 704

Poore, W. P. . . . . . 179

Pope, P. E.. . . . . . . . . 760

Porcher, Jr., J. P. . . . . . . . 291

Princeton University . . . . 235

Prowler, D. . . . 104, 322

Pruchnic, S. J., Jr. . . . . . 465

Purucker, S. L. . . . . . . 112, $117,651,661$

Quinby, T. C. . . . . . 647

Quinn, T. F. J. . . . . . . 593

Rajan, S. . . . . . . . 478

Ramrus, A. . . . . . . 658

Ramus, J. . . . . . . . . . 790

Ranney, J. W. . . 726, 727, 728, $731,738,740$, $750,753,757,759$

Rao, K. V.. . . . . . . 748

Rao, S. . . . . . . . 591

Rasmussen, R. W.. . . . . . 296 
Reed, A. W. . . . . 8 828, 829

Reed, J.H. . . . . 51, 646

Reeves, G. . : :

Reeves, M. E. . . . 800, 801,803

Reister, D. B. . . . . 37, 38, 39

Rice, C. K. . . . . 151, 155, 225

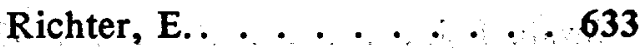

Ridge, C. R. • • •

Rink, K. K. •. . . . . 474,487

Riordan, J. M.

Ritchie, R. H. • • 666,667

Rivera, A. L. • . • . 784, 797

Rizy, D. T. • • • • 608, 613, $631,634,637,677$

Roberts, G. F. . . . . . . 57

Robertson, D. K. . . . 281, 286

Robinson, J. N. . . . 244, 250

Rockenfeller, U. $\quad 519,718,720,723$

Rockwood, D. L. . . . . . . 735

Rodriguez, A. . . . . 652

Rorke, M. G. . . . 47,54

Rorke, M. L. . . . . 599

Rosenfield, A. R. . . . 449

Ruccia, F. E.. . . . . . . 143

Ryan, T. W., III . . . . 488

Sakai, M. . . . . . . . . 431

Salk, M. S. . . . . . . . . 755
Salyer, I. O. . . . $\quad \ldots 87$

Samuels, G. . . . . . . . 20

Santella, M. L. • . . • 423, 562

Sauber, R. S. . . . . 171, 182

Sauers, I. . . . $\quad 635,654,665$, $668,669,670,681$

Scanlan, T. F. . . . . . 367

Scarpellino, C. D. . . . . 277

Schaffhauser, A. C. . . . 407

Scheid, H. W. . . . . . . 761

Scheitlin, G. G.. . . . . 158

Schienle, J. . . . . . . . 460

Schioler, L. J. . . . . . . 418

Schott, J. . . . . . 261, 264

Schulz, R. B. . . . . . . 444

Schutt, J. R. . . . . . . 750

Schutte, W. C. . . 241, 242, 243

Schweitzer, M. . . . . . . 816

Scott, C. D. . . 766, 770, 773, $775,778,787$, $804,806,807,808$

Scott, P. V. . . . . . 467

Scull, N. . . . . 476, 481

Sefer, N. R. . . . 475, 490

Shapira, H. B. . . . . . 273

Sharp, T. R. . . . . 402

Sheppard, K. . . . . 236, 282

Shirley, S. T. . . . . . . . 329 
Shugart, H. H. . . . $\quad \ldots 750$

Sikka, V. K. . . . 566, 579

Silvers, J. P. . . . . . 297, 298

Simpson, T. L. . . . . . 664

Simpson, W. A., Jr. . . . . 576

Smith, I. D. . . . . . . . . 649

Smyth, J. . . . . . 460

Snow, F.. . . . . . . 252

Soderstrom, E. J. . . . . . . 27, $47,54,597$, $598,599,600$

Solomon, A. D. . . . . 693, 719

Somerville, M. H. . . . . . . . 156

Sonder, E. . . . . . 647,656

Sorensen, J. H. . . . . . . . 595

Southworth, F. . . . . . . . 74

Spyrou, S. M. . . . . . . 668

Steele, R. S. . . . . . . . . 701

Stephanopoulos, G. N. . . . . 805

Sterling, R. . . . . . 289, 320

Stern, P. C. . . . . . . . . 110

Stettler, R. F. . . . . . 745

Stiel, L. I. . . . . . . . 725

Stoecker, W. F. . . . 159, 184, 213

Stoloff, N. S. . . . . . . 558

Stovall, J. P. . . . . . . 634, 673
Stovall, T. K. ․ . . 118, 345, $362,374,375$, $376,385,387,388$

Strickford, Jr., G. H. . . . 177

Sullivan, R. . . . $\quad 323,324$

Sunda, W. G. . . . $\quad 788,789$

Sundberg, R. E. . . . $\quad \ldots \quad 335$

Swab, J. J. . . . . . . 455

Swain, M. N. . . . . . 467

Swain, M. R. . . - 4 467, 492

Syed, R. . . . . . . . . 417

Tectonics Research, Inc. . . . 186

Teichman, K. $\quad . \quad \ldots \quad \ldots 352$

Tennery, V. J. . . . 403, 413, 528, $529,530,532$, $533,534,535,536$

Ternes, M. P. . 4 401, 692, 714

Tesche, F. M. . . . . . 639, 678

Tetreault, R. D. . . . . . 169

Tevepaugh, J. A. . . . . . . 394

Thacker, W. . . . . . . 721

Thomas, B. . . . . . . . 11

Thomson, E. M. . . . . . . 653

Tiegs, T. N. . . . . 404, 406, 414, $422,425,432,433$, $443,445,450,452,458$

Tien, T. Y. . . . . . . . 417

Till, L. E. . . . . . . . 67, 103 
TLH Associates, Inc. . . . 256

Tong, T. W. . . . . 301, 313

Tonn, B. E. . . . 5 56, 61, 64, $76,89,102,112$, $115,377,380,383$

Toor, I. A. . . . . . 237, 248

Toscano, W. M. . 147, 169, 195

Treado, S. . . . . 287, 290

Trimble, J.. . . . . . . . 26

Trimble, J. L. . . . . . . . 731

Triolo, R. . . . . 502, 504, 507

Troyer, R. . . . . . 311

Trumble, D. . . . 93, 109

TRW .......... 161

Tsao, H. J. . . . . . 41, 52

Turhollow, A. F. . 742, 752,756

Turner, R. H. . . . . . . 226

Tye, R. P. . . 232, 249, 298, 332

United Engineers and

Constructors, Inc. . . . . . 360

Urquidi-Macdonald, M. . . . 521

Vallet, C. E. . . . 696, 700, 702

Van Brunt, R. J. . . . . . . 669

Van Geem, M. G. . . 265, 270, $271,288,300$, $314,315,325,329$

Van Liere, K. D. . . . . . . 611

Vasilakis, A. D. ․ . 130,168

Verschoor, J. D. . . . . . 316
Veyo, S. E. . . . . 175, 176

Vineyard, E. A. . . . . . 190

Vineyard, T. A. $\quad 68,84,382,391$

Vinyard, S. . . . . . . . 471

Wahiduzzaman, S. . . . . 466

Wakenell, J. F. . . . . . . . 493

Walker, D. H. . . . . . 169, 193

Walldorf, S. P. . . . . 640, 675

Walsh, P. J. . . . . . . 246

Walukas, D. J. . . . . . 294, 295

Wan, C. A.. . . . . . . 125

Wang, Y. . . . . . . . 616

Wantland, J. L. . . . . . 484, 494

Ward, H. B. . . . . . . . 801

Webb, J. W. . . . . . 829

Webber, R. E. . . . . . . . 41

Weeter, D. W. . . . . . . 777

Wei, G. C. . . . . 405, 416, $536,537,541$, $542,544,545,555$

Weil, R. . . . . . 236, 282

Wendt, R. L. . . . . 254, 258, 259

West, C. D. . . . . . . . 187

West, D. C. . . . . . 730, 737

Westinghouse Electric

Corp. . . . . . . 160, 218

Westmoreland, C. G. . . . 710

Wheeler, R. B. . . . . . 683 
White, C. L. . . . . . . 544

White, D. L. . . . 58, 60, 66, $71,79,102$, $107,115,117,390$

Whiting, D. . . . . . 279

Whittemore, O. J. . . . . 708

Wiederhorn, S. M. ․ . 434, 440

Wilbanks, T. J. . . . . . . . 33

Wildin, M. W. . . . . . 705

Wilkinson, E.. . . . 261, 264

Williams, R. K. . . . . 457, 641

Williams, R. O. . . . 537, 538, 561

Winer, W. O. . . . . 590, 593

Wojtowicz, R. J. . . . . . 786

Wood, R. F. . . . . 811, 819, 822

Woodhouse, J. J. . . . . . . 412

Woodward, J. . . . . . . 791

Wright, J. H. . . . . . . 245, 247
Wright, L. L. . • 739, 741, 743, 759

Wyman, C. . . . . . 688

Yarbrough, D. W. . . . 212, $237,245,247$, $248,255,275$, $285,308,318,328$

Yniguez, A. R. . . . . . 557

Young, R. T. . . . . 809, 810, $813,817,822$

Younkins, T. D. . . . . . 676

Yust, C. S. . . . . . $\quad 584,585$, $586,587,592$

Zaininger, H. W. . . 619, 632, 642

Zawacki, T. S. . . . 211, 222

Zehr, F. J. . . . . . . . 44, 199

Zilberstein, G. . . . . . . 454

Zimmerman, K. H. . . . . 189, 204, 205, $207,223,224$

Zuschneid, P. . . . . . 49 


\section{INTERNAL DISTRIBUTION}
1. E. D. Aebischer
2. M. R. Ally
3. V. D. Baxter
4. R. L. Beatty
5. J. J. Blass
6. P. J. Blau
7. H. I. Bowers
8. R. A. Bradley
9. H. R. Brashear
10. M. A. Broders
11. M. A. Brown
12. V. R. Bullington
13. R. S. Carlsmith
14. C.-H. Chang
15. J. E. Christian
16. A. L. Compere
17. W. L. Cooper
18. J. M. Corum
19. D. F. Craig
20. F. A. Creswick
21. T. R. Curlee
22. S. J. Dale
23. J. G. Delene
24. R. C. DeVault
25. A. L. Freeman
26. W. Fulkerson
27. U. Gat
28. R. L. Graves
29. R. S. Graves
30. D. L. Greene
31. J. H. Greene
32. F. M. Haggag
33. G. Harrison
34. F. C. Hartman
35. W. R. Hendrich
36. E. A. Hirst
37. R. C. Hudson
38. H. L. Hwang
39. D. R. Johnson
40. L. Jung
41. M. A. Karnitz
42. R. J. Kedl
43. J. O. Kolb

44. T. G. Kollie

45. E. H. Kreig

46. M. A. Kuliasha

47. E. L. Long

48. T. S. Lundy

49. J. M. MacDonald

50. M. F. Marchbanks

51. L. N. McCold

52. R. N. McGill

53. H. A. McLain

54. V. C. Mei

55-59. W. R. Mixon

60. A. J. Moorhead

61. R. K. Nanstad

62. H. Perez-Blanco

63. C. H. Petrich

64. S. L. Purucker

65. J. W. Ranney

66. C. K. Rice

67. D. T. Rizy

68. G. C. Robinson

69-73. A. C. Schaff hauser

74. M. A. Schmidt

75. M. Schweitzer

76. C. D. Scott

77. R. L. Senn

78. T. R. Sharp

79. R. B. Shelton

80. M. Siman-Tov

81. W. B. Snyder

82. G. G. Stevenson

83. E. J. Szarleta

84. V. J. Tennery

85. P. T. Thornton

86. R. I. Van Hook

87. K. E. Wilkes

88. D. F. Wilson

89. S. G. Winslow

90. S. B. Wright

91. K. H. Zimmerman

92-93. Laboratory Records

94. Laboratory Records--RC

95. ORNL Patent Office 


\section{EXTERNAL DISTRIBUTION}

96. D. Stanton-Hoyle, American Consulting Engineers Council Research and Management Foundation, 1015 15th Street, N. W., Washington DC 20005

97. L. J. Nilsson, Energy Systems Analysis, University of Lund, Gerdagatan 13, S-223 62 Lund, Sweden

98. B. Kavanaugh, Center for Energy Studies, Louisiana State University, Baton Rouge LA 70803-0301

99. H. Amistadi, Energy Engineer, Post Office Box 4904 DTS, Portland ME 04112

100. S. Thompson, Library, Solar Energy Research Institute, 1617 Cole Boulevard, Golden CO 80401

101. T. H. Kuehn, Associate Professor, Mechanical Engineering Department, University of Minnesota, 111 Church Street, S. E., Minneapolis MN 55455

102. K. Olsen, Energy and Environmental Analysis, 1655 North Fort Meyer Drive, Arlington VA 22209

103. W. F. Simpson, Jr., TIC, DOE/OSTI, Building 1916-T1, Room 32

104. B. G. Newman, ORAU, MERT Division, Library

105. J. P. Millhone, Director, Office of Buildings and Community Systems, CE13, Forrestal Building, Department of Energy, 1000 Independence Avenue, S. W., Washington DC 20585

106. J. A. Lenhard, Assistant Manager, Energy Research and Development, DOE/ORO, P. O. Box E, Oak Ridge TN 37831

107. G. C. Manthey, DOE/ORO, P. O. Box E, Oak Ridge TN 37831

108. L. H. McLaren, DOE/ORO, P. O. Box E, Oak Ridge TN 37831

109. M. J. Rohr, DOE/ORO, P. O. Box E, Oak Ridge TN 37831

110. E. E. Hoffman, DOE/ORO, P. O. Box E, Oak Ridge TN 37831

111-210. ORNL Conservation and Renewable Energy Program Office, Building 4500N, Room 141, Mail Stop 188

211-220, Technical Information Center, DOE, P. O. Box 62, Oak Ridge TN 37831 